\title{
عوامل ما وراء المعرفة ودورها في اضطرابات الشخصية لدي طلاب الدراسات العليا بكلية التربية
}

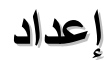

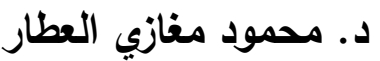 \\ د. قطب عبده خليل حنور

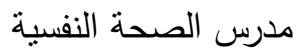 \\ استاذ الصحة النفسية المساعد \\ كلية التربية - جامعة كفر الشيخ
}

DOI : $10.12816 / 0051446$

مجلة الدراسات التربوية والانسانية ـ كلية التربية ـ جامعة دمنهور

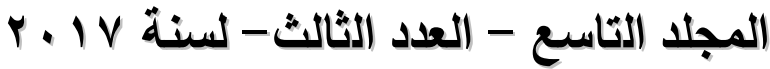


عوامل ما وراء المعرفة ودورها في اضطرابات الشخصية د. قطب عبده خليل حنور د. محمود مغازي العطار 


\section{عوامل ما وراء المعرفة ودورها في اضطرابات الشخصية \\ لاي طلاب الدراسات العليا بكلية التربية \\ د. دمعود مغازي العطار \\ د. قطب عبده خليل حنور}

DOI: $10.12816 / 0051446$

\section{المقدمة:}

تعد مرحلة الدراسـات العليا بمثابة نواة تكوين واستثمار الباحثثن والعلماء في شتي المجالات العلمية، وتمثنل مرحلة الدراسات العليا بكلية التربية أقصي حالات

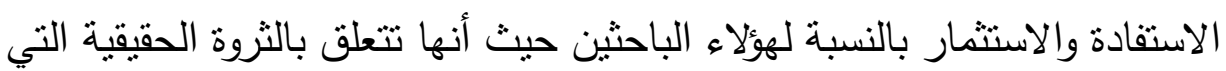

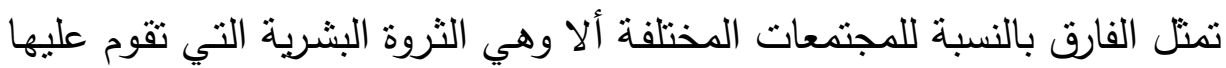
جهود الدراسات العليا في كلية التربية بشكل عام وفي مجال علم النفس والصحة النفسية بشكل خاص.

وتعتبر الثخصية بمثابة أطر عامة شاملة لكل خصائص الثخص في صورة دينامية، فهي تعبر عن جملة الخصائص الجسدية والعقلية والمعرفية والوجدانية

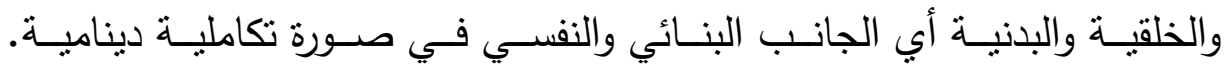

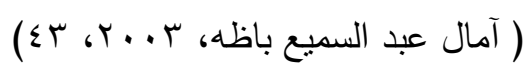
وتنعكس شخصية الفرد علي معاملاتهـ مـع النـاس، فالثخصية هي الصسورة المنظمـة المتكاملـة لسلوك الفرد، التي تميزه عن غيره، أي أنها عاداتهـ وأفكاره

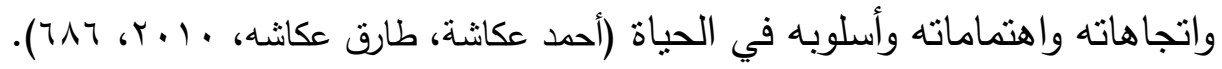

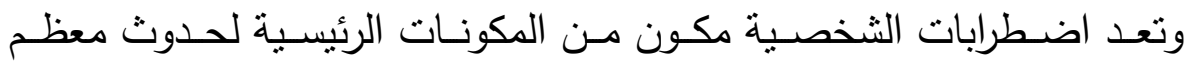
المشكلات النفسية، حيث يعاني الأفراد ذوي اضطرابات الثخصية من صعوبات في التكيف مع الذات والاخرين ويتضح ذلك من خلال وجود متاعب نفسية لدي الفرد بالإضـافة إلي حدوث مشكلات في العلاقـات الاجتماعيـة مـع الآخرين،

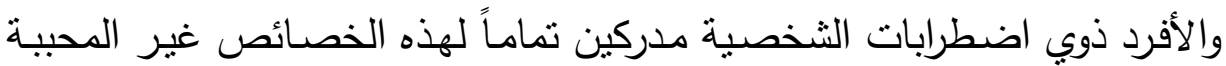


وإلي التأثثر السلبي لهم علي الآخرين ولكنهم يحاولون إعفاء أنفسهم من تحمل المسئولية فهم يرجعون ذللك إلي قلة التقهم والإهتمام من قبل الآخرين مما يؤدي إلي عدم قدرتهم علي تغيير هذه الخصائص. والثخصية المضطربة هي الثخصية التي تتطوي علي خصائص معينة نسبب اضطراب نوافق الفرد مع نفسه أو مع الآخرين، مع شعوره بالمعاناة وعدم السعادة لهية

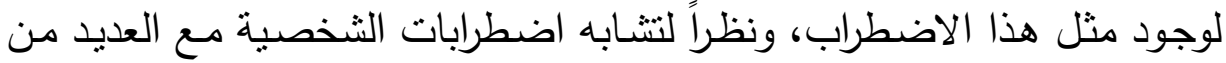

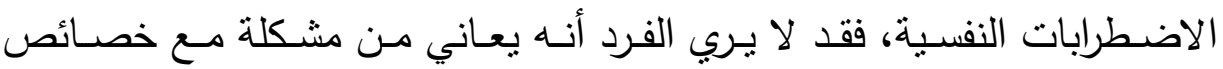

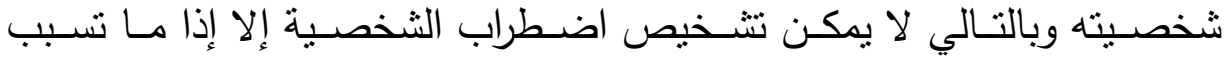

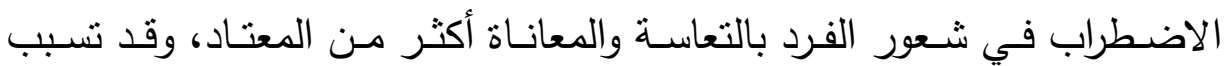

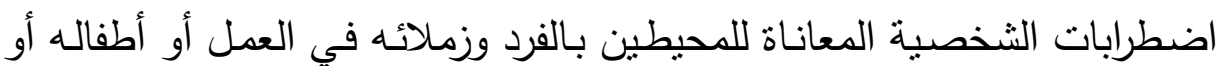
زوجته وما إلي ذللك أكثر ما تسبيه للفرد نفسه.

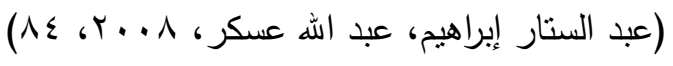

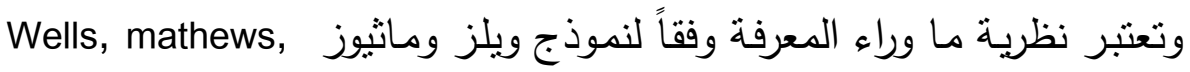
(1994) إحدي النظريـات المعرفيـة التي تفسر الاضطرابات النفسية مـن خـلال التأكيد علي دور عوامل ما وراء المعرفة في نشأة وتكوين الاضطرابات النفسية النافية

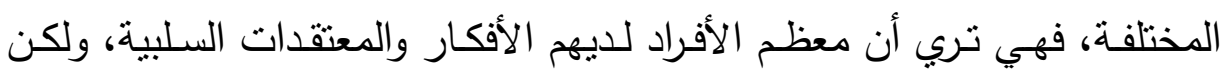
تختلف استجابات بعض الأفراد عن الأفراد الآخرين في طريقة الاستجابة لهذه لهُه

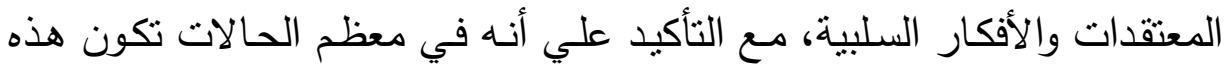
الأفكار والمعتقدات خبرات عقلية عابرة، ولكن في بعض الحالات الأخري تصبح هذه الأفكار والمعتقدات السلبية مشكلة بسبب الطريقة التي يفكر ويستجيب بها الأفراد لهذه الأفكار والمعتقدات السلبية.

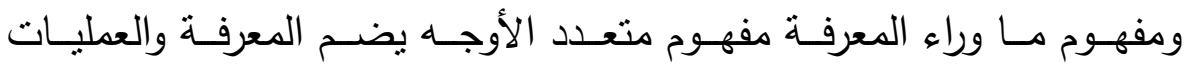
والاستراتيجيات التي تقيم وترصد أو تتحكم في الإدراك، وقد إقترح ويلز وماثيوز

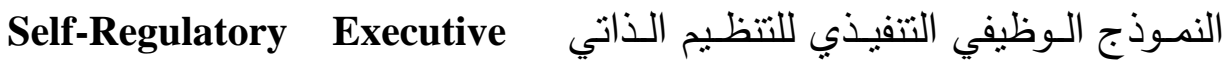




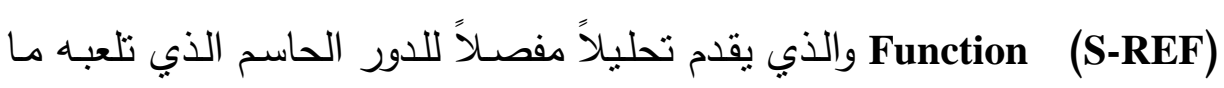
وراء المعرفة في حدوث وتطور الاضطرابات النفسية عن طريق نمط معين يسمي

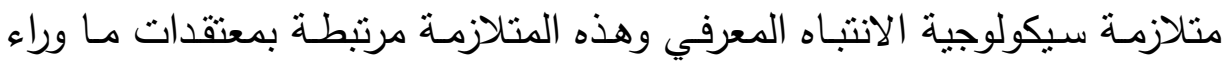

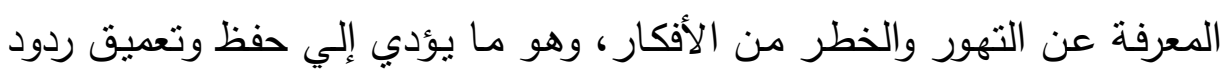

الفعل الانفعالية السلبية مما يؤدي في نهاية المطاف إلي الاضطرابات النفسية. (Valizade, M., et al, 2013, 1555)

ويوفر النموذج الوظيفي التنفيذي للتظيم الذاتي (S-REF) أسـاس لفهم تكرار واستمرار الاضطرابات النفسية حيث ينص النموذج علي أن نمط معين من تكرار التفكير السـام يدعي سيكولوجية الانتباه المعرفي المكتسب (CAS) يسـاهم في لئي تطوير وحفظ وانتكاس الاضطرابات النفسية، وتتألف إستراتيجية الانتباه المعرفي

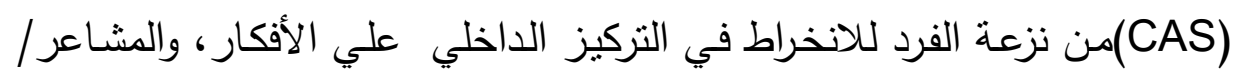

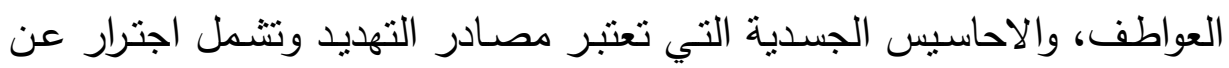

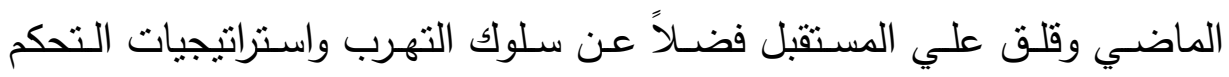
العقلية التي نأتي بنتائج عكسية للمحافظة علي الخلل. (Callesen, P., et al, 2014, 60)

ويعد المفتاح النظري للفكرة التي يقوم عليها ما وراء المعرفة هو أن معالجة ما

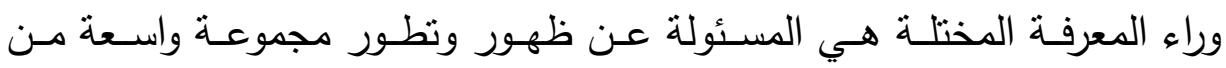

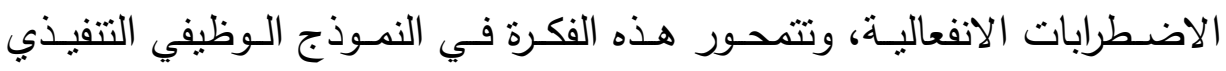
للتنظيم الذاتي (S-REF) الذي قدم بواسطة ويلز ومـاثيوز والذي بـربط بين

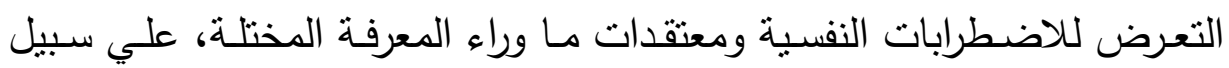
المثال أن القلق لفترة طويلة هو استراتيجية المواجهة الفعالة (Matthews,G., 2015,81) 


\section{مشكلة الدراسة:}

تعد اضطرابات الثخصية بتصنيفاتها المختلفة واحدة من أهم الاضطرابات

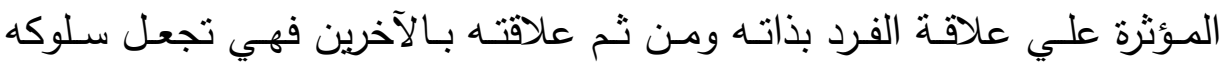

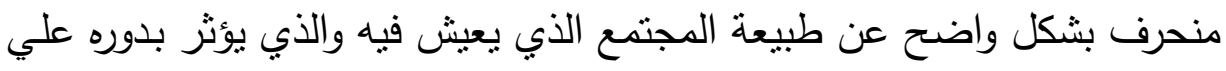

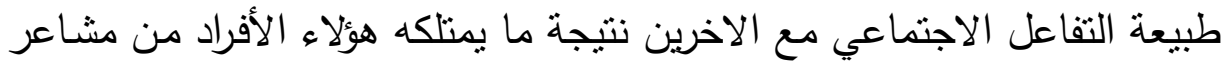

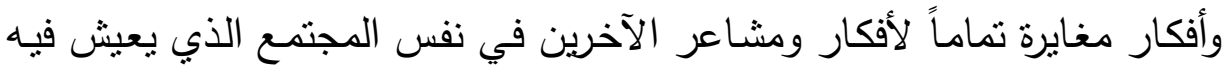
الفرد.

ويقترح نمـوذج مـا وراء المعرفـة ان الاضـطرابات النفسية تـتتج عن التفكير السلبي المتكرر خلال المعتقد المتصور ( علي سبيل المثال. أن العالم خطير) مما يخلق تحيز الانتباه بسبب التركيز المستمر والرصد لهذا المعتقد، لذلك فإن الأثتخاص الذين يعـانون مـن ارتفـاع مستوبي التفكير السلبي المتكرر هـ أقلـل

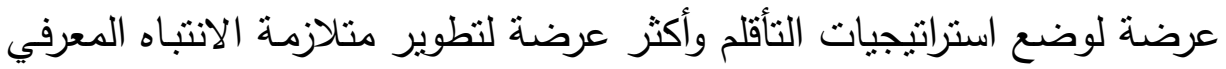
والتي تضم القلق / الاجترار، تهديد ورصد سلوكيات التعامل غير القادرة علي التأقلم، وتكثيف وإطالة أمد المعاناة النفسية. (Wenn, J., et al, 2015, 2) ومـن ثم تحساول الدراسـة الحاليـة دراســة اضـطرابات الثخصـية بتصـنيفاتها المختلفة من خلال منحي جديد إلي حد ما إلا وهو نظرية ما وراء المعرفة وفقاً لنموذج ويلز وماثيوز والذي بدوره يؤكد علي دور عوامل ما وراء المعرفة في نثأة

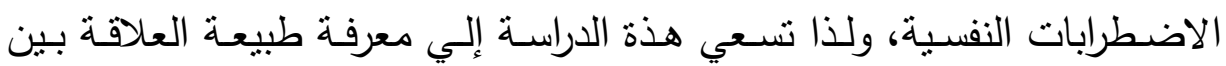

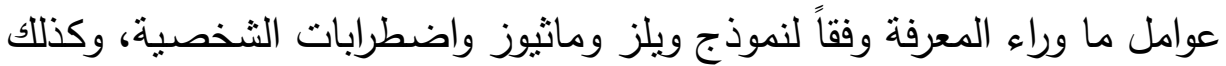
الفروق بين مضطربي وغير مضطربي الثخصية في عوامل ما وراء المعرفة لدي طلاب الدراسات العليا بكلية التربية. 
ولذا يمكن بلورة مشكلة الدراسة الحالية في التساؤلات التالية:

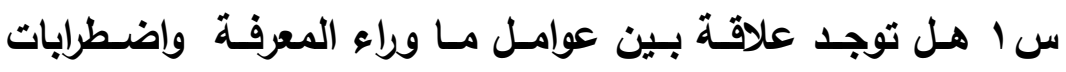

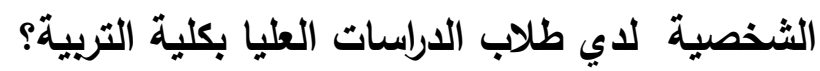

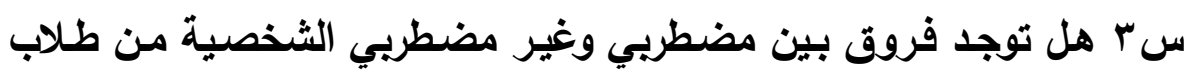

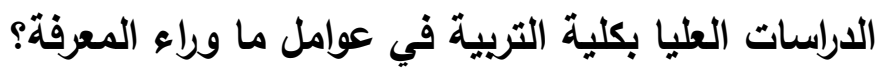

$$
\text { • أهداف الاراسة: }
$$

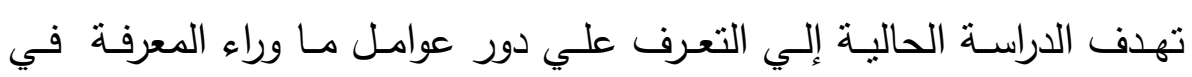

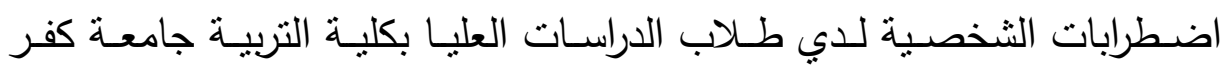
الثيخ. من خـلال الكثف عن العلاقة بين عوامل ما وراء المعرفة واضطرابات الثخصية وكذللك معرفة الفروق بين مضطربي وغير مضطربي الثخصية من طلاب الدراسات العليا بكلية التربية في عوامل ما وراء المعرفة.

$$
\text { • أهمية الدراسة: }
$$

ترجع أهمية الدراسة الحالية من الناحية النظرية إلي النقاط التالية:-

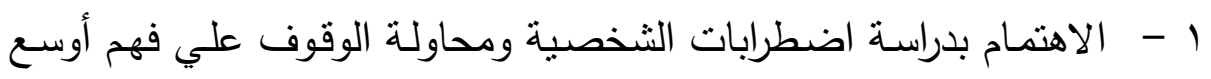

$$
\text { لأسباب نشأة هذه الاضطرابات. }
$$

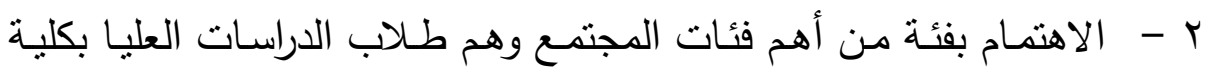
التربية، فهم نواة الباحثين والعلمـاء ويعتمد عليهم في تقدم وتطور هذا

$$
\text { المجتمع. }
$$

r - إمكانية تقديم إطاراً نظرياً جديداً لتفسير اضطرابات الثخصية من خله الكثف عن دور عوامل ما وراء المعرفة في هذه الاضطرابات التي تقدم مدخلاً جديداً لفهم وتفسير اضطرابات الثخصية من خلال نظرية ما وراء

$$
\text { المعرفة. }
$$

أما من الناحية التطبيقية فترجع أهمية هذه الدراسة إلي إمكانية الاستفادة من

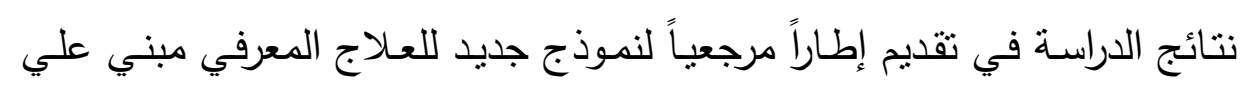


نظريـة مـا وراء المعرفة وعـلاج مـا وراء المعرفـة (MCT) والذي قد يسـاهم في

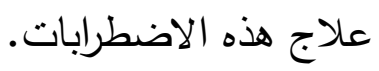
• مصطلحات الدراسة:

\section{أ- اضطرابات الثخصية Personality Disorders}

وتعرف بأنها: نمط ثابت من الخبرة الداخلية وسلوك منحرف بشكل واضح عن الثقافة التي يعيش فيها الفرد ويظهر هذا النمط في اثثين أو أكثر مـن بن الجوانب الآتية: المعرفة والوجدان واضطراب علاقة الفرد بـالآخرين، عدم القدرة

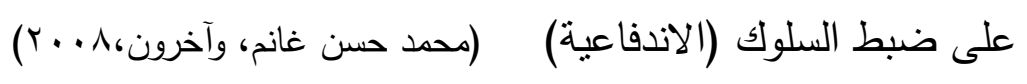

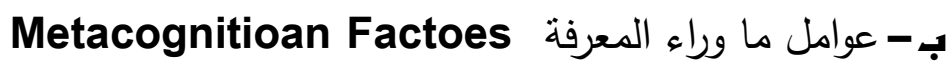

هي مجموعـة مـن العوامل التي تشتمل علي العمليـات والمعتقدات المرتبطـة باحتمال أن تكون سبباً معرفياً لوجود واستبقاء الاضطرابات النفسية وتشمل علي لهي خمس عوامل هي (المعتقدات الإيجابية نحو الهم أو الانزعاج- المعتقدات السلبية

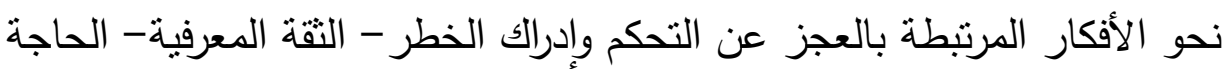

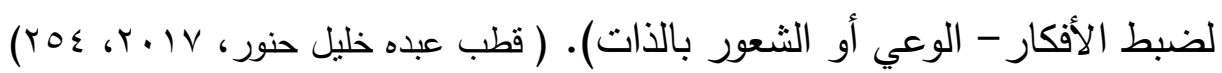
الإطار النظري:

أولاً: عوامل ما وراء المعرفة: الإطي: Metacognition Factors قدم الباحثون تعريفات مختلفة لما وراء المعرفة، وقد استخدم مصطلح ما وراء المعرفة في البداية من قبل Flovel وعرفها بأنها التفكير في التفكير وفي السنوات

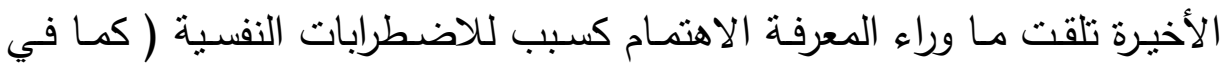
نمـوذج ويلز ومـاثيوز )، ويتعلق مـا وراء المعرفـة بالمشـاركة في التقيهم والمراقبـة

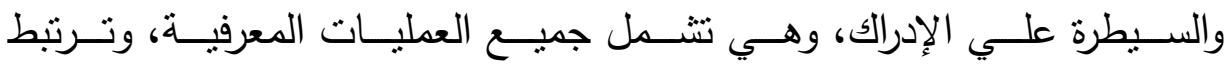
الاضطرابات النفسية ببعض الجوانب المحددة في ما وراء المعرفة، ووفقاً لنظرية وهنية ما وراء المعرفة فإن معتقدات ما وراء المعرفة توجه الانتباه وتحدد أسلوب التفكير وتؤدي إلي استجابات التكيف التي تتسبب في إنتاج المعلومـات غير المفيدة، 
وتشير النظرية أيضـاً إلي وجود معتقدات ما وراء المعرفة إلي جانب المعتقدات

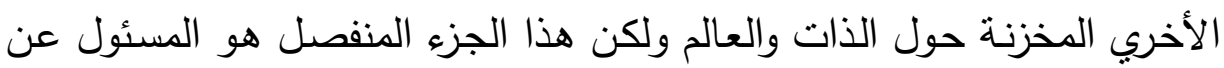
السيطرة علي الإدراك واستخدام المعتقدات والمعارف الأخري، واستتاداً إلي نظرية

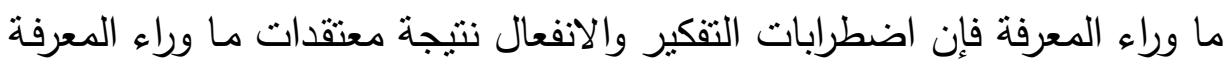

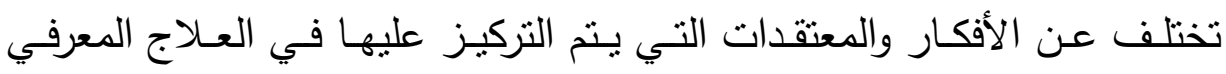

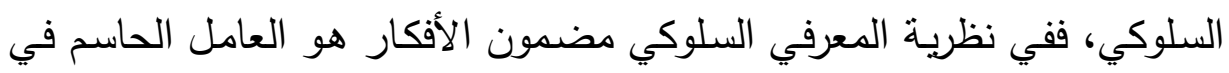

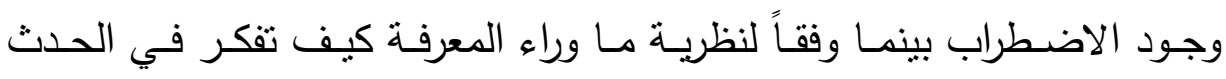

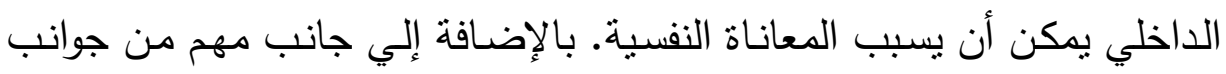

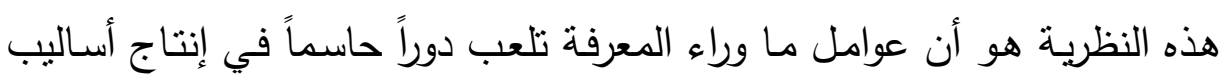

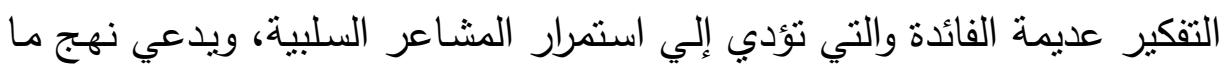

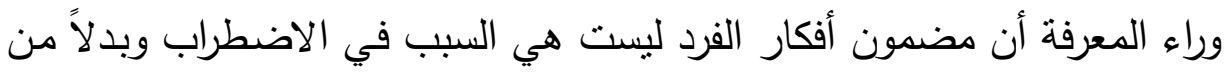
ذلك يرتبط السبب بمعتقدات ما وراء المعرفة التي شكلت أساليب التفكير . (Moghadam, N. S., et al, 2014, 1663) وتعتبر نظرية ما وراء المعرفة للاضطراب النفسي وفقاً لنموذج ويلز هي النهج

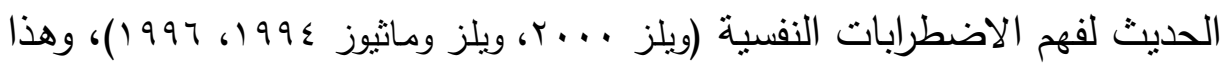

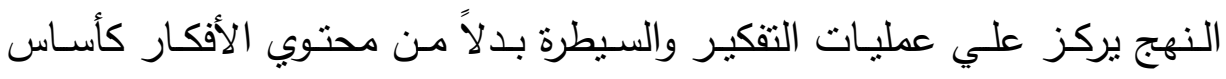
لتطوير الاضطرابات النفسية. ويشير مصطلح ما وراء المعرفة إلي مستوي معرفة بهرية أعلي وهو مسنوي العمليات التي تتطوي علي القدرة علي رصد ومراقبة وتقيهيم

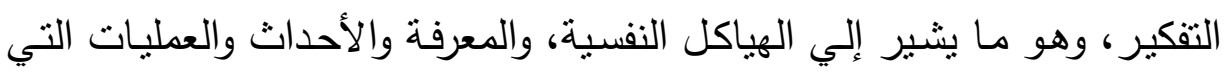

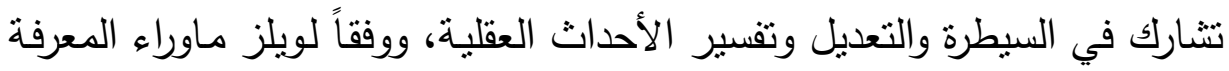

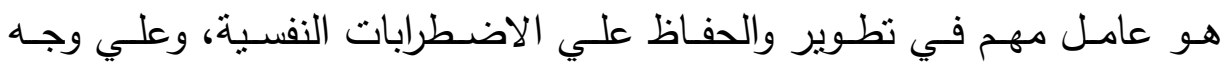

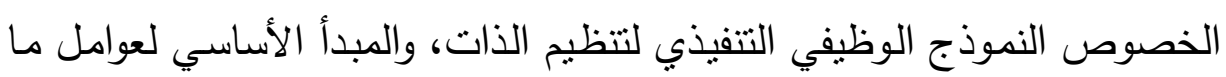

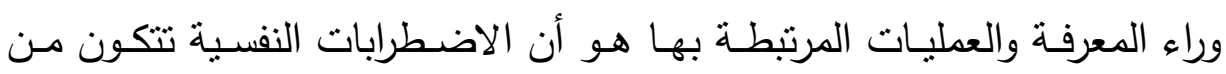


مكون مـا وراء المعرفـة الذب يوجـه نشـاط التفكير والتكيف، ويؤدي إلي أنماط موسعة ومثابرة من التفكير الذي يسبب الاضطراب. (Hjemdal, O., et al, 2013, 60)

ويُعد الأساس النظري لما وراء المعرفة هو النموذج الوظيفي التنفيذي للنتظيم الذاتي Regulatory Executive Function(S-REF) الذي يؤكد علي أوجهـ

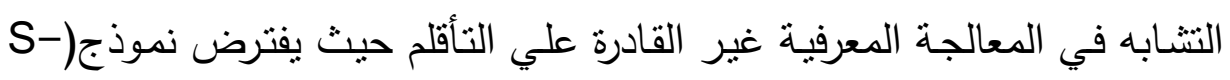
Cognitive (CAS) أسلوب تفكير يسمي متلازمـة الانتباه المعرفي (REF Attention Syndrome

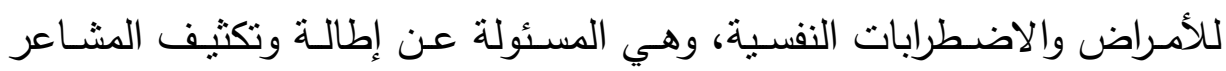

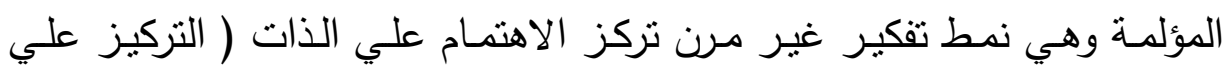

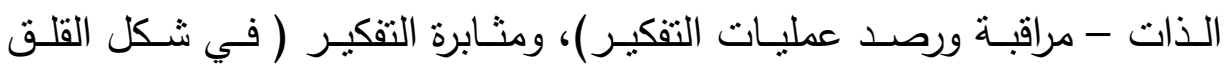

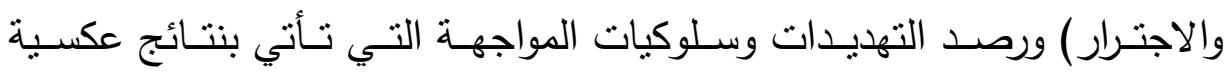
وتتداخل مع السيطرة العقلية الفعالة، وتعلم التكيف، وتعتبر (CAS) مشكلة لانها تحافظ علي معالجة نركز علي التهديد والفتشل في توفير المعلومات التي يمكن أن أن

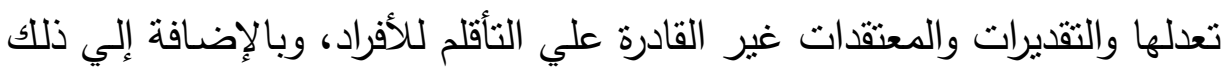
تستخدم (CAS) كإستراتيجية مساعدة في الانتباه إلا أنها توجه نحو الاستجابات

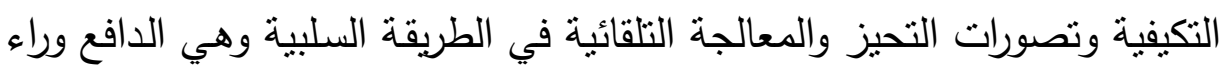

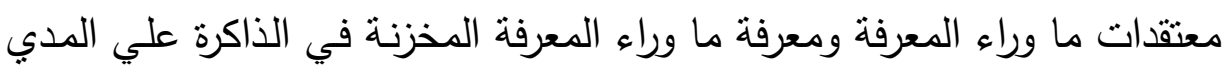
(Hjemdal, O., et al, 2013, 301-302) الطويل. ويقترح نموذج (S-REF) أن معتقدات ما وراء المعرفة تتألف من اثتين من المكونـات والتـي توجـه معالجـة المعلومـات والتفسيرات والسـيطرة علـي الأفكـار وهما:-

أولاً: معرفة ما وراء المعرفة أو المعتقدات الإيجابية والسلبية التي يحملها الفرد حول كيفية تتظيم الحالات الداخلية. 
ثُانبـاً: نتظيم مـا وراء المعرفـة أو الاسـتراتيجيات والتغيرات التي نركز علي

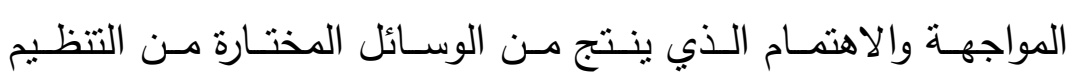

$$
\text { الداخلي. (Vann, A., 2013, 2) }
$$

ففي نظريـة مـا وراء المعرفـة للاضطرابات النفسية قد يعاني الفرد من خلـ وظيفي ولكن مجرد حدوث الفكرة لن يؤدي إلي الاضطراب بل كيف يستجيب

$$
\text { الفرد إلي الفكرة هو الذي يحدد حدوث الاضطراب النفسي. }
$$

(Huntley, C. D. \& Fisher, P. L, 2016, 446)

واقترح ويلز وماثيوز أن المعنقدات والأفكار السلبية والأعراض النفسية شائعة .

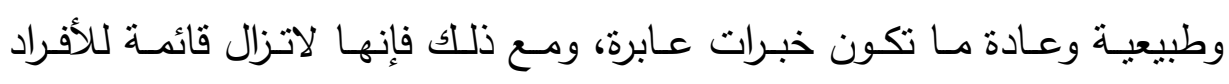

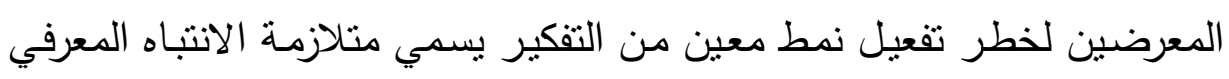

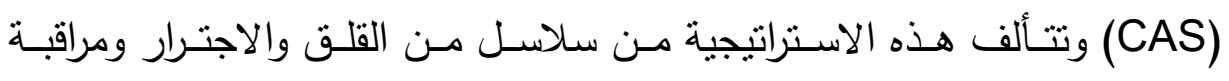

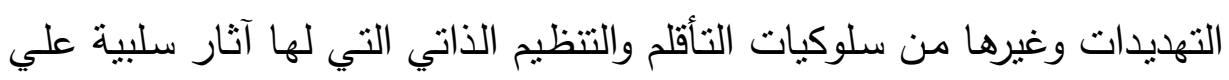
تتظيم العاطفة، المشكلة أنها مع هذه الردود تمتند إلي التفكير السلبي مما يؤدي

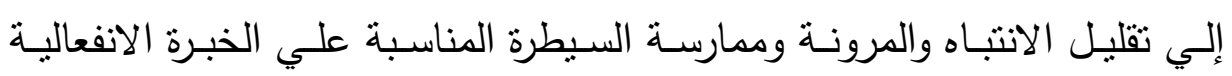
السلبية. البية ) (Wells, A., et al, 2012, 367) ويشير ما وراء المعرفة إلي أن جميع الاضطرابات ترتبط بمستوي أعلي من

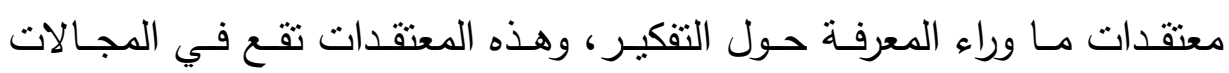

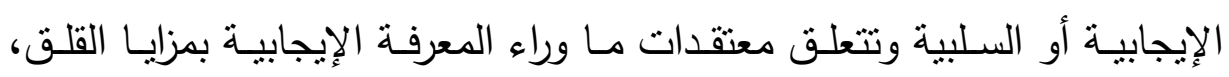

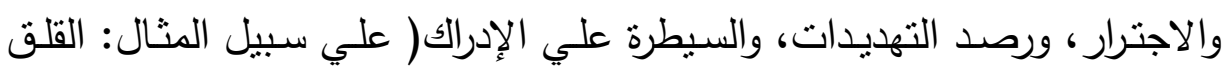

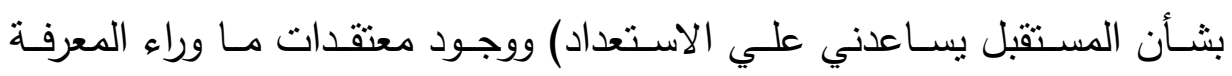

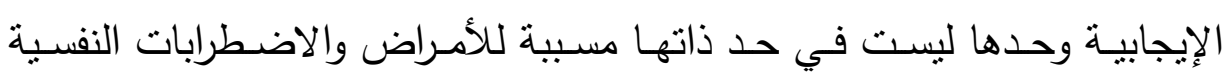

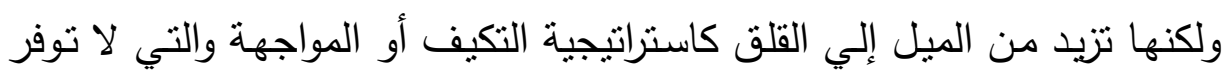

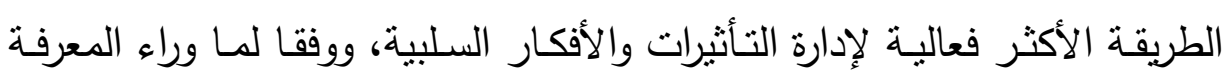
الأمراض والاضطرابات النفسية تتطور عندما يتم تتشيط معتقدات ما وراء المعرفة 
السـلبية حـول السـيطرة والخطـر ، وهـذه المعتقدات تتعلـق بعدم السيطرة علي

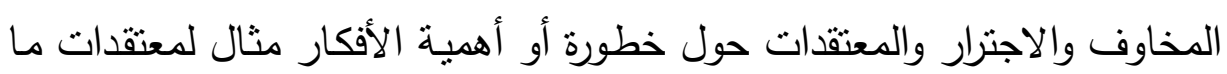
وراء المعرفة السلبية " قلقي خارج نطاق السيطرة وسوف يجعلني أفقد عقلي" وهو مـا يؤدي إلي استخدام أثنكال غير مفيدة مـن السيطرة أو عدم السيطرة علي ليطي الإطلاق. (Hjemdal, O., et al, 2013, 302)

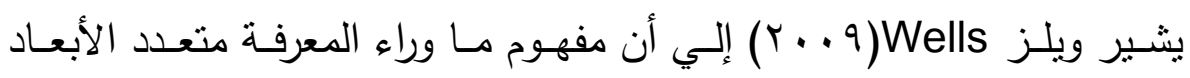

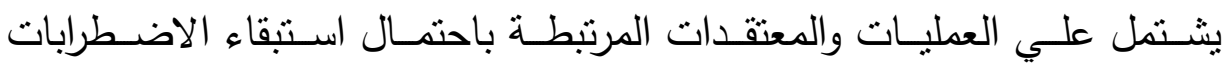

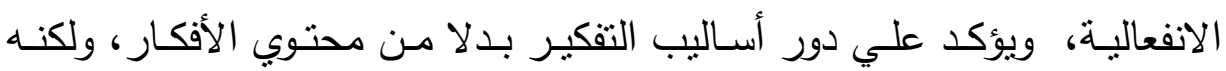

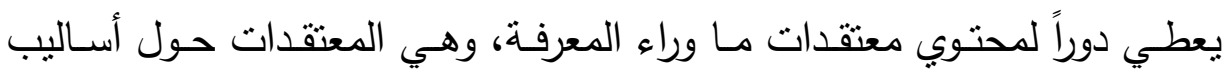
التفكير وهي:-

1 - المعتقدات الإيجابية حول القلق: وتقيس مدي اعتقاد الثخص بأن اجترار

$$
\text { التقكير مفيد. }
$$

r - المعتقدات السلبية حول أفكار عدم السيطرة والخطر : وتقيم مدي اعتقاد الفرد بأن اجترار الأفكار لا يمكن السيطرة عليها أو خطورتها. r - الاثتقار إلي الثقة المعرفية: وتقيم الثقة في الانتباه والذاكرة.

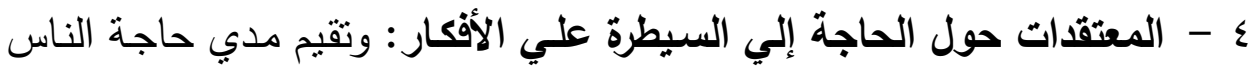

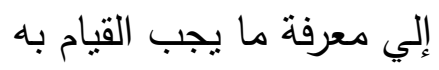

ه - الـوعي الـاتي الإدراكي: ويقيس الميل إلي رصد الأفكار الخاصـة وتركيز

$$
\text { الانتباه إلي الداخل. }
$$

(Maher-Edwards, L., et al, 2011, 312)

\section{ثانياً: اضطرابات الثخصية Personality Disorders}

وتعرف اضطرابات الثخصية وفقا للاليل التشخيصي والإحصائي الخامس بأنها: نمط دائم من الخبرة الداخلية والسلوك الذي ينحرف بشكل ملحوظ عن توقعات ثقافة الفرد وهو منتشر، وغير مرن، لديه بداية في مرحلة 
المراهقة أو مرحلة البلوغ المبكر ، وهو يستقر مع مرور الوقت ويؤدي إلي الضيق (A.P.A., 2013, 645) أو الضعف. معايير اضطرابات الشخصية عامة:--

أ- نمط دائم من الخبرة الداخلية والسلوك الذي ينحرف بشكل ملحهوبات عن عن توقعات

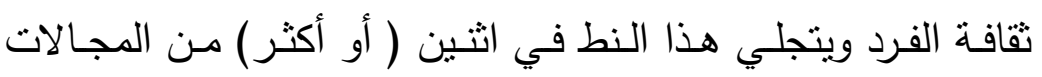
التالية:-

1- الإدراك ( أبي طـــرق إدراك وتقفــير الــذات، والأشـــاص الآخــرين،

$$
\text { والأحداث) }
$$

r- الوجدان ( أي المدي، والثدة، والتوتر ، وملائمة الاستجابة العاطفية)

$$
\text { ع - السيطرة علي الأداء بين الاتخاص الاصعالات }
$$

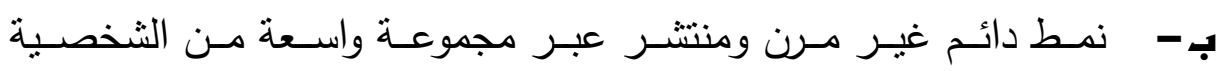

$$
\text { والأوضاع الاجتماعية }
$$

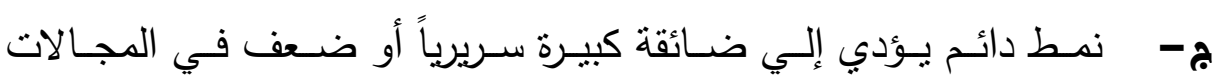
الاجتماعية والمهنية أو غيرها من مجالات الأداء الهامة

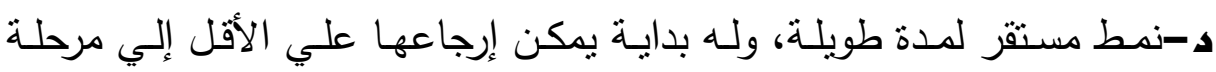

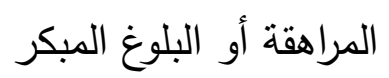

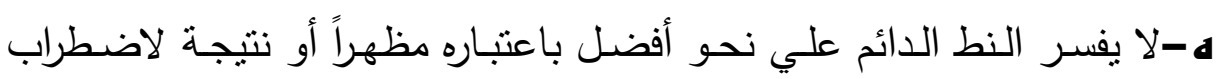

$$
\text { عقلي آخر }
$$

و - لا يعزي النمط الدائم إلي التأثنرات الفسيولوجية للمادة ( علي سبيل المثال،

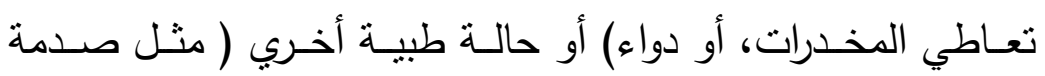

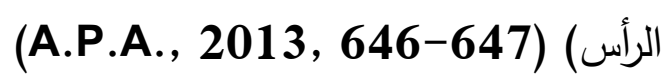


وتثثمل اضطرابات الثخصية وفقاً للمقياس المستخدم في الدراسة ما يلي:-

1- الثخصية البارانويدية: هو اضطراب في الثخصية، يتميز بحساسية مفرطة

نحو الهزائم والرفض وعدم مغفرة الإهانات والجروح، وميل نحو حمل الضغائن

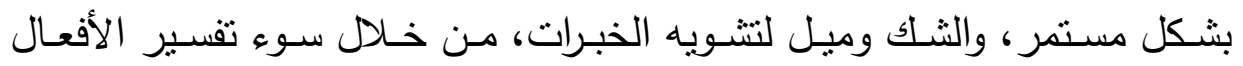

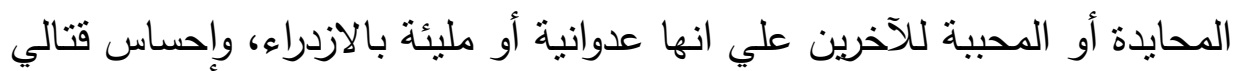
وتتتـبث بـالحقوق الثخصـية غير منتاسب مـع الموقف الفعلي وقابليـة للغيـرة المرضية وميل إلي الإحساس بأهمية ذاتية مفرطة وفي كثير من الأحوال إحساس

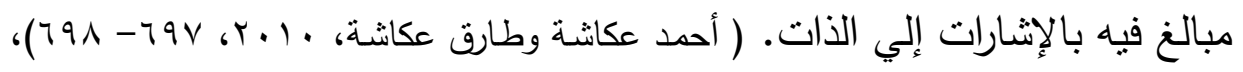
وهو نمط من انعدام الثقة المنتشر وارتياب من الآخرين بحيث يتم تفسير دوافعهم

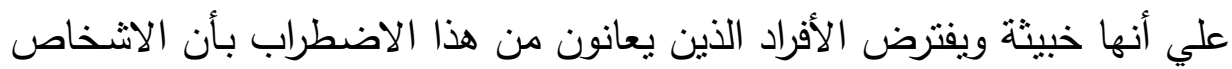

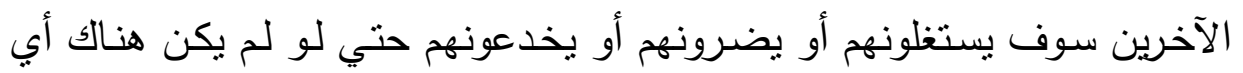

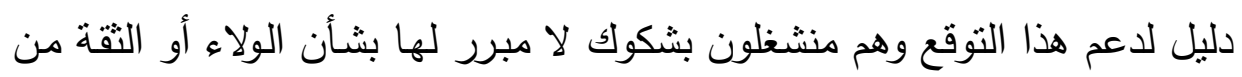
(A.P.A., 2013, 649-650)

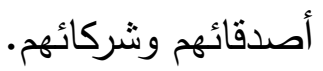
r - الثخصية الفصامية:

هو اضطراب شخصية ينسم بالعزوف عن الآخرين والعمل مفرداً وعدم الانشغال بـالأمور المعيشية وعدم الاهتمـام بنظرة الآخرين إلي مـع تفضيله

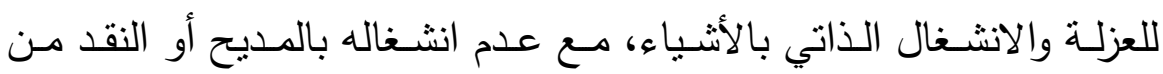

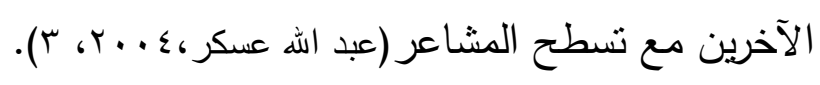
r- الثخصية الثبه فصامية:

هو اضـطراب شخصـية يتميز : بـالانعزال عـن المجـالات التي تتضـمن

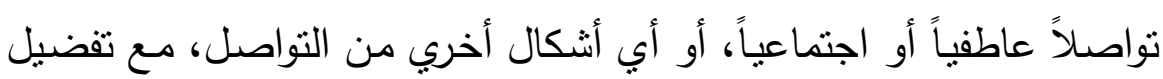

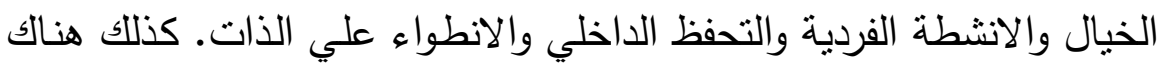

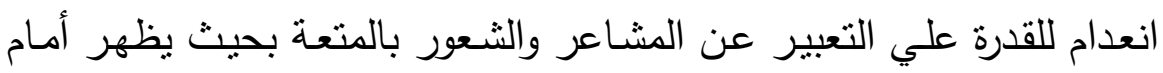

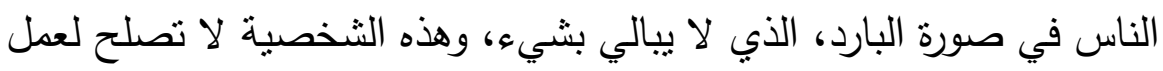

DOI: $10.12816 / 0051446$ 
يحتلك فيه بالجماهير ، مثل الخطابة، التمثيل، أو العلاقات العامة حيث يعجز

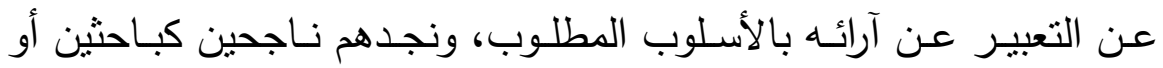

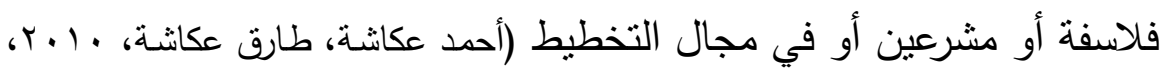

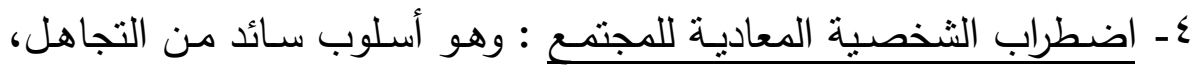

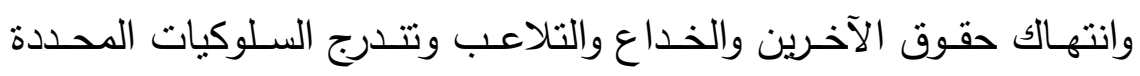

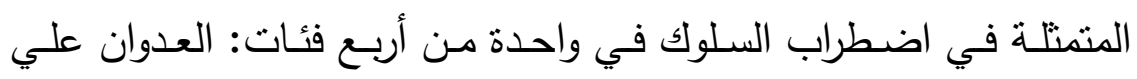

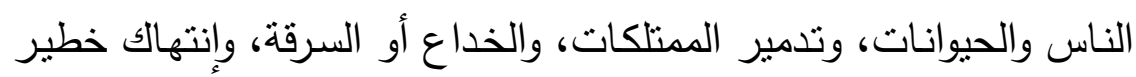
للقواعد. (A.P.A., 2013, 659) 0- اضطراب الثخصية البينية: وهو اضطراب في الثخصية يتميز بالتقلب

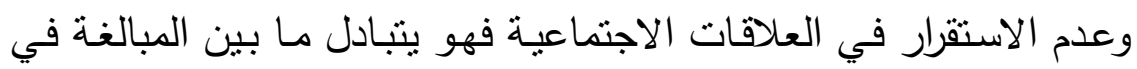
الاعجاب والتقدير إلي المبالغة في الاحتقار والتقليل من قيمة الاشخاص، لهاصل

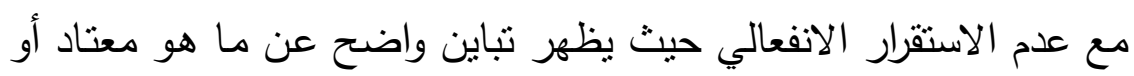

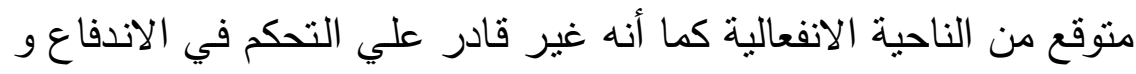
الغضب، بالإضافة إلي التهديد بالانتحار أو التظاهر بمحاولة القيام بـه أو الو الته

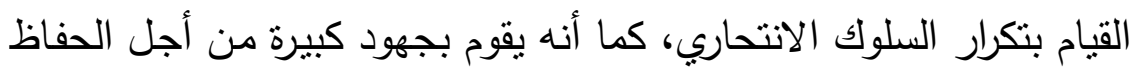

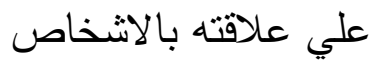
ا- اضطراب الثخصية الهيتيرية: وهو اضطراب في الثخصية يتميز بمبالغة

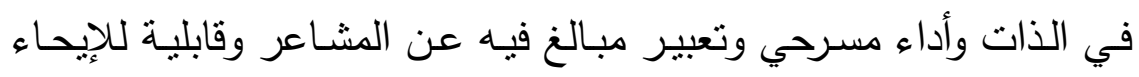

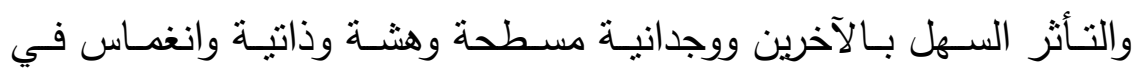

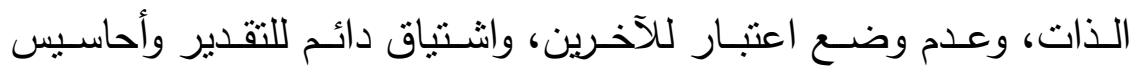
بسهولة الإيلام والنهم للإثارة والنشاطات التي يكون هو أو هي في فيها مركزا للانتباه، وسلوك ابتزازي دائم للوصول إلى الأغراض الذاتية

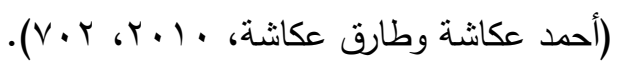


V- اضطراب الثخصية النرجسية: هو نمط سائد يتصف بالثعور بـالخيلاء،

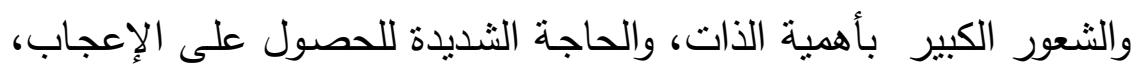

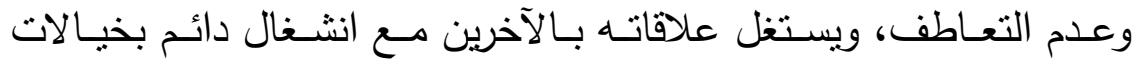
النجـاح الذي لا يعرف أي حدود ، والمبالغـة في تقدير قدراته وتضـخيم إنجازاته مع تقليل مساهمات الآخرين.

^ــ اضـطراب الثخصـية الوسواسـية القهريـة: نمـط شـامل يصـيب الثخصـية

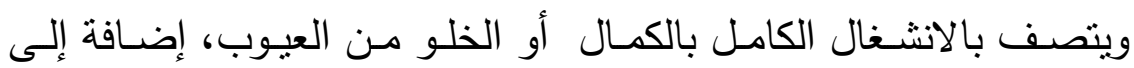
التركز على التفاصيل، وعدم المرونـة ممـا يفســ علاقاتهم الاجتماعيـة،

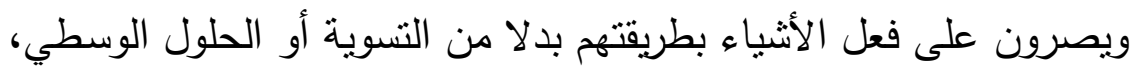

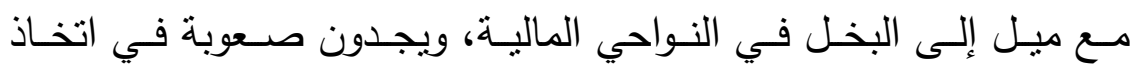
القرارات، وأن علاقاتهم بالآخرين تكون رسمية، مع صعوبة في التعبير عن

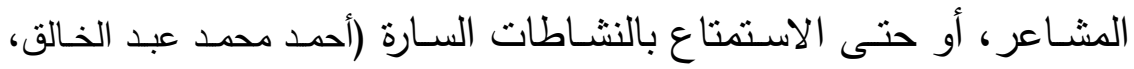
. ros-ror ص r...r 9- اضطراب الثخصية التجنيية: اضطراب شخصية يتميز بأحاسيس مستمرة وواسـعة المــى بـالتوتر والتـوجس واعتيـاد على الـوعي الثـديد بالـذات

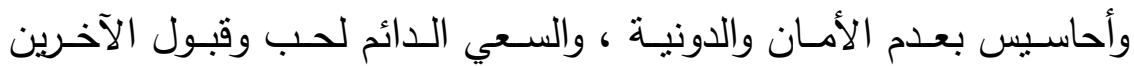
وحساسية مفرطة نحو الرفض والنقد، ورفض الدخول في أي علاقات إلان والا ولان بعد الحصول على ضمانات شديدة بالقبول غير المشروط بنقد، وارتباطات

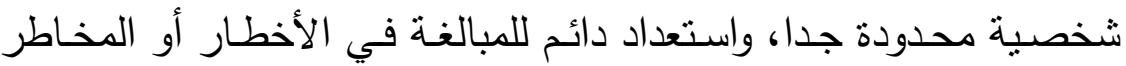
المحتملة في المواقف اليومية، إلي حد تجنب بعض النشـاطات المعنية، ولكن ليس إلي حد التجنب الموجود في الرهـاب، وأسلوب حيـاة محدود

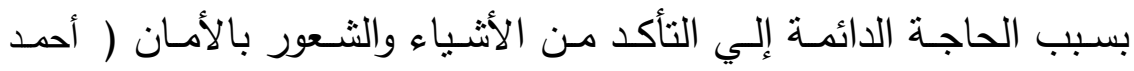

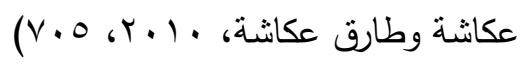


• (-اضطراب الثخصية الاعتماديـة: هو نمط سـائد في الثخصية يتصف

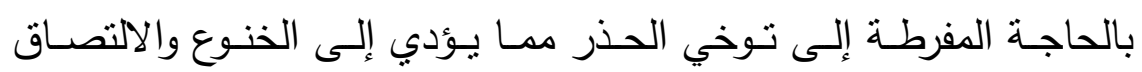

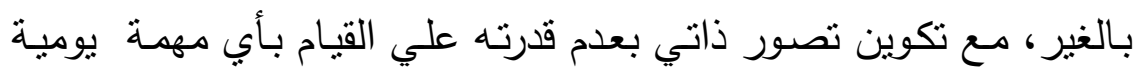

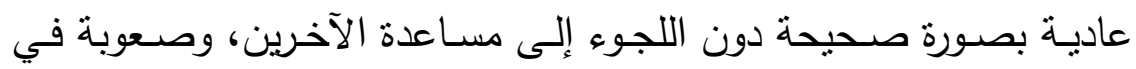
التعبير عن اختلافات الرأي مع الآخرين، وكذا صعوبة بالغة في القوة القيام بأي

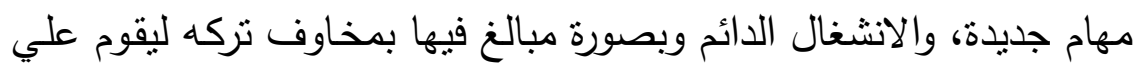
رعاية نفسه دون العون والمساعدة من قبل الآخرين.

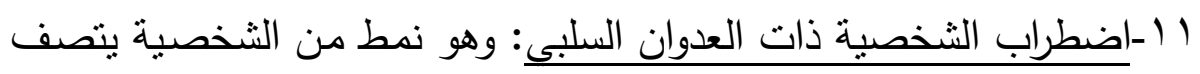

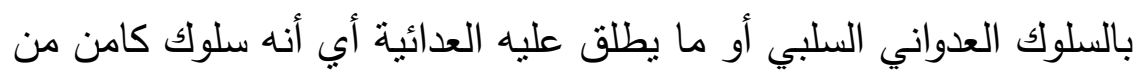

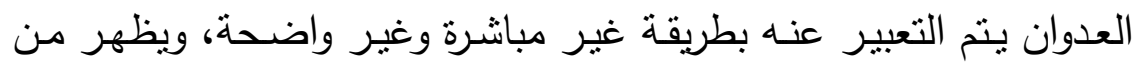

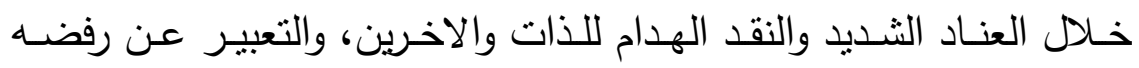
بطرق سلبية مثل رفض تتاول الطعام والتظاهر بعدم الفهم وتتفيذ عكس ما يطلب منه. r (-اضطراب الثخصية الاكتئابية: هو نمط سائد في الثخصية يتسم بطابع

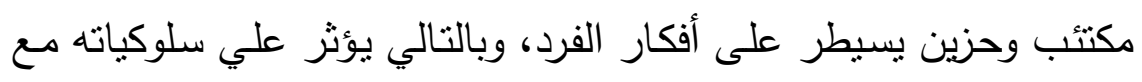

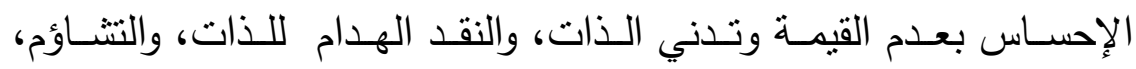

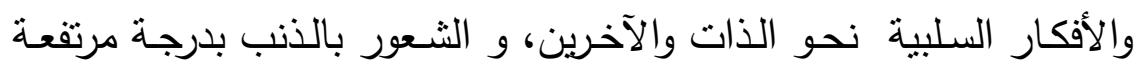
وغير واقعية.

א ا-اضطراب الثخصية الهازمـة للذات: وهو اضطراب في الثخصية يتميز

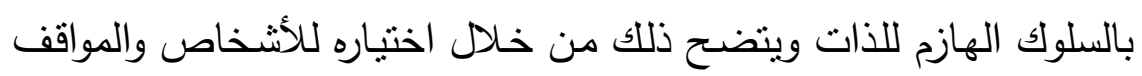
التي تؤكد له هذا الثعور فهو يسعي لما يسبب له الثعور بالفشل والاحباط

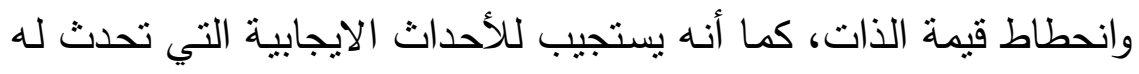

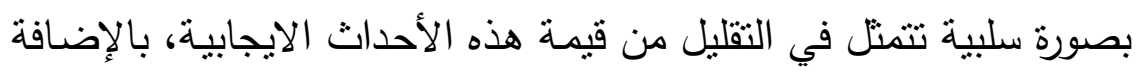

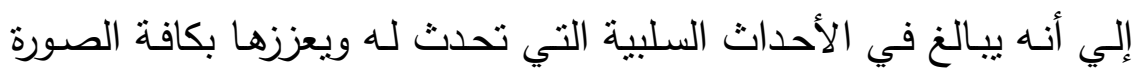


المتاحة له، وتعد الهزيمة الذاتية اكثر ضرر وخطورة علي الفرد من محاولة

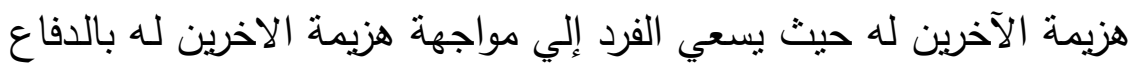
عن نفسه بينما لا يحدث ذللك في حالة هزيمته لذاته. ع (-اضطراب الثخصية السادية: نمط متأصل في الشخصية يتصف باشتقاق هئ اللذة عن طريق القيام بتعذيب الآخرين، سواء بتوجيه عدوان مادي إليهم بـانه

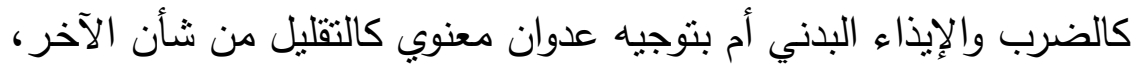

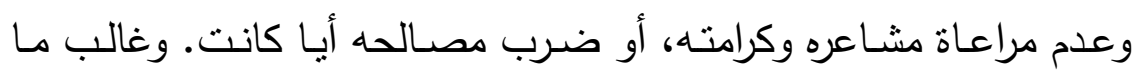

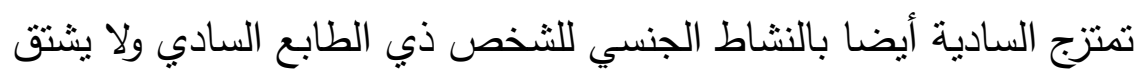

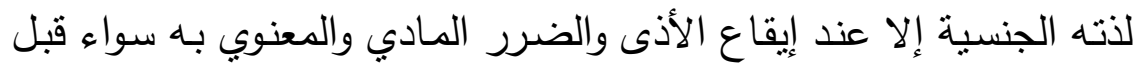

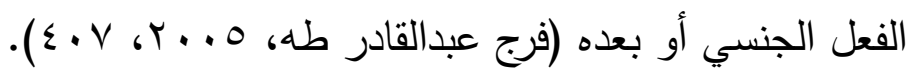
1 ا-اضطراب الثخصية المازوخيـة: هو نمط من الثخصية ينم فيه اثنتقاق الفرد للذة من قيام الآخرين بتعذيبه وتوجيه العدوان إليه، سواء أكان عدوانا ماديا أو معنويا كتحقير الفرد وإهانته وجرح كرامته والسخرية منه وإظهار

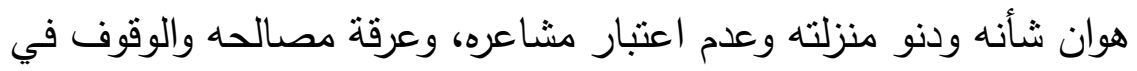

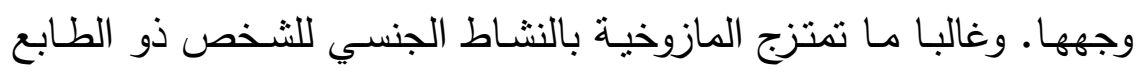

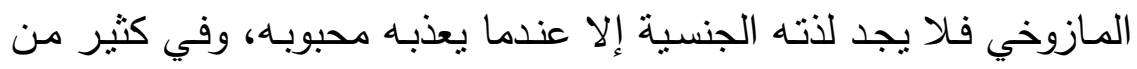

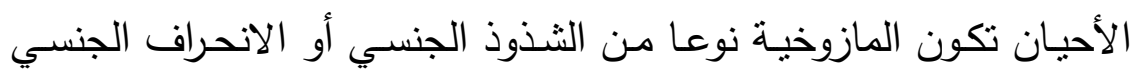

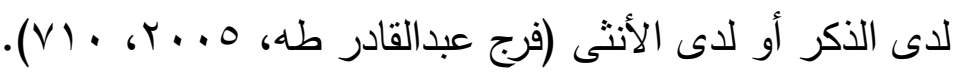

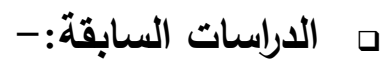

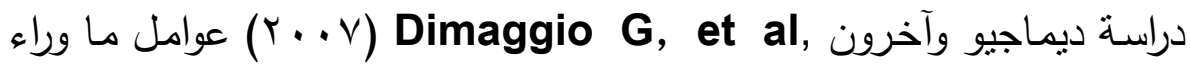
المعرفـة لدي اضطرابات الثخصـية النرجسبة والانطوائيسة أثنـاء عمليـة العـلاج

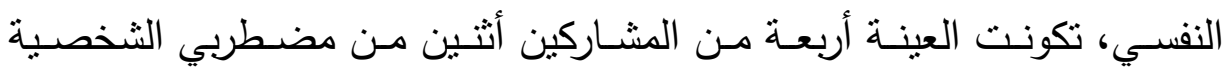

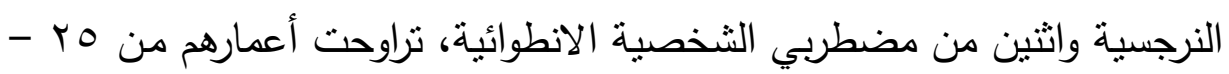
• ع عاماً، أظهرت النتائج ثلاثة من الحالات الاربعة لديهم اضطراب في عوامل 
مـا وراء المعرفـة (اثثين مـن مضطربي الثخصسية النرجسية وحالـة مضطربي الانطواء).

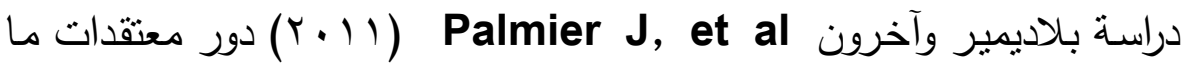
وراء المعرفة في الحساسية للضغوط وتقدير الذات ونشأت البارانويا، تكونت العينة

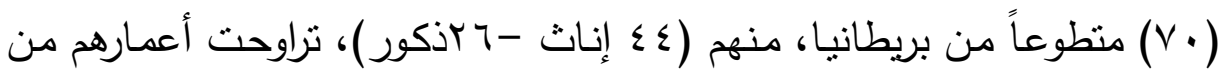

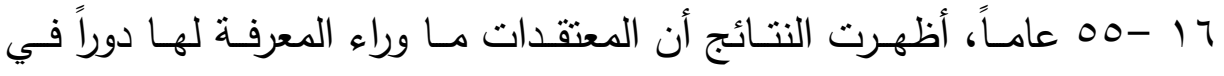

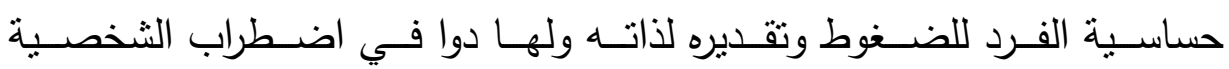
البارانويدية.

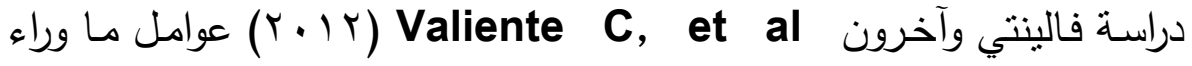
المعرفـة والحالة النفسية لدي اضطراب الثخصية الاكتئابية والفصـامية، تكونت

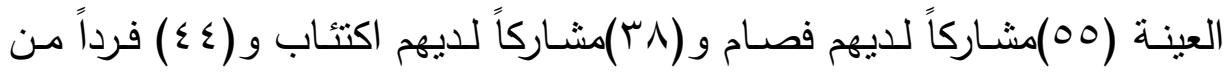

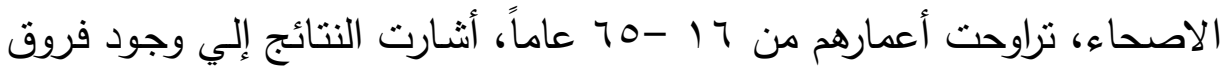

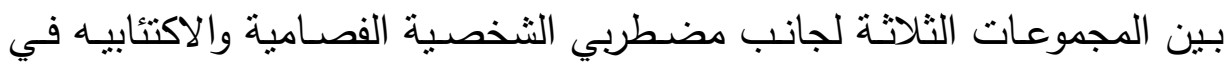
عوامل ما وراء المعرفة (المعتقدات السلبية نحو الأفكار المرتبطة بالعجز -التقة المعرفية - الحاجة لضبط الأفكار) عن الاصحاء، وأن وجود فروق بين مضطربي الصني الثخصية الفصامية والاكتئابيه لصالح الاكتئابية في عوامل ما وراء المعرفة.

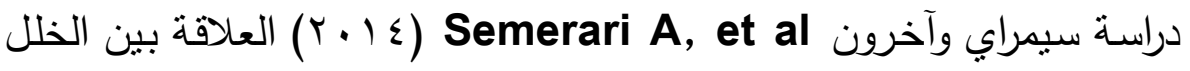

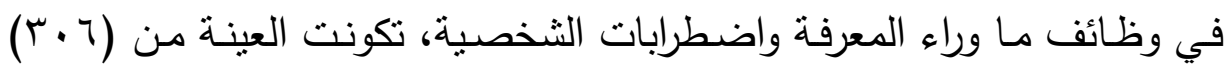
فرداً منهم (919 (1) لديهم اضطرابات شخصية و (1 • (1) ليس لديهم اضطرابات

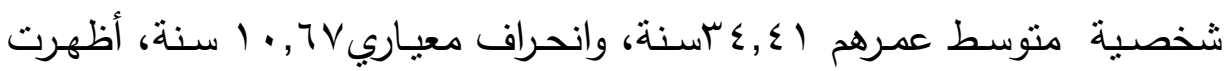
النتائج وجود ارتباط موجب بين عوامل ما وراء المعرفة واضطرابات الثخصية، ووجود فروق بين المجموعتين في خلل عوامل ما وراء المعرفة لجانب مضطربي 
دراسة اوتكالت وآخرون Outcalt J, et al (T ( • إ) العلاقة بين ما وراء المعرفـة واضطراب الثخصية الحديـة لدي الاثـخاص المعـالجون مـن الادمـان،

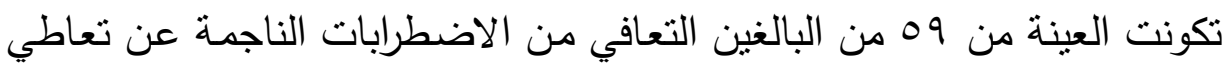

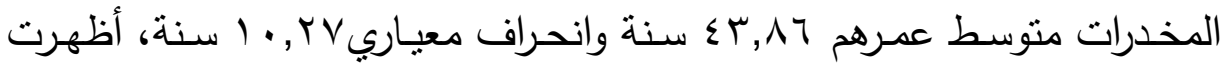
النتائج وجود ارتباط موجب بين عوامل ما وراء المعرفة واضطراب الثخصية الحدية.

$$
\text { ه أدوات الدراسة }
$$

أ- مقياس ما وراء المعرفة (MCQ-30)

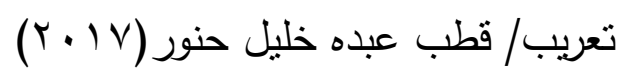

هو نسخة مختصرة تتكون من · ب بنداً طُور من قبل ويلز وكارترايت - هاتون Wells, A., \& Cartwright-Hatton, S لمـا وراء المعرفـة، ويستتند على التصـور النظـري الذي تقدمـه نظريـة الوظيفـة التنفيذية لتنظيم الذات. وهناك خمسة عوامل يتضمنها المقياس تقيس عوامل ما وراء المعرفة وهي على النحو التالي:

1 بـأن الهم والانزعـاج يسـاعد على حل المشكلات وتجنب المواقف غير

$$
\text { السارة. }
$$

r - المعتقدات السلبية نحو الأفكار المرتبطة بالعجز عن التحكم وإدراك الخطر:

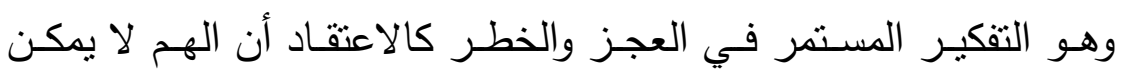
السيطرة عليه، مما ينتج عنه مخاطر عقلية وعضوية. ب - الثقـة المعرفيـة: وهـي المـدي الذي يظهـره الفرد مـن عدم الثقـة في ذاكرتهـ وانتباهه. ع - الحاجة لضبط الأفكار : وهي المعتقدات التي تتعلق بضرورة قـع الأفكار أو تجنبها والسيطرة عليها. 
ه - الوعي أو الثعور بالذات: وهو الميل لمراقبة وتقيم الأفكار وتركيز الانتباه للاخل. قام معدا المقياس بحساب صدق المقياس باستخدام الصدق التلازمي والصدق

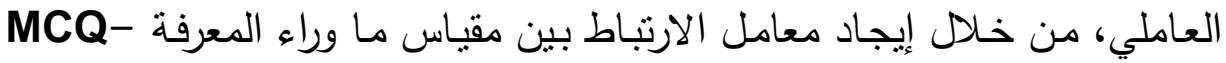

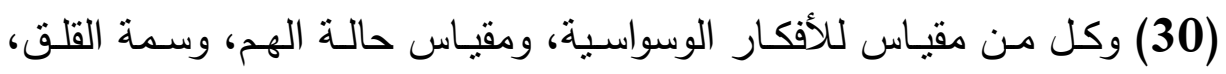

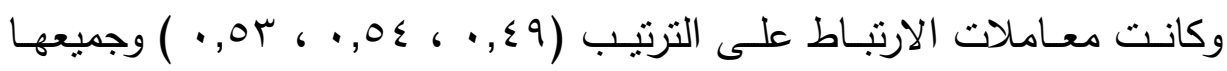

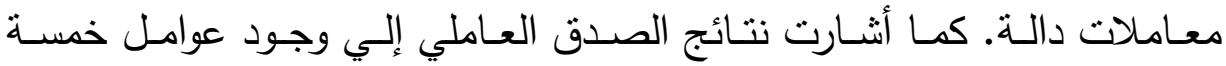

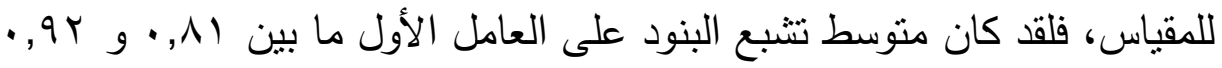

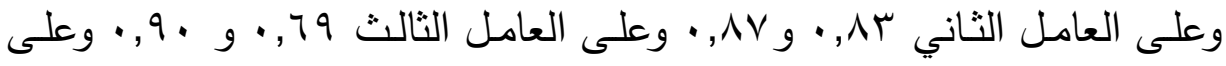

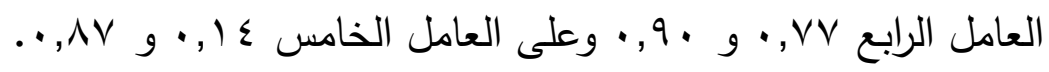

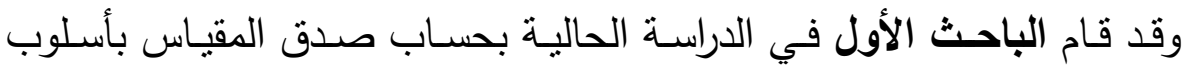

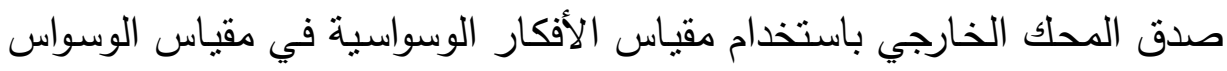

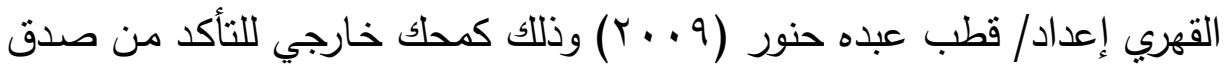
المقياس وصلاحيته كأداة تشخيصية، وذللك من خلال حساب معامل الارتباط بين

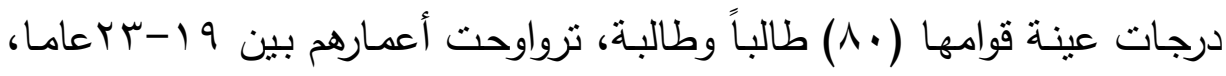
من طلاب كلية التربية جامعة-كفر الثيخ على المقياسين. وكان معامل الارتباط

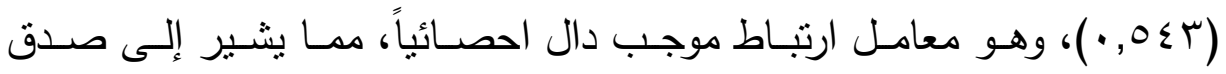
المقياسين. وقام معدا المقياس بحساب الثبات باستخدام معامل ثبات ألفا-كروباخ وإعادة

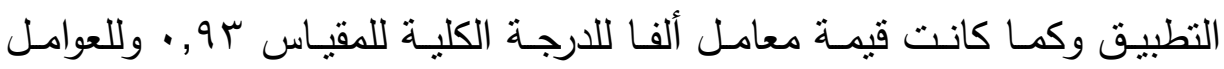

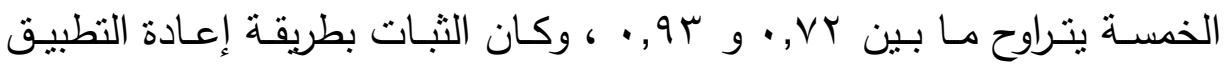

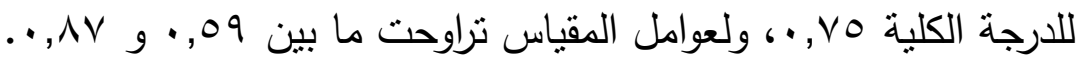
وقد قام الباحث الأول في الدراسة الحالية بحساب ثبات المقياس بطريقة إعادة

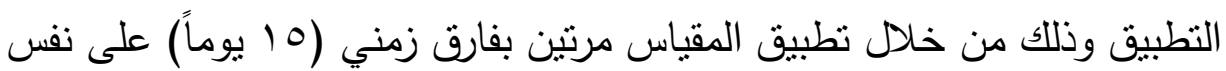


عينـة الصـدق، وإيجـاد معامـل الارتبـاط باسـتخدام معامـل ارتبـاط بيرسـون بين

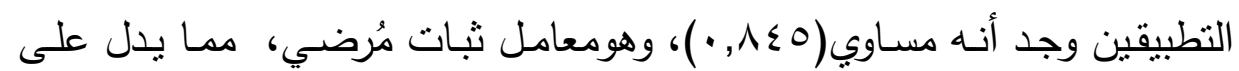
ثبات المقياس.

ب - مقياس اضطرابات الثخصية

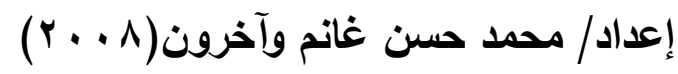
أ- وصف المقياس:

تكون المقياس في صورته النهائية دن • ب ا عبارة (10 مقياسا × 1 عبارات لكل مقياس) نم وضع (^) عبارات لكل اضطراب الثخصية بما يضمن- وزيادة - توافر عدد من المحكات الأساسية والتي إذا توافرت يتم النتخيص للاضط لاضطراب.

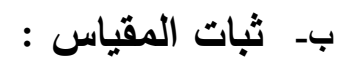
نم حساب الثبات في المقياس الاصلي بطريقة إعادة التطبيق بفاصل زمني قدره

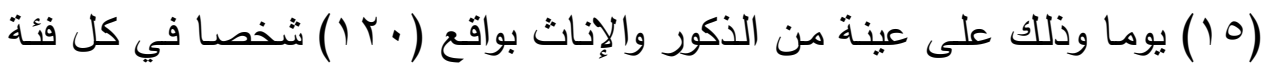

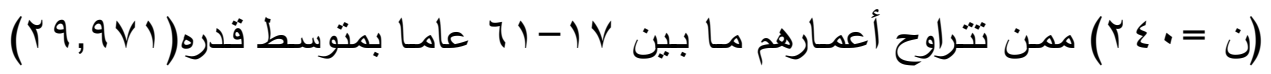
عامل وانحراف معياري قدره (r ع ع , ·) عاما لدى عينتي الذكور والإناث.

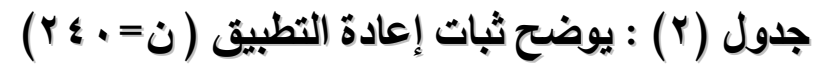

\begin{tabular}{|c|c|c|c|}
\hline الكلية (ذكور +إناتاث) & 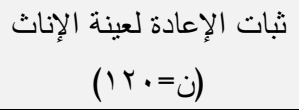 & الذبات الإعادة لعينة & المقاييس \\
\hline$\cdot, 9 \leq$ & $\cdot, \mathrm{VT}$ & $\cdot,(\mathrm{VI}$ & الثخصية البارانويدية \\
\hline •,9r & $\cdot, 7 \varepsilon$ & $\cdot$, , & الشخصية الفصامية النوع \\
\hline$\cdot, \wedge$ & $\cdot$, , 0 & •, 94 & الشخصية شبه الفصامية \\
\hline$\cdot, \wedge \varepsilon$ & $\cdot, \mathrm{VT}$ & $\cdot, 7 \varepsilon$ & الثخصبة المناهضة للمجتمع \\
\hline$\left.\cdot,{ }^{\prime}\right)$ & $\cdot, 74$ & $\cdot$, TV & الثخصية البينية \\
\hline$\cdot, \mathrm{VI}$ & $\cdot, 7 \leqslant$ & $\cdot, \wedge \varepsilon$ & الثخصية الهسنيرية \\
\hline$\cdot, \wedge$ & $\cdot, \mathrm{VT}$ & $\cdot, \vee_{0}$ & الثخصية النرجسية \\
\hline$\cdot$, Vo & $\cdot, \wedge \varepsilon$ & $\cdot, \mathrm{V} 4$ & الثخصية الوسواسية القهرية \\
\hline$\cdot, \mathrm{\vee} \wedge$ & $\cdot, \mathrm{V4}$ & $\cdot, \mathrm{VT}$ & الثخصية المتجنبة \\
\hline 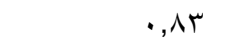 & $\cdot, \mathrm{V} V$ & $\cdot, V_{1}$ & الثخصية المعتمدة على غيرها \\
\hline
\end{tabular}

DOI: $10.12816 / 0051446$ 


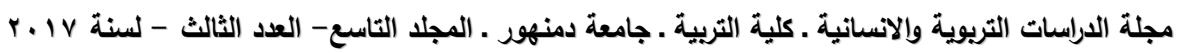

\begin{tabular}{|c|c|c|c|}
\hline الكلية (ذكور +إإناثة للعبنة & 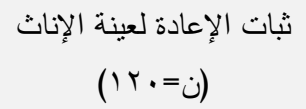 & الذبات الإعادة لعينة & المقاييس \\
\hline$\cdot, \wedge$ & $\cdot, \wedge \uparrow$ & $\cdot, \wedge 9$ & الشخصية العدوانية \\
\hline$\cdot, \wedge \vee$ & $\cdot, \mathrm{VT}$ & $\cdot, V V$ & الثخصية المكتئبة \\
\hline$\cdot, \mathrm{V} \cdot$ &., 90 & $\cdot, \mathrm{VT}$ & الثخصية الهازمة للذات \\
\hline$\cdot, 7 \mathrm{~V}$ & $\cdot, \wedge r$ & $\cdot, \wedge r$ & الثخصية السادية \\
\hline$\cdot, v_{1}$ & •, 94 & $\cdot, 77$ & الثخصية المازوخية \\
\hline
\end{tabular}

وتم حساب الثبات في الدراسة الحالية بطريقة إعادة التطبيق من خلال تطبيق المقياس مرتين بفارق زمني (0) يوما علي عينة قوامها ( (V) شخص تراوحت

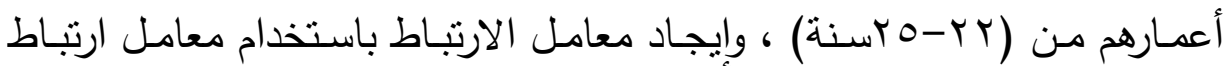
بيرسون بين التطبيقين وكانت النتائج كما هو موضتح في الجدول التالي: جدول (r) : يوضح معامالات الارتباط بين التطبيقين لمقياس اضطرابات الثخصية

\begin{tabular}{|c|c|c|c|}
\hline معاملات الثبات & اضطرابات الثخصية & الثبات & اضطرابات الثخصية \\
\hline 只, & الشخصية المتجنبة & $\cdot, \vee \vee \wedge$ & الثخصية البارانويدية \\
\hline$\cdot, \lambda{ }^{\prime}$ & على غيرها & $\cdot, \wedge r \leq$ & الثخصية الفصامية النوع \\
\hline$\cdot, \Lambda Y V$ & الثخصية العدوانية & $\cdot, \wedge \leqslant 0$ & الثخصية شبه الفصامية \\
\hline$\cdot, \wedge T \leq$ & الشخصية المكتنبة & $\cdot, \wedge \backslash 1$ & الثخصية المناهضة للمجتمع \\
\hline$\cdot, \vee \vee 90$ & للذات الشخصـــــة الهازمـــــة & $\cdot, \wedge Y K$ & الثخصية البينية \\
\hline$\cdot$, VTr & الثخصية السادية & $\cdot, \wedge \varepsilon r$ & الثخصية الهستيرية \\
\hline • & الثخصية المازوخية & $\cdot, \wedge 70$ & الثخصية النرجسية \\
\hline & & $\cdot, \lambda \Gamma$ & الثخصية الوسواسية القهرية \\
\hline
\end{tabular}

ويتضح من الجدول السابق أن جميع قيم معامالات الارتباط مرتفع ومقبولة، مما بدل علي تمتع المقياس بدرجة عالية من الثبات. . 


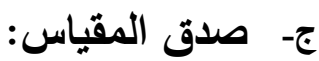

تم حساب الصدق في المقياس الأصلي بعدة طرق منها:

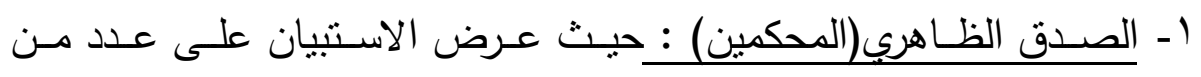

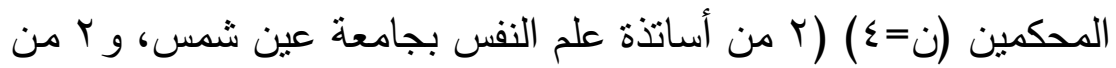

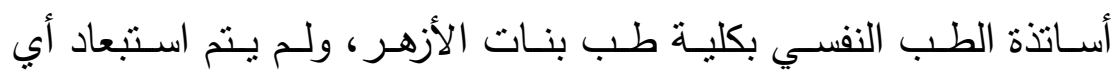

$$
\text { عبارات). }
$$

r- الاتسـاق الداخلي: حيث تم حساب معامل المقياس الفرعي والدرجة الكلية

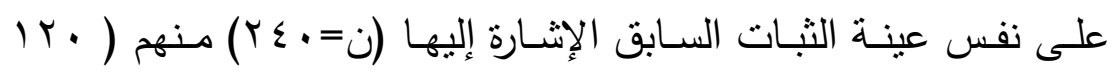

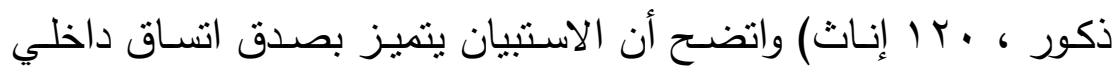

r- صدق المجموعات المتناقضة : حيث تم تطبيق الاستبيان على مجموعة

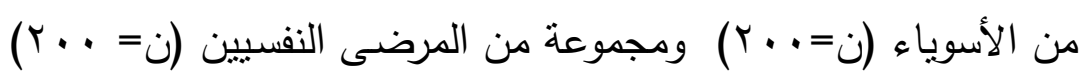

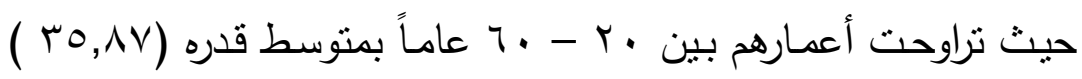

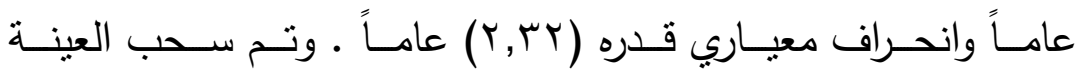

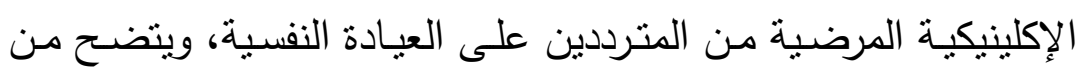
النتائج وجود فروق ذات دلالة إحصائية بين فئتي الأسوياء والمرضى فئي

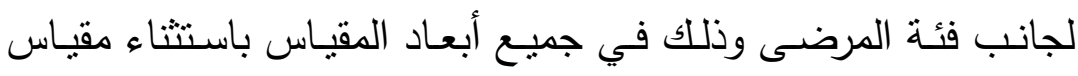
الثخصية البارانويدية مما يؤكد قدرة الاستبيان على التمييز بين الفئات المرضية والفئات غير المرضية أو الإكلنينكية.

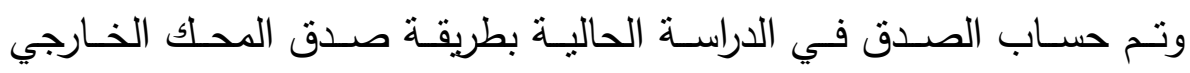

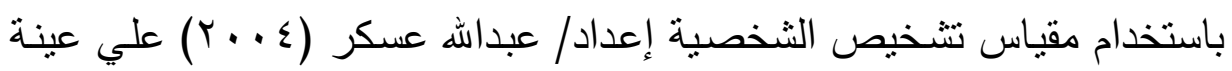

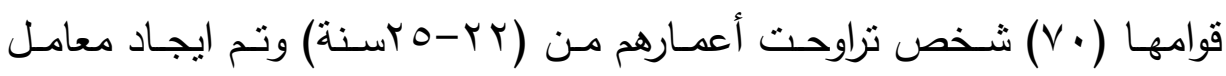

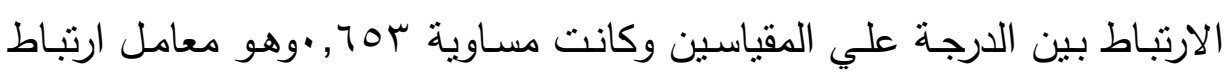

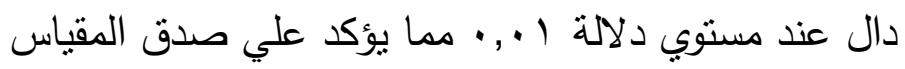




$$
\text { • فروض الفرض الأول: }
$$

ينص علي " يوجد ارتباط موجب دال إحصائياً بين درجات طلاب

الاراسـات العليا بكلية التربيـة علي مقياسي اضطرابات موجي دات الثخصية

\section{وعوامل ما وراء المعرفة"}

لاختبار صحة الفرض السابق استخدم "معامل ارتباط بيرسون "وكانت النتائج كما يلي :

جدول (1) معاملات الارتباط بين درجات طلاب الدراسات العليا بكلية التربية

\begin{tabular}{|c|c|c|c|c|c|c|}
\hline 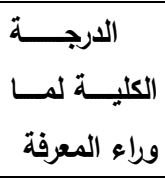 & 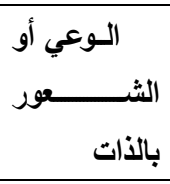 & لضبط الأفكار & المعرفية & السلبية المعتقدات & 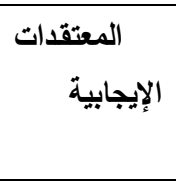 & الشخصية \\
\hline$(* *) \cdot,|r|$ & $(* *) \cdot,|r|$ & $(* *) \cdot, 111$ & $\cdot, \ldots \varepsilon$ & $(* *) \cdot, \wedge$. & $(*) \cdot, .0 r$ & البارانويدية \\
\hline$(* *) \cdot, Y \backslash 1$ & $(* *) \cdot, \cdot \vee r$ & $(* *) \cdot, 171$ & $(* *) \cdot, \cdot \wedge \wedge$ & $(* *) \cdot, 1 \circ V$ & $(* *) \cdot, 11 \mu$ & الفصامية النوعي \\
\hline$(* *) \cdot, I \vee r$ & $(* *) \cdot,|r|$ & $(* *) \cdot, \wedge \vee$ & $(* *) \cdot, r r_{1}$ & $(* *) \cdot, 1 \wedge$ &.,$\cdot r \leq$ & شبة الفصامية \\
\hline$(* *) \cdot, 17 V$ & $(* *) \cdot, 1$ rq & $(* *) \cdot, 1 \Gamma y$ & $(* *) \cdot, r \leq r$ & $(* *) \cdot, 190$ & $\cdot, \cdot 19$ & المضادة للمجتمع \\
\hline$(* *) \cdot, r r q$ & $(* *) \cdot, .91$ & $(* *) \cdot, r i r$ & $(* *) \cdot, r \wedge$ & $(* *),, \varepsilon \mid r$ & $\cdot, \cdot \leq 9$ & البينية \\
\hline$(* *) \cdot r \circ r$ & $(*) \cdot, \cdot 7 r$ & $(* *)$, ro. & $(* *) \cdot, \backslash \vee \wedge$ & $(* *) \cdot, r \circ \varepsilon$ & $(* *) \cdot, \cdot \wedge \wedge$ & الهستيرية \\
\hline$(* *) \cdot, r \cdot \Lambda$ & $\cdot, \cdot r \Lambda$ & $(* *) \cdot, 199$ & $\cdot, \cdot \leq \wedge$ & $(* *) \cdot, r \cdot v$ & $(* *) \cdot, \cdot \wedge \wedge$ & الترجسية \\
\hline$(* *) \cdot, 119$ & $(* *) \cdot, 1 \cdot r$ & $(* *) \cdot, \cdot \Lambda$ & $\cdot,+1 \leq$ & $\left({ }^{* *}\right) \cdot, \cdot \wedge 7$ & $\left({ }^{* *}\right) \cdot, \cdot \vee 7$ & 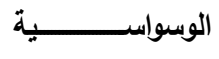 \\
\hline & & & & & & \\
\hline$(* *) \cdot, r r q$ & $\cdot, \cdot 1$ & $(* *) \cdot$, หฯ & $(* *) \cdot, r \leq 1$ & $(* *) \cdot, r r \varepsilon$ & $(* *) \cdot, \cdot 9 \leq$ & التجنبية \\
\hline$(* *) \cdot, r q \wedge$ & $(* *) \cdot, 117$ & $(* *) \cdot r \cdot r$ & $(* *) \cdot$, หร & $(* *) \cdot, r \cdot o$ & $(* *) \cdot, \cdot \vee \wedge$ & المعتمــــة علـــى \\
\hline & & & & & & غيرها \\
\hline$(* *) \cdot, 1 \wedge$ & $\cdot, \cdot \leq 9$ & $(* *) \cdot, 1 \leq$ & $(* *) \cdot, 1 \leq V$ & $(* *) \cdot, 199$ & $(* *) \cdot, .9 \varepsilon$ & السلبية العدوانية \\
\hline$(* *) \cdot, \varepsilon \cdot r$ & $(* *) \cdot, .9 \leq$ & $(* *) \cdot, r \bullet \wedge$ & $(* *) \cdot, r l$ & $(* *) \cdot, \varepsilon \vee ५$ & $(*) \cdot, \cdot 70$ & المكتئبة \\
\hline$(* *) \cdot$, r & $\cdot, \cdots r$ & $(* *) \cdot, r \mid V$ & $(* *) \cdot, r r o$ & $(* *) \cdot, r \leq \neg$ & $(* *) \cdot, I r \leq$ & الهازمة للذات \\
\hline$(*) \cdot, \cdot 7$. & $(*) \cdot, .07$ & ., t. & $(*) \cdot, \cdot 7 r$ & $\cdot, \cdot \leq \wedge$ & $(* *) \cdot, \cdot \vee v$ & السادية \\
\hline$\cdot, \cdot, \leqslant \Lambda$ & $(*) \cdot, .77$ & $(*) \cdot, .07$ & $(* *) \cdot, \cdot v_{1}$ & $(* *) \cdot, 110$ & $\cdot, \cdot \leq \wedge$. & المازوخية \\
\hline
\end{tabular}
علي مقياسي اضطرابات الشخصية وعوامل ما وراء المعرفة (ن = VYq) 


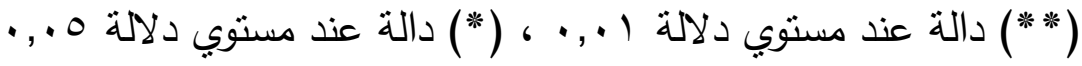

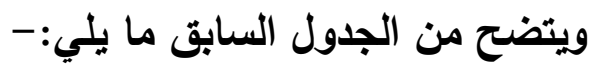

أولا: بالنسبة لعامل المعتقات الايجابية نحو الهم:-

جاءت النتائج لتؤكد علي وجود علاقة ارتباطية ذات دلالة إحصائية موجبة بين عامل المعتقدات الإيجابية نحو الهم وكل مـن اضطراب الثخصية (البارانويديـة، الفصامية النوعي، الهستيرية، النرجسية، الوسواسية القهرية، التجنبية، المعتمدة علي الإسية

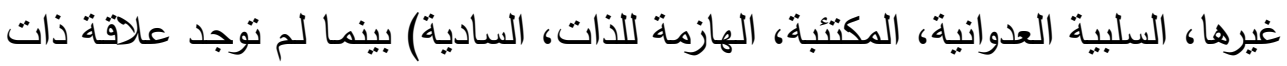
دلالــة إحصـائية بـين هذا العامـل وكل مـن اضـطراب الثخصية (ثـبه الفصـامية،

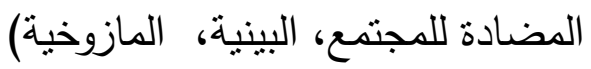
ثانياً: بالنسبة لعامل المعتقات السلبية نحو الأفكار المرتبطة بالعجز عن التحكم وإدراك الخطر :جاءت النتائج لتؤكد علي وجود علاقة ارتباطية ذات دلالة إحصائية موجبة بين

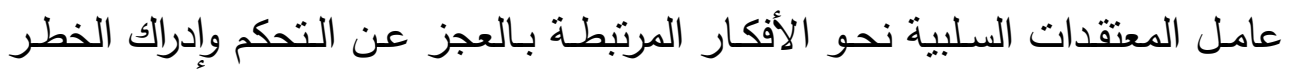
وكـل مـن اضـطراب الثخصـية (البارانويديـة، الفصـامية النـوعي، شـبه الفصـامية،

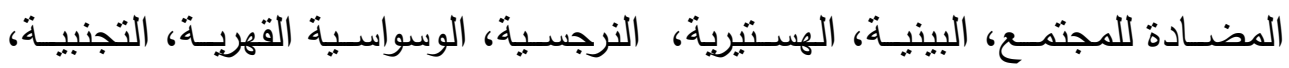

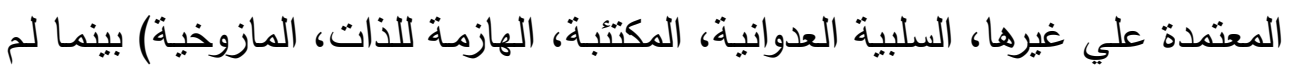
توجد علاقـة ذات دلالـة إحصـائية بين هذا العامل وكل مـن اضطراب الثخصية

(السادينة)

ثالثاً: بالنسبة لعامل الثقة المعرفية:-

جاءت النتائج لتؤكد علي وجود علاقة ارتباطية ذات دلالة إحصائية موجبة بين

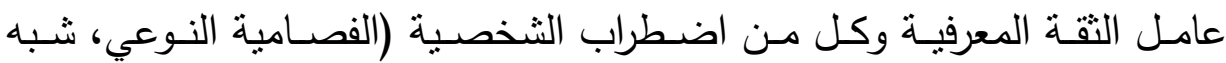
الفصامية، المضادة للمتمع، البينية، الهستيرية، التجنبية، المعتمدة علي غيرها،

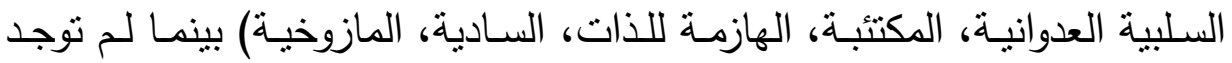


علاقـة ذات دلالــة إحصـائية بـين هـذا العامـل وكل مـن اضـطراب الثخصـية (البارانويدية، النرجسية، الوسواسية القهرية)

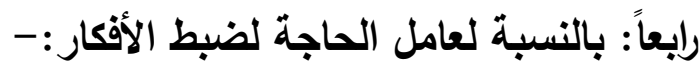
جاءت النتائج لتؤكد علي وجود علاقة ارتباطية ذات دلالة إحصائية موجبة بين عامل الحاجة لضبط الأفكار وكل من اضطراب الثخصية (البارانويدية، الفصامية

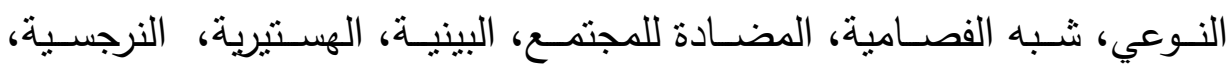
الوسواسية القهريـة، التجنبيـة، المعتمدة علي غيرهـا، السلبية العدوانيـة، المكتئبة،

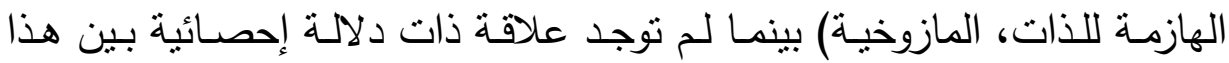
العامل وكل من اضطراب الثخصية ( السادية) خامساً: بالنسبة لعامل الوعي أو الثعور بالذات:-

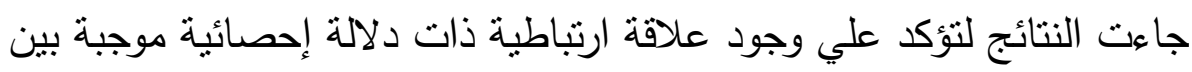

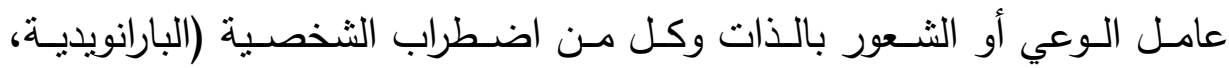

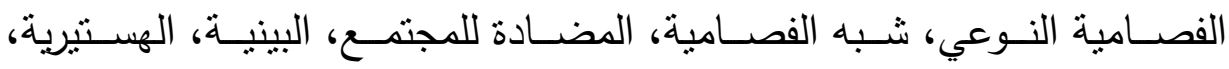
الوسواسية القهرية، المعتمدة علي غيرها، المكتبَة، السادية، المازوخيـة) بينما لم توجد علاقة ذات دلالة إحصائية بين هذا العامل وكل من اضطراب الثخصية (النرجسية، التجنبية، السلبية العدوانية، الهازمة للذات)

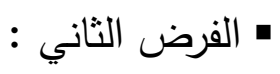
ينص علي " لا توجد فروق ذات دلالــة إحصـائية بين متوسـات درجـات

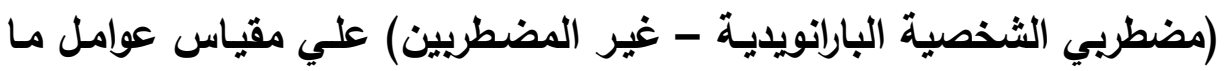
وراء المعرفة"

لاختبار صحة الفرض السابق استخدم اختبار "ت" للالاية الفروق بين المجموعات المستقلة ، وكانت النتائج كما يلي : 
عوامل ما وراء المعرفة ودورها في اضطرابات الثخصية د. قطب عبده خليل حنور د. محمود مغازي العطار

جدول (Y): قيمة "ت" ودلالتها الإحصائية بين بين متوسطات درجات (مضطريي

الشخصية البارانويدية - غير المضطربين) علي مقياس عوامل ما وراء المعرفة

\begin{tabular}{|c|c|c|c|c|c|}
\hline مستوى الدلالة & قيمة " ت" & الانحراف & المتوسط & اضطراب الشخصية & عوامل ما وراء المعرفة \\
\hline \multirow{2}{*}{ 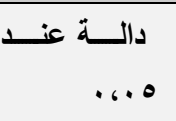 } & \multirow{2}{*}{ rrr, } & $\varepsilon, \leqslant 9$ & 17,19 & V. = vضطرب ن & \multirow{2}{*}{ نحو المعتقـــات الإيجابيـــة } \\
\hline & & $\varepsilon, \varepsilon r$ & $1 \leq, \leq r$ & غير مضطرب ن= v & \\
\hline \multirow[b]{2}{*}{ غير دالة } & \multirow[b]{2}{*}{$\cdot, \leqslant 00$} & $0,9 r$ & 17,94 & مضطرب ن= v V & \multirow{2}{*}{ 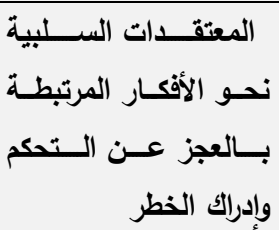 } \\
\hline & & 0,90 & $17, \leqslant V$ & 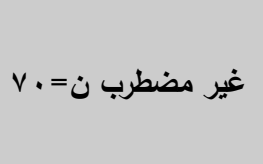 & \\
\hline \multirow{2}{*}{ غير دالة } & \multirow{2}{*}{$\cdot, r v i$} & $0, r_{0}$ & $1 \leq, \wedge 9$ & مضطرب ن= v v & \multirow{2}{*}{ الثقة المعرفية } \\
\hline & & $\varepsilon, r V$ & $1 \leqslant, 09$ & غير مضطرب ن= v & \\
\hline \multirow{2}{*}{ 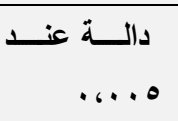 } & \multirow{2}{*}{$r, \cdot \varepsilon q$} & $\varepsilon, 79$ & $1 \wedge, 1 V$ & مضطرب ن= v v & \multirow{2}{*}{ الحاجة لضبط الأككار } \\
\hline & & $\varepsilon, V \varepsilon$ & $10, v \varepsilon$ & غير مضطرب ن= v & \\
\hline \multirow{2}{*}{ 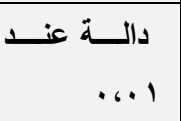 } & \multirow{2}{*}{ r, $\odot \vee ०$} & $0, r q$ & ry, rq & مضطرب ن= v v & \multirow{2}{*}{ 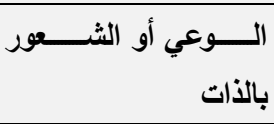 } \\
\hline & & $\varepsilon, 01$ & $r \cdot, o r$ & غير مضطرب ن= v & \\
\hline \multirow{2}{*}{ 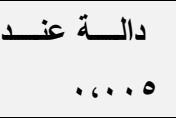 } & \multirow{2}{*}{$r, q \cdot v$} & $1 \mathrm{T,qV}$ & $\wedge \wedge, \wedge \uparrow$ & V. = مضطرب ن & \multirow{2}{*}{ الارجة الكلية } \\
\hline & & $1 \leq, 91$ & $\wedge 1, V^{4}$ & غير مضطرب ن= v & \\
\hline
\end{tabular}

\section{يتضح من الجدول السابق ما يلي:}

وجود فروق ذات دلالـة إحصـائية بين درجات(مضطربي الثخصية البارانويديـة -

غير المضـطربين) علي عوامـل مـا وراء المعرفـة (المعتقدات الايجابيـة نحو الهــالحاجة لضبط الأفكار - الوعي أو الثعور بالذات -الدرجة الكلية) لجانب مضطربي

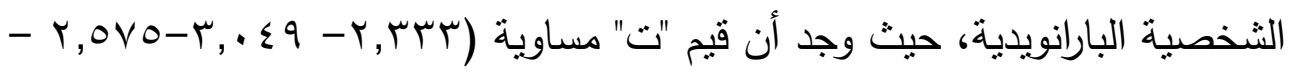
(r, , • V علي التوالي، وبالكثف عن دلالتهم الإحصائية وجد أنهم دالة عند مستوى دلالـة (0. . . -0 . ., • - •., •)، في حين لـم يوجد فـروق في عوامل(المعتقدات

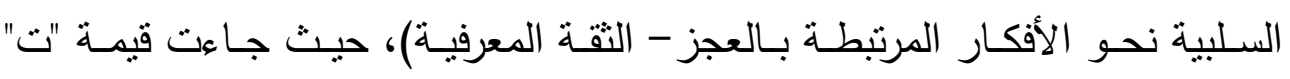

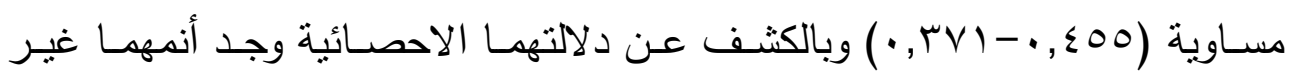
دالتان، مما بؤكد عدم تحقق الفرض الصفري. 


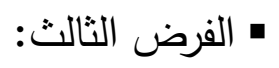

ينص علي " لا توجد فـروق ذات دلالــة إحصـائية بـين متوسطات درجـات (مضطربي الثخصية الفصـامية النـوعي - غير المضطربين) علـي مقيساس

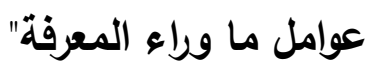

لاختبار صحة الفرض السابق استخدم اختبار "ت" لدلالة الفروق بين

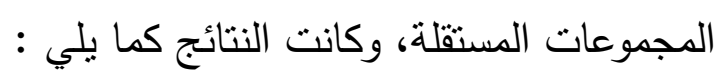

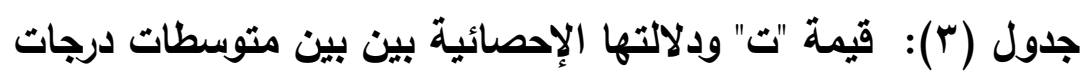

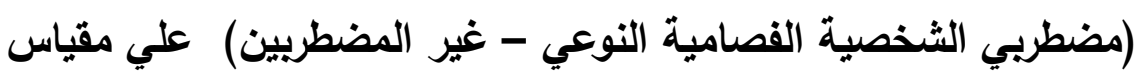

\begin{tabular}{|c|c|c|c|c|c|}
\hline مستوى الالالة & قيمة " ت" & 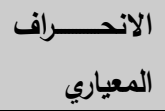 & المتوسط & 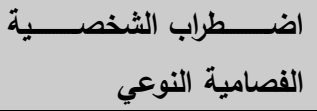 & المعرفة عوامـل مـــاء وراء \\
\hline \multirow{2}{*}{ غير دالة } & \multirow{2}{*}{$\cdot$, Ary } & $7, \cdot r$ & $10, \ldots$ & مضطرب ن= § & \multirow{2}{*}{ المعتقـــات الإيجابيـة } \\
\hline & & $\varepsilon, Y V$ & $14,9 \leq$ & غير مضطرب ن= ع r & \\
\hline \multirow[b]{2}{*}{ دالة عند ا . ... . } & \multirow[b]{2}{*}{$\bullet, \wedge \wedge \wedge$} & $\varepsilon, 0$ & $19, \leqslant 1$ & مضطرب ن= ؟ & \multirow{2}{*}{ 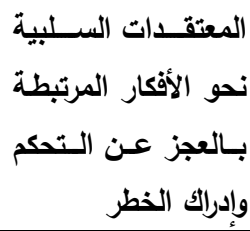 } \\
\hline & & $\leq, 7 \leq$ & $\mid r, \wedge \wedge$ & غير مضطرب ن=\& & \\
\hline \multirow{2}{*}{ دالة عند I ...، . } & \multirow{2}{*}{$\varepsilon, \cdot \leq V$} & $\varepsilon, 74$ & $1 \wedge, \vee 9$ & مضطرب ن= ع r & \multirow{2}{*}{ الثقة المعرفية } \\
\hline & & 0,rr & $\mid r, \wedge \Lambda$ & غير مضطرب ن=ء & \\
\hline \multirow{2}{*}{ دالة عند 1 . .، . } & \multirow{2}{*}{$0, v \leq 7$} & ט & $r \cdot, r T$ & مضطرب ن= § & \multirow{2}{*}{ الحاجة لضبط الأفكار } \\
\hline & & $\varepsilon, \cdot 9$ & 14,70 & غير مضطرب ن=ء & \\
\hline \multirow{2}{*}{ غير دالة } & \multirow{2}{*}{$1, r 79$} & $\varepsilon, r_{0}$ & 19,91 & مضطرب ن= ع & \multirow{2}{*}{ 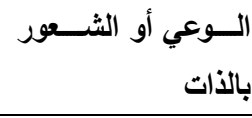 } \\
\hline & & $7,1$. & ri,or & غير مضطرب ن=\& & \\
\hline \multirow{2}{*}{ دالة عند I ..، . } & \multirow{2}{*}{$\varepsilon, 99$. } & r & $q r, r v$ & مضطرب ن= ع & \multirow{2}{*}{ الارجة الكلية } \\
\hline & & 10,01 & $\vee \bullet, \wedge \wedge$ & غير مضطرب ن= \& & \\
\hline
\end{tabular}

عوامل ما وراء المعرفة

يتضح من الجدول السابق ما يلي:

وجـود فـروق ذات دلالــة إحصـائية بـين درجات (مضـطربي الثخصـية الفصـامية

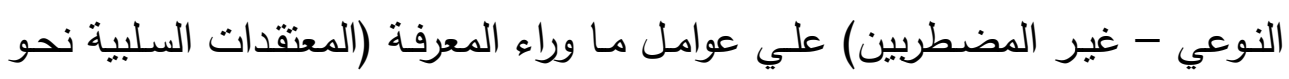


الأفكار المرتبطة بالعجز -التقة المعرفية - الحاجة لضبط الأفكار -الدرجة الكلية)

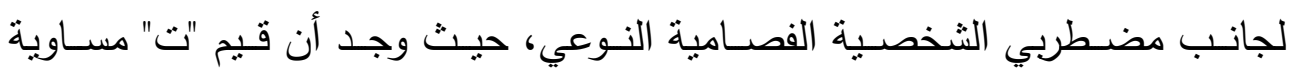

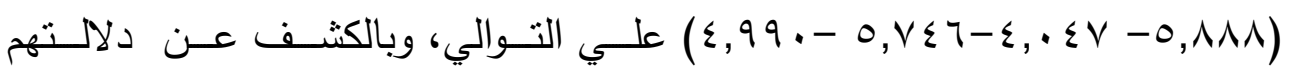

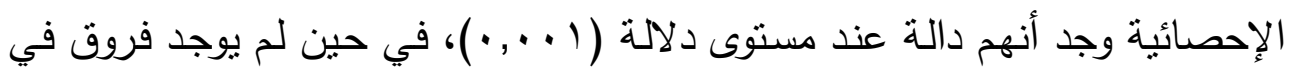

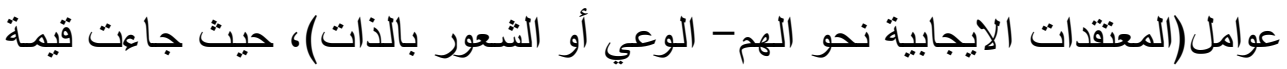

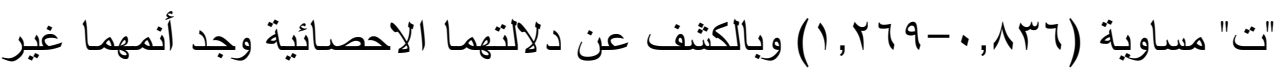
دالتان، مما يؤكد عدم تحقق الفرض الصفري.

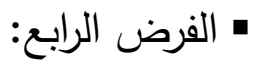
ينص علي " لا توجد فـروق ذات دلالــة إحصـائية بـين متوسـطات درجـات

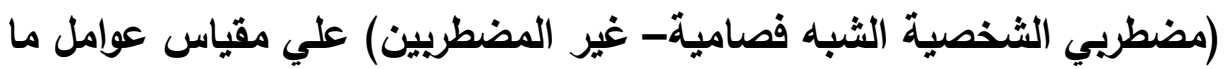

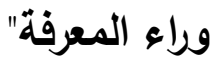

لاختبار صحة الفرض السابق استخدم اختبار "ت" لدلالة الفروق بين

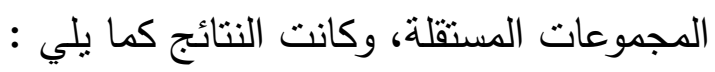

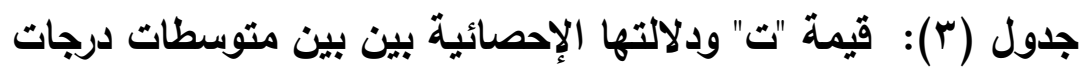
(مضطربي الشخصية الثبه فصامية - غير المضطربين) علي مقياس عوامل ما وراء المعرفة

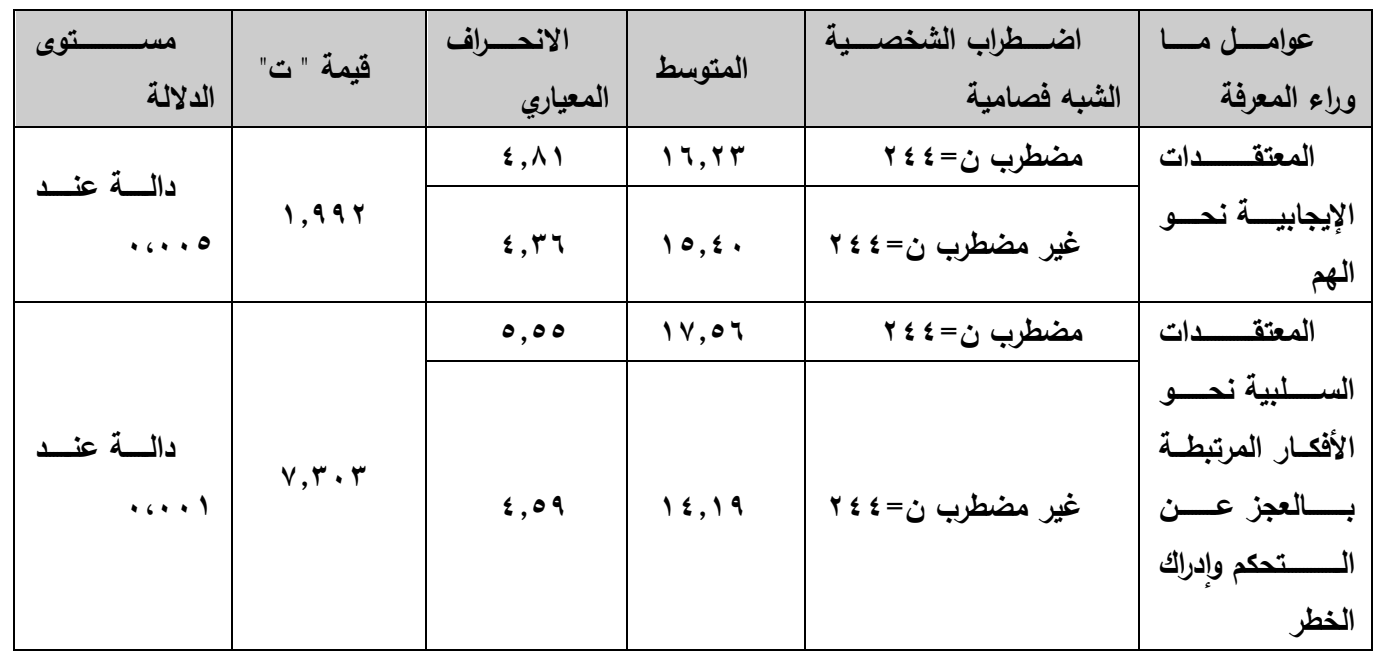




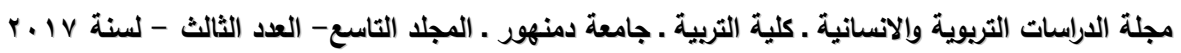

\begin{tabular}{|c|c|c|c|c|c|}
\hline \multirow{2}{*}{ ال... دالــة عـــــ } & \multirow{2}{*}{$7, V \cdot 7$} & $0, .1$ & $17, Y$. & مضطرب ن= § ؟ ب & \multirow{2}{*}{ الثقة المعرفية } \\
\hline & & $\varepsilon, Y r$ & $1 r, r q$ & غير مضطرب ن= ؟ ؟ r & \\
\hline \multirow{2}{*}{ 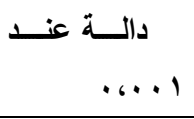 } & \multirow{2}{*}{$v, v 17$} & \&,r & $|\wedge, \leqslant|$ & مضطرب ن= ؟ ؟ r & \multirow{2}{*}{ 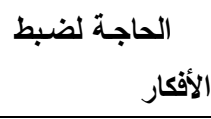 } \\
\hline & & $r, 7 q$ & $\mid 0,71$ & غير مضطرب ن= ؛ ؛ Y & \\
\hline \multirow{2}{*}{ 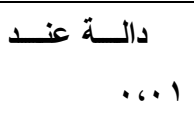 } & \multirow{2}{*}{$r, V \leq 0$} & 0,14 & $r \cdot, 00$ & مضطرب ن=؛ ؟ ب & \multirow{2}{*}{ الثعور بالذات الــــــوعي أو } \\
\hline & & $\{, \leqslant \wedge$ & Y I, Vo & غير مضطرب ن= ؟ ؟ Y & \\
\hline \multirow{2}{*}{ ال... دالــة عـــــ } & \multirow{2}{*}{ v, } & ir,vo & $\wedge \wedge, 90$ & مضطرب ن= \& § & \multirow{2}{*}{ الارجة الكلية } \\
\hline & & $M, \wedge r$ & $\Lambda \cdot, r \leq$ & غير مضطرب ن= ؛ ؛ Y & \\
\hline
\end{tabular}

يتضح من الجدول السابق ما يلي:

وجود فروق ذات دلالة إحصائية بين درجات(مضطربي الثخصية الثبه فصسامية

- غير المضطربين) علي عوامل ما وراء المعرفة (المعتقدات الايجابية نحو الهمالمعتقدات السلبية نحو الأفكار المرتبطة بـالعجز -التقة المعرفية - الحاجة لضبط الأفكار -الدرجة الكلية) لجانب مضطربي الثخصية الثبه فصامية، حيث وجد أن

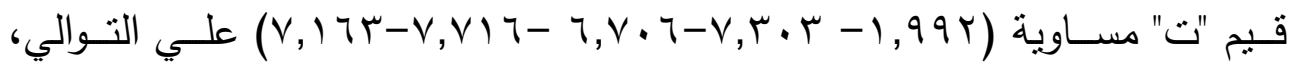
وبالكثف عن دلالتهم الإحصائية وجد أنهم دالة عند مستوى دلالة (من I ., . ( . , •) في حين جاءت الفروق دالة في جانب غير المضطربين في عامل (الوعي

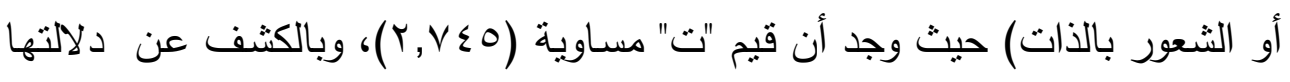
الإحصـائية وجد أنها دالـة عند مسـتوى دلالـة (مـن I +, ·)، ممـا يؤكد عدم تحقق الفرض الصفري.

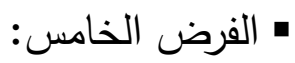
ينص علي " لا توجد فـروق ذات دلالـة إحصسائية بـين متوسـطات درجـات (مضـربي الشخصية المضـادة للمجتمـع - غيـر المضطربين) علي مقيـاس عوامل ما وراء المعرفة" لاختبار صحة الفرض السابق استخدم اختبار "ت" لدلالة الفروق بين المجموعات المستقلة، وكانت النتائج كما يلي : 
عوامل ما وراء المعرفة ودورها في اضطرابات الثخصية د. قطب عبده خليل حنور د. محمود مغازي العطار

جدول (ب) قيمة "ت" ودلالتها الإحصائية بين بين متوبطات درجات (مضطربي

الشخصية المضادة للمجتمع - غير المضطريين) علي مقياس عوامل ما وراء

المعرفة

\begin{tabular}{|c|c|c|c|c|c|}
\hline الدلالة مستوى & تيمة " & المعياري & المتوسط & المضادة للمجتمع الثخصية & عوامل ما وراء \\
\hline \multirow[b]{2}{*}{ غير دالة } & \multirow[b]{2}{*}{$1,1 \leq \varepsilon-$} & $\leq, \pi$ & $10, \wedge 4$ & مضطرب ن=r • 1 & \multirow{2}{*}{ المعتقدات الإيجابية } \\
\hline & & $\varepsilon, v$. & $10,1 r$ & غير مضطرب & \\
\hline \multirow[b]{2}{*}{ دالة عند } & \multirow[b]{2}{*}{$\varepsilon, .77$} & $0, r_{0}$ & $|v, r|$ & مضطرب ن=r r r 1. & \multirow{2}{*}{ بالعجز عن الأفكار المرتبطة التحكم وإدراك } \\
\hline & & $\varepsilon, 0$ & $1 \leq, O r$ & غير مضطرب & \\
\hline \multirow{2}{*}{ 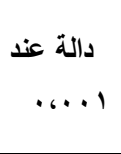 } & \multirow[b]{2}{*}{$7, Y 7 \leq$} & $0, r \varepsilon$ & $I \Lambda, r r$ & مضطرب ن=r = م & \multirow[b]{2}{*}{ الثقة المعرفية } \\
\hline & & $\leqslant, \leqslant 0$ & $1 \Psi, \Lambda \varepsilon$ & غير مضطرب & \\
\hline \multirow{2}{*}{ 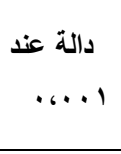 } & \multirow[b]{2}{*}{$r, q r r$} & $\varepsilon, V Y$ & $\curlywedge \wedge, \wedge \vee$ & مضطرب ن=r r r & \multirow[b]{2}{*}{ الحاجة لضبط الأفكار } \\
\hline & & $\leqslant, \leqslant 0$ & $17, r_{0}$ & غير مضطرب & \\
\hline \multirow{2}{*}{ دالة عند } & \multirow[b]{2}{*}{$\varepsilon, r, o$} & $\{, 07$ & $19,9 \leq$ & 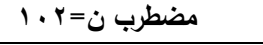 & \multirow{2}{*}{ بالذات أو الشعور } \\
\hline & & $r, q \leq$ & YY,01 & غير مضطرب & \\
\hline \multirow{2}{*}{ 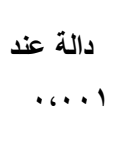 } & \multirow[b]{2}{*}{$\varepsilon, 19 r$} & $1 \leq, Y \wedge$ & $9 \cdot, r_{1}$ & مضطرب ن=r r • & \multirow[b]{2}{*}{ الارجة الكلية } \\
\hline & & Ir, $\leq \leq$ & $\Lambda Y, r_{0}$ & 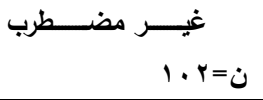 & \\
\hline
\end{tabular}

\section{يتضح من الجدول السابق ما يلي:}

وجـود فـروق ذات دلالــة إحصـائية بـين درجات (مضـطربي الثخصـية المضــادة

للمجتمع - غير المضطربين) علي عوامل ما وراء المعرفة (المعتقدات السلبية نحو الأفكار المرتبطة بالعجز -الثقة المعرفية - الحاجة لضبط الأفكار -الدرجة الكلية)

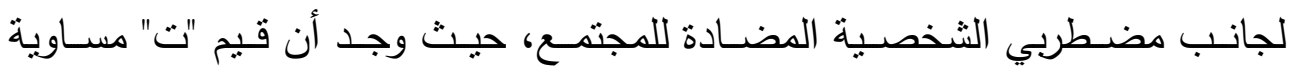

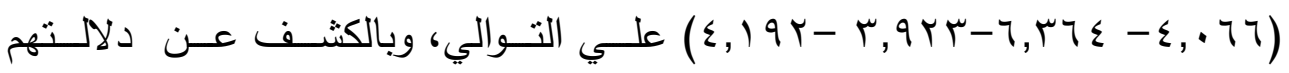
الإحصائية وجد أنهح دالة عند مستوى دلالة ( ( . ., )، ) في حين جاءت الفروق 
دالة في جانب غير المضطربين في عامل (الوعي أو الثعور بالذات) حيث وجد أن

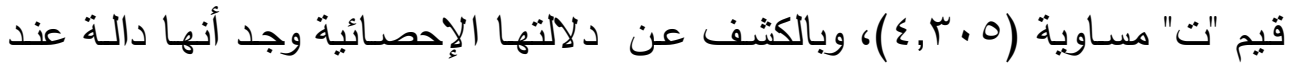

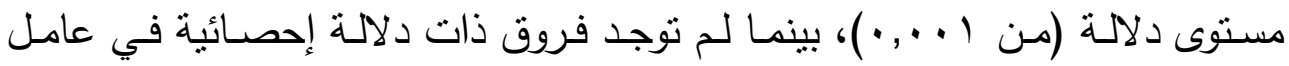

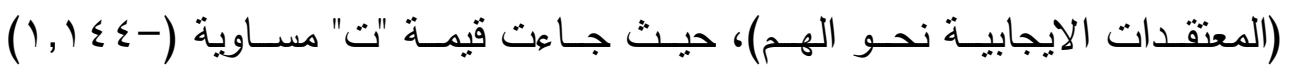
وبالكثف عن دلالتها الاحصائية وجد أنها غير دالة، مما يؤكد عدم تحقق الفرض الهـ الصفري.

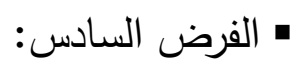

ينص علي " لا توجد فـروق ذات دلالـة إحصـائية بـين متوسـطات درجـات (مضطربي الثخصية البينية - غير المضطربين) علي مقياس عوامل ما وراء

لاختبـار صـحة الفرض السـابق اسـتخدم اختبـار "ت" لدلالـة الفروق بـين

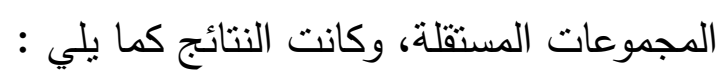

جدول (T) قيمة "ت" ودلالتها الإحصائية بين بين متوسطات درجات (مضطريي

\begin{tabular}{|c|c|c|c|c|c|}
\hline الدلاكة مســتوى & 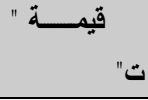 & المعياري & المتوسط & البينية اضـــــراب الثخصــــــة & عوامل ما وراء المعرفة \\
\hline \multirow{2}{*}{ غير دالة } & \multirow{2}{*}{$1, r \cdot T$} & $\varepsilon, 91$ & $17, \leqslant 0$ & مضطرب ن=7 11 & \multirow{2}{*}{ الهم } \\
\hline & & $\varepsilon, \wedge q$ & $10,7 \mathrm{~V}$ & غير مضطرب ن=7 11 & \\
\hline \multirow{2}{*}{ دالــــة عنـــــ } & \multirow[b]{2}{*}{$1 \leqslant, 9 \wedge 7$} & $\varepsilon, 7 r$ & $r \cdot, r)$ & مضطرب ن=8 117 & \multirow{2}{*}{ 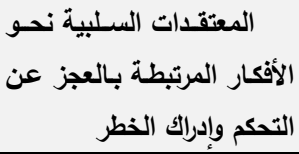 } \\
\hline & & $r, \uparrow \Lambda$ & Ir, $\{$. & غير مضطرب ن=8 11 & \\
\hline \multirow{2}{*}{ دالـــة عنــــ } & \multirow{2}{*}{$V, r q \leq$} & $\varepsilon, \vee \wedge$ & $17, V r$ & مضطرب ن=7 11 & \multirow{2}{*}{ الثقة المعرفية } \\
\hline & & $r, v q$ & Ir,० & غير مضطرب ن= | 1 = & \\
\hline \multirow{2}{*}{ 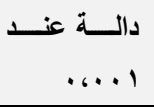 } & \multirow{2}{*}{$1 \cdot, 0 \wedge 7$} & $\varepsilon, 1 r$ & $r .10$ & مضطرب ن= 11 = & \multirow{2}{*}{ الحاجة لضبط الأفكار } \\
\hline & & $r, 7$ & $1 \leq, \sqrt{ } 4$ & غير مضطرب ن=11 11 & \\
\hline \multirow{2}{*}{ غير دالة } & \multirow{2}{*}{$1, \wedge \wedge r$} & $\varepsilon, 74$ & rr, IA & مضطرب ن=11 11 & \multirow{2}{*}{ الوعي أو الشعور بالذات } \\
\hline & & $\varepsilon, 71$ & rr, rr & غير مضطرب ن=| 11 & \\
\hline \multirow{2}{*}{ 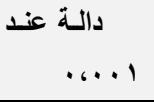 } & \multirow[b]{2}{*}{ 1., 1י } & 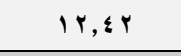 & $97,1$. & مضطرب ن=87 11 & \multirow{2}{*}{ الارجة الكلية } \\
\hline & & $11,9 r$ & $\vee \wedge, \vee \varepsilon$ & غير مضطرب ن=11 11 & \\
\hline
\end{tabular}

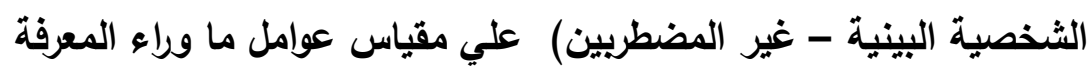


يتضح من الجدول السابق ما يلي:

وجود فروق ذات دلالة إحصائية بين درجات(مضطربي الثخصية البينية - غير المضطربين) علي عوامل ما وراء المعرفة (المعتقدات السلبية نحو الأفكار المرتبطة دهنة

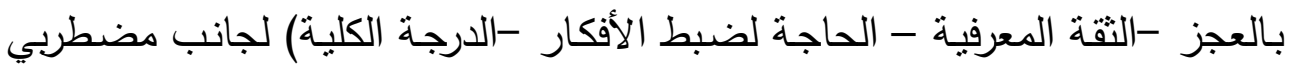

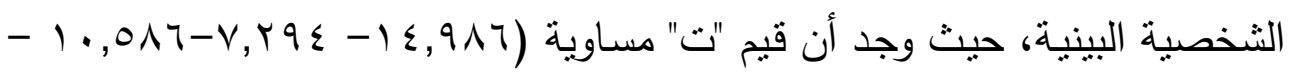
سדیر, • () علي التوالي، وبالكثـف عن دلالتهم الإحصـائية وجد أنهم دالـة عند مستوى دلالة ( ا . , •)، في حين لم يوجد فروق في عوامل(المعتقدات الايجابية نحو

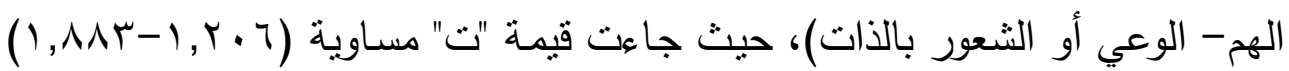

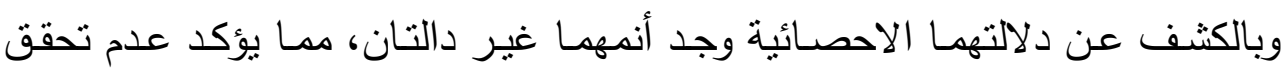
الفرض الصفري.

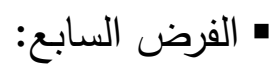
ينص علي " لا توجد فروق ذات دلالـة إحصـائية بـين متوسطات درجـات

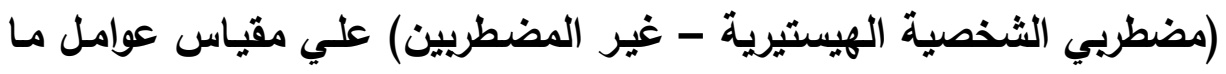

لاختبار صحة الفرض السابق استخدم اختبار "ت" لدلالة الفروق بين

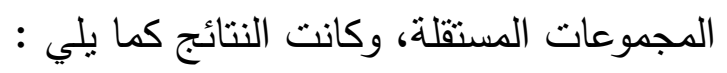

جدول (†) قيمـة "ت" ودلالتها الإحصائية بين بين متوسطات درجات (مضطربي

الثخصية الهيستيرية - غير المضطربين) علي مقياس عوامل ما وراء المعرفة

\begin{tabular}{|c|c|c|c|c|c|}
\hline 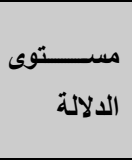 & قت قيمـــــة " & 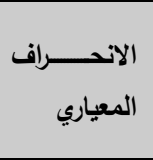 & المتوسط & 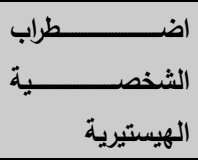 & عوامل ما وراء المعرفة \\
\hline \multirow[b]{2}{*}{ غير دالة } & \multirow[b]{2}{*}{$\cdot r \wedge r$} & $Y, \cdot Y$ & $10, r$. & مضطرب ن= = ؛ & \multirow{2}{*}{ الهمت المعتدات الإيجابــة نحـو } \\
\hline & & $\varepsilon, 9 \wedge$ & 10,4 & 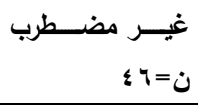 & \\
\hline \multirow{2}{*}{ دالــة عنـــ } & \multirow[b]{2}{*}{$\varepsilon, Y \wedge 0$} & $\varepsilon, \wedge 9$ & $19, .5$ & مضطرب ن= 7 ؛ & \multirow{2}{*}{ 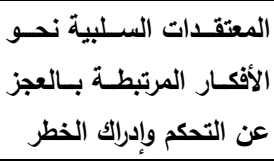 } \\
\hline & & $\bullet, \wedge r$ & $1 \leq, r \leqslant$ & 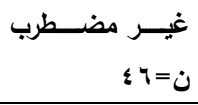 & \\
\hline دالـة عنــد & $r, 9 \leq \leq$ & $\varepsilon, 7$ & $11, Y 4$ & مضطرب ن= \ ؛ & الثقة المعرفية \\
\hline
\end{tabular}

DOI: $10.12816 / 0051446$ 


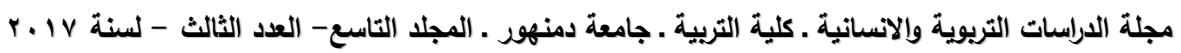

\begin{tabular}{|c|c|c|c|c|c|}
\hline$\cdots \cdot 1$ & & $0, \cdot 7$ & $1 \varepsilon, Y \wedge$ & 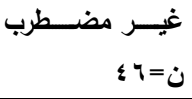 & \\
\hline \multirow{2}{*}{ 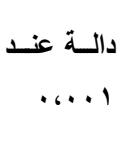 } & \multirow[b]{2}{*}{$r, r r r$} & $0, V Y$ & $19, Y 7$ & مضطرب ن= = ؛ & \multirow[b]{2}{*}{ الحاجة لضبط الأفكار } \\
\hline & & $\varepsilon, 0$. & $10, v$. & 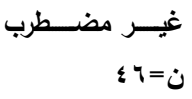 & \\
\hline \multirow{2}{*}{ 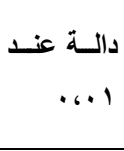 } & \multirow[b]{2}{*}{$\begin{array}{r}- \\
r, v \circ \leq\end{array}$} & $\varepsilon, \vee 0$ & $r \cdot, 1 r$ & مضطرب ن= \ ؛ & \multirow[b]{2}{*}{ الوعي أو الشعور بالذات } \\
\hline & & $r, \wedge r$ & $r Y, T I$ & 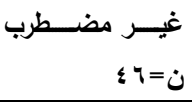 & \\
\hline \multirow{2}{*}{ 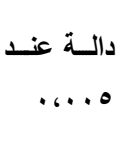 } & \multirow[b]{2}{*}{$r, \cdot r \wedge$} & $|r, \pi|$ & $q r, \ldots$ & مضطرب ن= ؟ ؛ & \multirow[b]{2}{*}{ الدرجة الكلية } \\
\hline & & $17, \leqslant 9$ & $\Lambda Y, \leqslant\rceil$ & 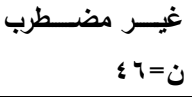 & \\
\hline
\end{tabular}

\section{يتضح من الجدول السابق ما يلي:}

وجود فروق ذات دلالـة إحصـائية بين درجات(مضطربي الشخصية الهيستيرية غير المضـطربين) علي عوامـل مـا وراء المعرفـة (المعتقدات السـلبية نحـو الأفكـار المرتبطة بـالعجز -الثقة المعرفيـة - الحاجة لضبط الأفكار -الدرجة الكلية) لجانب

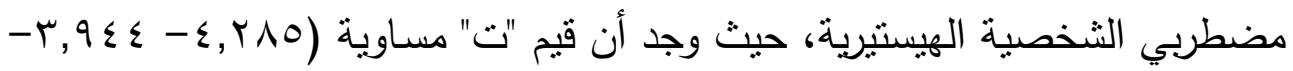

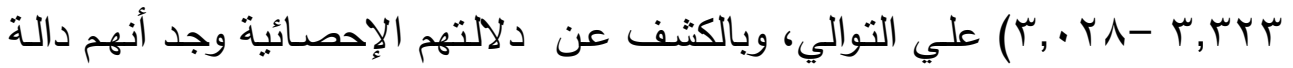
عند مسنتوى دلالة (من ( ., •-ه . . • )، ) في حين جاءت الفروق دالة في جانب غير المضطربين في عامل (الوعي أو الثعور بالذات) حيث وجد أن قيم "ت" مساوبة (Y, V0ะ-) I · • )، بينما لم توجد فروق ذات دلالة إحصائية في عامل (المعتقدات الايجابية نحو الهم)، حيـث جـاءت قيمـة "ت" مسـاوية (سمب, • ) وبالكثف عن دلالتها الاحصـائية وجد أنها غير دالة، مما يؤكد عدم تحقق الفرض الصفري.

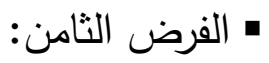
ينص علي " لا توجد فـروق ذات دلالـة إحصسائية بـين متوسـطات درجـات (مضطريجي الشخصية النرجسية - غير المضطربين) علي مقياس عوامل مـا 
لاختبار صحة الفرض السابق استخدم اختبار "ت" لدلالة الفروق بين

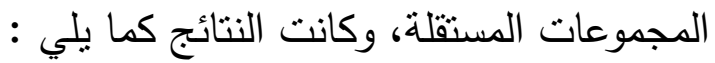

جدول (ץ) قيمة "ت" ودلالتها الإحصائية بين بين متوسطات درجات (مضطربي

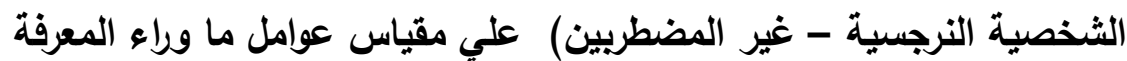

\begin{tabular}{|c|c|c|c|c|c|}
\hline مستوى الدلالة & قيمة " ت" & 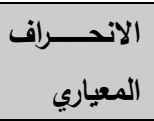 & المتوسط & النـــــــراب الثخصـــــية & عوامـل مـا وراء \\
\hline \multirow{2}{*}{ دالة عند } & \multirow{2}{*}{$\varepsilon, r \ldots$} & 0,19 & $1 V, \wedge q$ & مضطرب ن= ع V & \multirow{2}{*}{ الإيجابية نحو الهُق } \\
\hline & & $\varepsilon, .0$ & $1 \leq, 71$ & غير مضطرب ن= & \\
\hline \multirow[b]{2}{*}{ دالة عند } & \multirow[b]{2}{*}{$7, \leqslant \leqslant 0$} & $4, \cdot 1$ & $\mid v, r \wedge$ & مضطرب ن= ع & \multirow{2}{*}{ 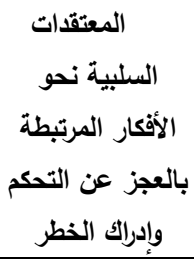 } \\
\hline & & $r, \wedge q$ & $11,9 V$ & غير مضطرب ن= ؛ V & \\
\hline \multirow{2}{*}{ 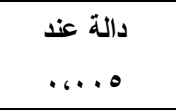 } & \multirow{2}{*}{ r,qrA } & 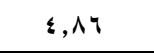 & $10, \mathrm{~V} \wedge$ & مضطرب ن= & \multirow{2}{*}{ الثقة المعرفية } \\
\hline & & $\varepsilon, r$. & Ir,OV & غير مضطرب ن= & \\
\hline \multirow{2}{*}{ دالة عند } & \multirow{2}{*}{$\vee, \vee v$. } & $\varepsilon, r q$ & 11,70 & مضطرب ن= ع V & \multirow{2}{*}{ الحاجة لضبط } \\
\hline & & r,rr & IT, & غير مضطرب ن= \& & \\
\hline \multirow{2}{*}{ غير دالة } & \multirow{2}{*}{$1, \cdot r^{4}$} & $\leq, 7 V$ & $r 1, \leqslant r$ & مضطرب ن= ع & \multirow{2}{*}{ الثعور بالأات أو } \\
\hline & & $\varepsilon, 9 \leqslant$ & $r \cdot, r r$ & غير مضطرب ن= \& & \\
\hline \multirow{2}{*}{ دالة عذ } & \multirow{2}{*}{$\wedge, \leqslant q \wedge$} & $|r, \pi|$ & $91,1 \leq$ & V Vضطرب ن= ع & \multirow{2}{*}{ الارجة الكلية } \\
\hline & & $9, \wedge 9$ & $V \varepsilon, 01$ & غير مضطرب ن= § V & \\
\hline
\end{tabular}

يتضح من الجدول السابق ما يلي:

وجود فروق ذات دلالـة إحصـائية بين درجات(مضطربي الثخصية النرجسية -

غير المضطربين) علي عوامل مـا وراء المعرفة (المعتقدات الايجابيـة نحو الهم المعتقدات السلبية نحو الأفكار المرتبطة بـالعجز -التقة المعرفية - الحاجـة لضبط

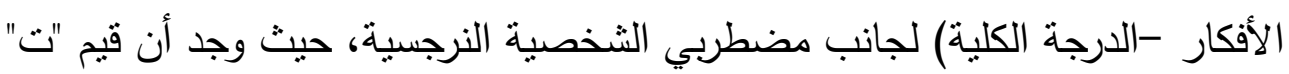

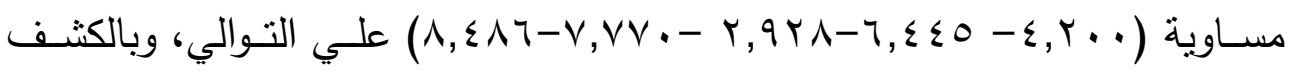
عن دلالتهم الإحصائية وجد أنهم دالة عند مستوى دلالة ( ( . , •-ه . ., •)، في حين لم يوجد فروق في (الوعي أو الثـعور بالذات)، حيث جاءت قيمة "ته" مساوية 
( T • , ا ) وبالكثف عن دلالتها الاحصائية وجد أنها غير دالة، مما يؤكد عدم تحقق الفرض الصفري.

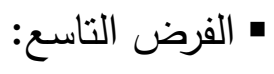

ينص علي " لا توجد فـروق ذات دلالـة إحصـائية بـين متوسـات درجـات

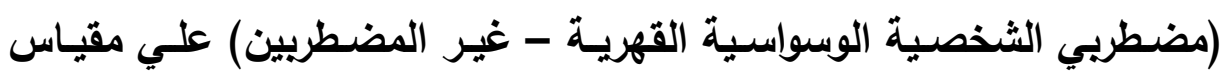

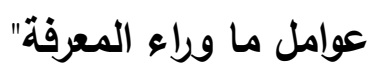

لاختبار صحة الفرض السابق استخدم اختبار "ت" للالاية الفروق بين

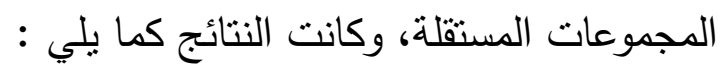

جدول (ץ) قيمة "ت" ودلالتها الإحصائية بين بين متوسطات درجات (مضطربي

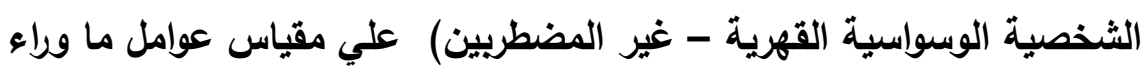

المعرفة

\begin{tabular}{|c|c|c|c|c|c|}
\hline الدلاكة مســــتوى & تقيــة " & 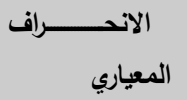 & المتوسط & 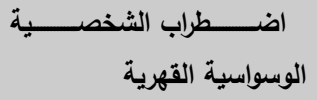 & المعرفة عوامـلـل مـــــــاء وراء \\
\hline \multirow{2}{*}{ 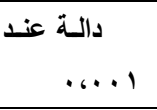 } & \multirow{2}{*}{$\varepsilon, T \vee 0$} & $\varepsilon, \uparrow \wedge$ & 18,17 & مضطرب ن= צ & \multirow{2}{*}{ الإليجابية نحو الهم } \\
\hline & & $\varepsilon, \wedge \vee$ & $10, Y r$ & غير مضطرب ن= = Y r & \\
\hline \multirow[b]{2}{*}{ 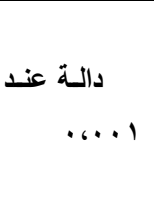 } & \multirow[b]{2}{*}{$r, v \cdot \varepsilon$} & $0, V H$ & 19,84 & مضطرب ن= צ & \multirow{2}{*}{ 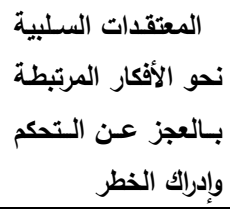 } \\
\hline & & $0, \leqslant 4$ & $1 \leqslant, 97$ & غير مضطرب ن=YY & \\
\hline \multirow{2}{*}{ غير دالة } & \multirow{2}{*}{$\cdot, \circ \vee V$} & $\varepsilon, \wedge 9$ & $1 \leqslant, 9 V$ & مضطرب ن=צr & \multirow{2}{*}{ الثقة المعرفية } \\
\hline & & $0, \cdot r$ & $1 \leqslant, V Y$ & غير مضطرب ن= Y Y & \\
\hline \multirow{2}{*}{ 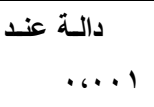 } & \multirow{2}{*}{$\varepsilon, 1 \vee \wedge$} & $\varepsilon, 1 r$ & $1 \wedge, 14$ & مضطرب ن=צ r r & \multirow{2}{*}{ الأفكار } \\
\hline & & $\{, 07$ & 17,00 & غير مضطرب ن= צ r r & \\
\hline \multirow{2}{*}{ 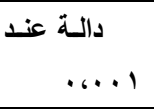 } & \multirow{2}{*}{$0, .17$} & $\varepsilon, \infty$ & Yr,O. & مضطرب ن=ף & \multirow{2}{*}{ 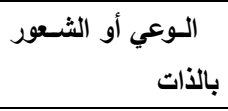 } \\
\hline & & $\varepsilon, 71$ & $r \cdot, \varepsilon q$ & غير مضطرب ن= צ Y & \\
\hline \multirow{2}{*}{ 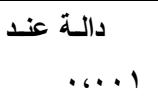 } & \multirow{2}{*}{$7, .99$} & $|r, v|$ & $\wedge 9,01$ & مضطرب ن= צ Y r & \multirow{2}{*}{ الارجة الكلية } \\
\hline & & $1 \leq, \wedge \Lambda$ & 11,90 & غير مضطرب ن= Y Y r & \\
\hline
\end{tabular}

يتضح من الجدول السابق ما يلي:

وجـود فـروق ذات دلالــة إحصـائية بـين درجات(مضـطربي الثخصـية الوسواسـية

القهرية - غير المضطربين) علي عوامل ما وراء المعرفة (المعتقدات الايجابية نحو دروبه 
الهم -المعتقدات السلبية نحو الأفكار المرتبطة بالعجز - الوعي أو الثعور بالذات-

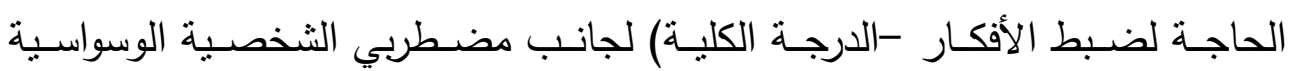

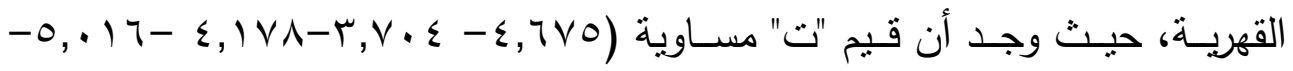

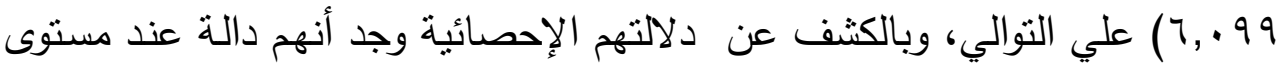

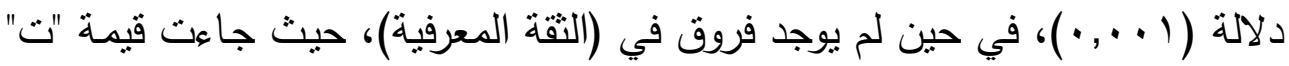
مساوية (OVV , • · ) وبالكثف عن دلالتها الاحصـائية وجد أنها غير دالة، مما يؤكد عدم تحقق الفرض الصفري.

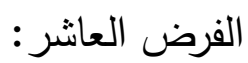

ينص علي " لا توجد فـروق ذات دلالــة إحصـائية بـين متوسـطات درجـات (مضطري الثخصية التجنبية - غير المضطريين) علي مقياس عوامل ما وراء

المعرفة" - مبطيب

لاختبار صحة الفرض السابق استخدم اختبار "ت" لدلالة الفروق بين

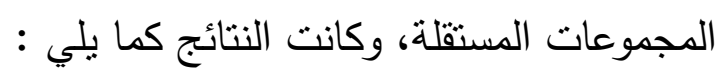

جدول (r) قيمة "ت" ودلالتها الإحصائية بين بين متوسطات درجات (مضطربي

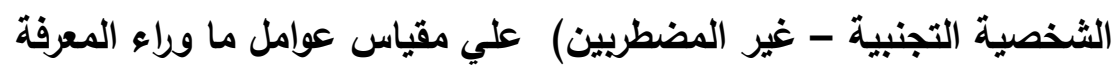

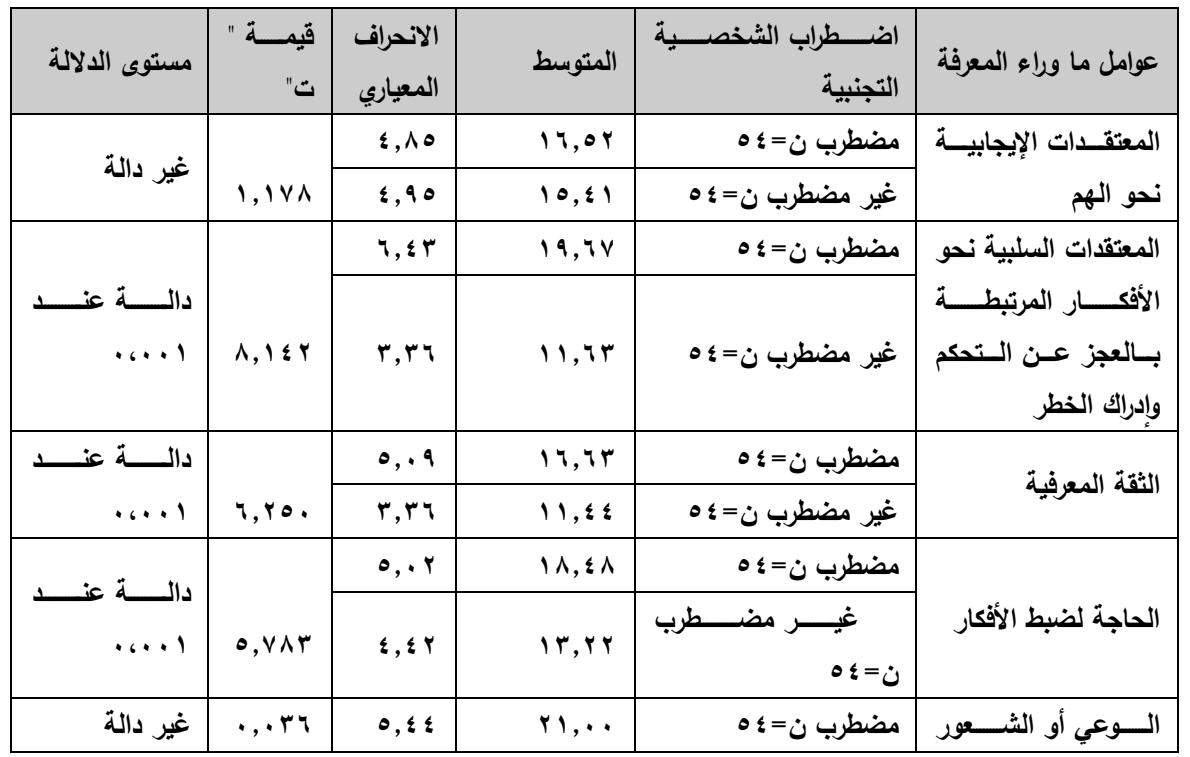

DOI: $10.12816 / 0051446$ 


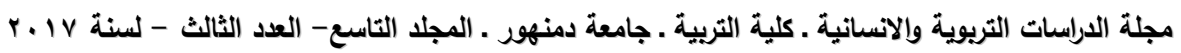

\begin{tabular}{|c|c|c|c|c|c|}
\hline & & $0, Y V$ & $r \cdot, 97$ & غير مضطرب ن=؛ ه & بالذات \\
\hline \multirow{2}{*}{ 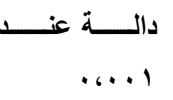 } & \multirow{2}{*}{ 7,974 } & 17,97 & $q r, r$. & مضطرب ن=؛ 0 & \multirow{2}{*}{ الارجة الكلية } \\
\hline & & $11, \wedge 9$ & VY,TV & غير مضطرب ن=؛ ه & \\
\hline
\end{tabular}

\section{يتضح من الجدول السابق ما يلي:}

وجود فروق ذات دلالة إحصائية بين درجات(مضطربي الثخصية التجنبية - غير

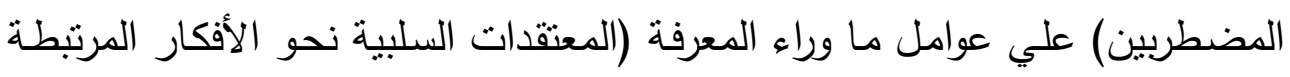

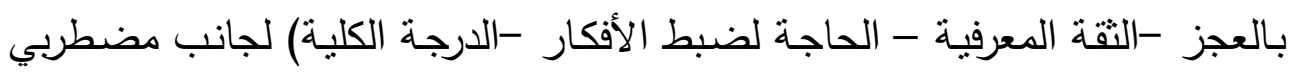

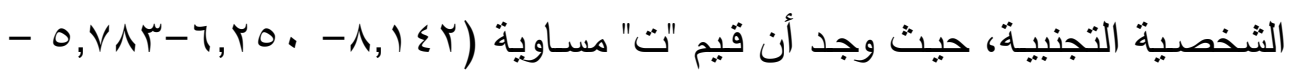

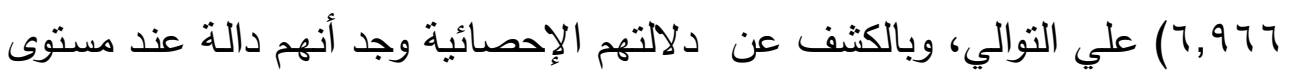
دلالة ( ( . , •)، في حين لم يوجد فروق في عوامل(المعتقدات الايجابية نحو الهم-

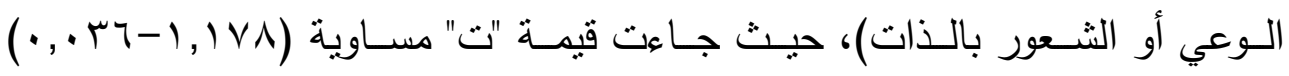

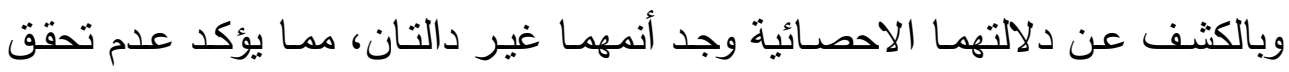
الفرض الصفري.

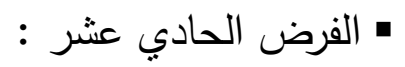

ينص علي " لا توجد فـروق ذات دلالـة إحصـائية بـين متوسـطات درجـات

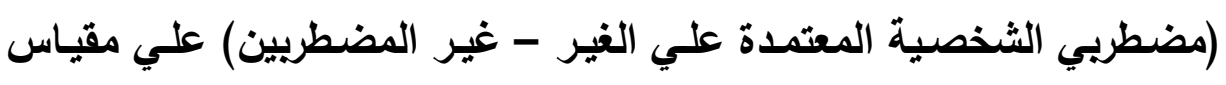

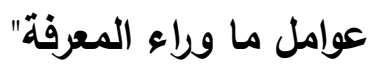

لاختبار صحة الفرض السابق استخدم اختبار "ت" للالاية الفروق بين

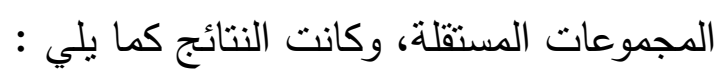

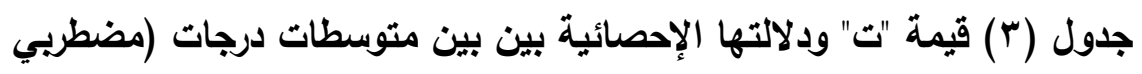
الثخصية المعتمدة علي الغير - غير المضطربين) علي مقياس عوامل ما وراء

\begin{tabular}{|c|c|c|c|c|c|}
\hline الدلالة مسـتوى & تقيمــة " & المعياري & المتوسط & 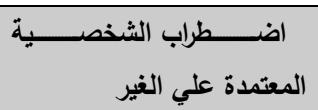 & 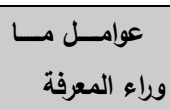 \\
\hline \multirow[b]{2}{*}{ غير دالة } & \multirow[b]{2}{*}{$1,1 \vee 9$} & $\varepsilon, \wedge \varepsilon$ & $10, \wedge \leqslant$ & مضطرب ن= & \multirow{2}{*}{ 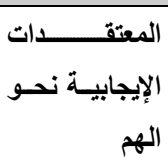 } \\
\hline & & $£, \wedge 7$ & $10, r$. & غير مضطرب ن= § Y Y & \\
\hline
\end{tabular}

$$
\text { المعرفة }
$$


عوامل ما وراء المعرفة ودورها في اضطرابات الثخصية د. قطب عبده خليل حنور د. دحمود مغازي العطار

\begin{tabular}{|c|c|c|c|c|c|}
\hline \multirow[b]{2}{*}{ 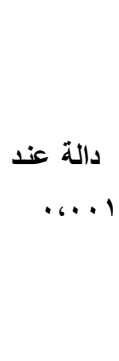 } & \multirow[b]{2}{*}{$1 ., 090$} & $0, \leqslant 4$ & $I A, Y V$ & مضطرب ن= = צr & \multirow[b]{2}{*}{ 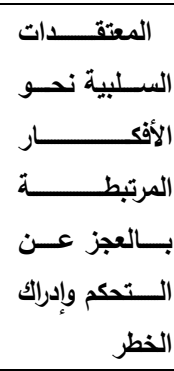 } \\
\hline & & $\varepsilon, Y q$ & Tr, & غير مضطرب ن= \& Y Y & \\
\hline \multirow{2}{*}{ 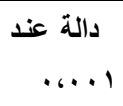 } & \multirow{2}{*}{$V, \leqslant r r$} & $\varepsilon, 91$ & $19, \leqslant 1$ & مضطرب ن= & \multirow{2}{*}{ لمعرفية الثق } \\
\hline & & $\varepsilon, r$. & $1 \%, 11$ & غير مضطرب ن= \& Y Y & \\
\hline \multirow{2}{*}{ ال... الة عند } & \multirow{2}{*}{$11,1 \times 4$} & $\{, \leqslant 4$ & $19, . r$ & مضطرب ن= § צr & \multirow{2}{*}{ لأفكار } \\
\hline & & r,OV & $1 \leqslant, v_{0}$ & غير مضطرب ن= \& Y Y & \\
\hline \multirow{2}{*}{ ه... . . . } & \multirow{2}{*}{$r, \leqslant 9 \wedge$} & צ, ז, & $r \cdot, \wedge \Lambda$ & مضطرب ن= & \multirow{2}{*}{ لثعبور بالذات الــــوعي أو } \\
\hline & & $\varepsilon, \varphi^{\prime}$ & $r 1, q r$ & غير مضطرب ن= \&Y Y & \\
\hline \multirow{2}{*}{ ال. ... } & \multirow{2}{*}{$9, \leq \leqslant 1$} & $1 \%, \leqslant 4$ & $9 \cdot, \leqslant 1$ & مضطرب ن= \& Y r & \multirow{2}{*}{ الدرجة الكلية } \\
\hline & & Ir,Yr & $\vee \wedge, 01$ & غير مضطرب ن= \& Y T & \\
\hline
\end{tabular}

\section{يتضح من الجدول السابق ما يلي:}

وجود فروق ذات دلالة إحصـائية بين درجات(مضطربي الثخصية المعتمدة علي

الغير - غير المضـطربين) علي عوامـل مـا وراء المعرفـة (المعتقدات السـلبية نحو الأفكار المرتبطة بـالعجز - الثقة المعرفيـة- الحاجـة لضبط الأفكار -الدرجـة الكلبـة) لجانب مضـطربي الثخصية المعتمدة علي الغير ، حيـث وجد أن قبم "ت" مسـاوية

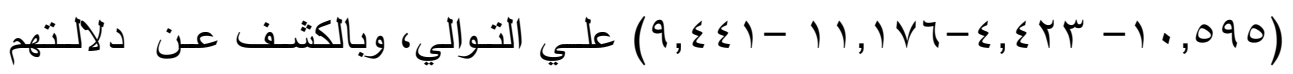
الإحصائية وجد أنهح دالة عند مستوى دلالة ( ( . ., )، ) في حين جاءت الفروق دالة في جانب غير المضطربين في عامل (الوعي أو الثُعور بالذات) حيث وجد أن

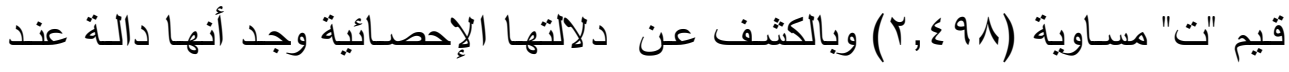
مسـتوى دلالـة (مـن 0 . , ·)، بينمـا لـم توجد فروق ذات دلالـة إحصـائية في عامـل (المعتقدات الايجابية نحو الهم)، حيث جاءت قيمة "ت" مساوية (1 V9 , l ) وبالكثف عن دلالتها الاحصائية وجد أنها غير دالة، مما يؤكد عدم تحقق الفرض الصفري.

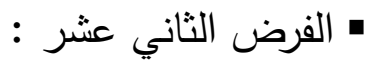


ينص علي " لا توجد فروق ذات دلالـة إحصـائية بـين متوسطات درجـات

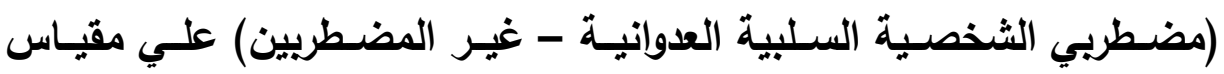

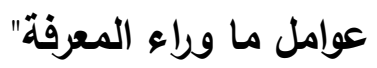
لاختبار صحة الفرض السابق استخدم اختبار "ت" للالاية الفروق بين

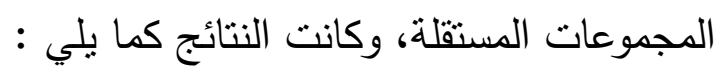

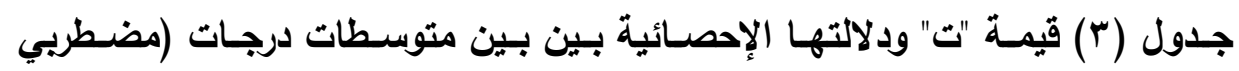

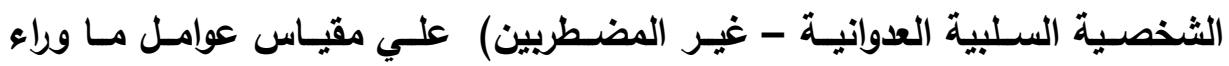

المعرفة

\begin{tabular}{|c|c|c|c|c|c|}
\hline 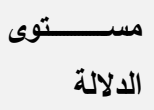 & قيمة " ت" & الانحــراف & المتوبط & السلبية العدوابية الشخصية & المعرفة عوامسل مــا وراء \\
\hline \multirow{2}{*}{ دالــــة عنــــ } & \multirow{2}{*}{ r, Y०. } & $\varepsilon, \varepsilon r$ & 18,10 & مضطرب ن=0 & \multirow{2}{*}{ نحو الهم المعتقات الإيجابية } \\
\hline & & r, & $10, Y \wedge$ & غير مضطرب ن=8 1 & \\
\hline \multirow[b]{2}{*}{ د. د. . . . . ــــة عنــــ } & \multirow[b]{2}{*}{$r, 919$} & $0, r_{0}$ & IV, Yo & مضطرب ن=0 & \multirow{2}{*}{ 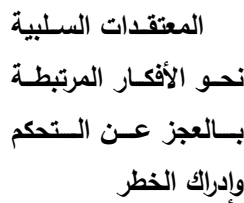 } \\
\hline & & $0, .9$ & $1 \varepsilon, 7$. & غير مضطرب ن=0 & \\
\hline \multirow{2}{*}{ دالـــة عنـــ } & \multirow{2}{*}{$r, \varepsilon \Lambda}$. & $0, M_{1}$ & $17, Y \wedge$ & مضطرب ن=0 & \multirow{2}{*}{ الثقة المعرفية } \\
\hline & & $\Gamma, \leqslant \wedge$ & $1 \leq, r Y$ & غير مضطرب ن=8 1 & \\
\hline \multirow{2}{*}{ غير دالة } & \multirow{2}{*}{$1,0 Y 1$} & $\varepsilon, 91$ & $1 \wedge, r \leq$ & مضطرب ن=0 & \multirow{2}{*}{ الأفكار } \\
\hline & & צו צ & $1 V, .7$ & غير مضطرب ن=ه ؟ & \\
\hline \multirow{2}{*}{ غير دالة } & \multirow{2}{*}{$1,07 \leqslant-$} & $\varepsilon, V Y$ & $r \cdot, V V$ & مضطرب ن=0 & \multirow{2}{*}{ بالذات الـوعي أو الثـعور } \\
\hline & & \&,9Y & $r r, . q$ & غير مضطرب ن=0 1 & \\
\hline \multirow{2}{*}{ 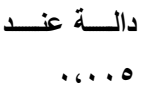 } & \multirow{2}{*}{$r, q \cdot V$} & Ir,v. & $\wedge ৭, \vee \wedge$ & مضطرب ن=0 & \multirow{2}{*}{ الارجة الكلية } \\
\hline & & Ir,Or & ט, & غير مضطرب ن=0 1 & \\
\hline
\end{tabular}

\section{يتضح من الجدول السابق ما يلي:}

وجود فروق ذات دلالة إحصائية بين درجات(مضطربي الثخصية السلبية العدوانية - غير المضطربين) علي عوامل ما وراء المعرفة (المعتقدات الايجابية نحو الهم المعتقدات السلبية نحو الأفكار المرتبطـة بـالعجز -التقـة المعرفيـة -الدرجـة الكليـة)

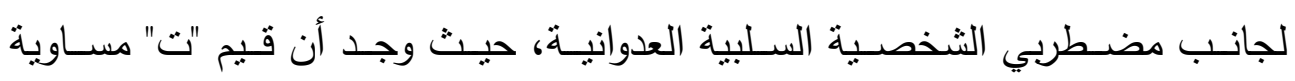


( ) علـي التـوالي، وبالكثـف عـن دلالـتنهم

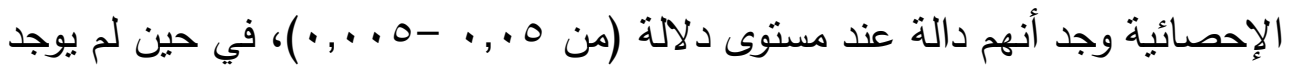

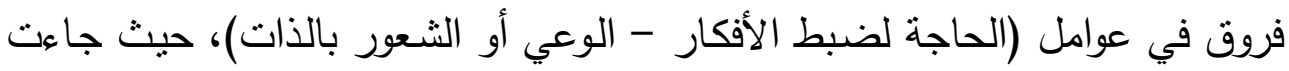

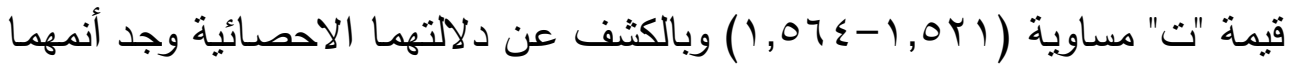
غير دالتان، مما يؤكد عدم تحقق الفرض الصفري.

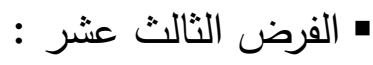

ينص علي " لا توجد فروق ذات دلالـة إحصـائية بـين متوسطات درجـات

(مضطريي الثخصية المكتئبة - غير المضطريين) علي مقياس عوامل ما وراء

المعرفة"

لاختبار صحة الفرض السابق استخدم اختبار "ت" لدلالة الفروق بين

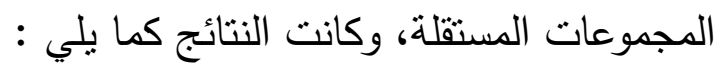

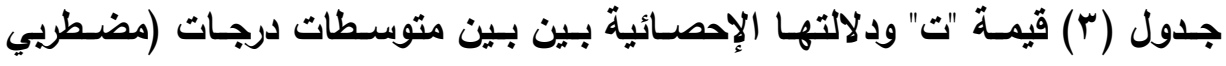

الشخصية المكتبة - غير المضطربين) علي مقياس عوامل ما وراء المعرفة

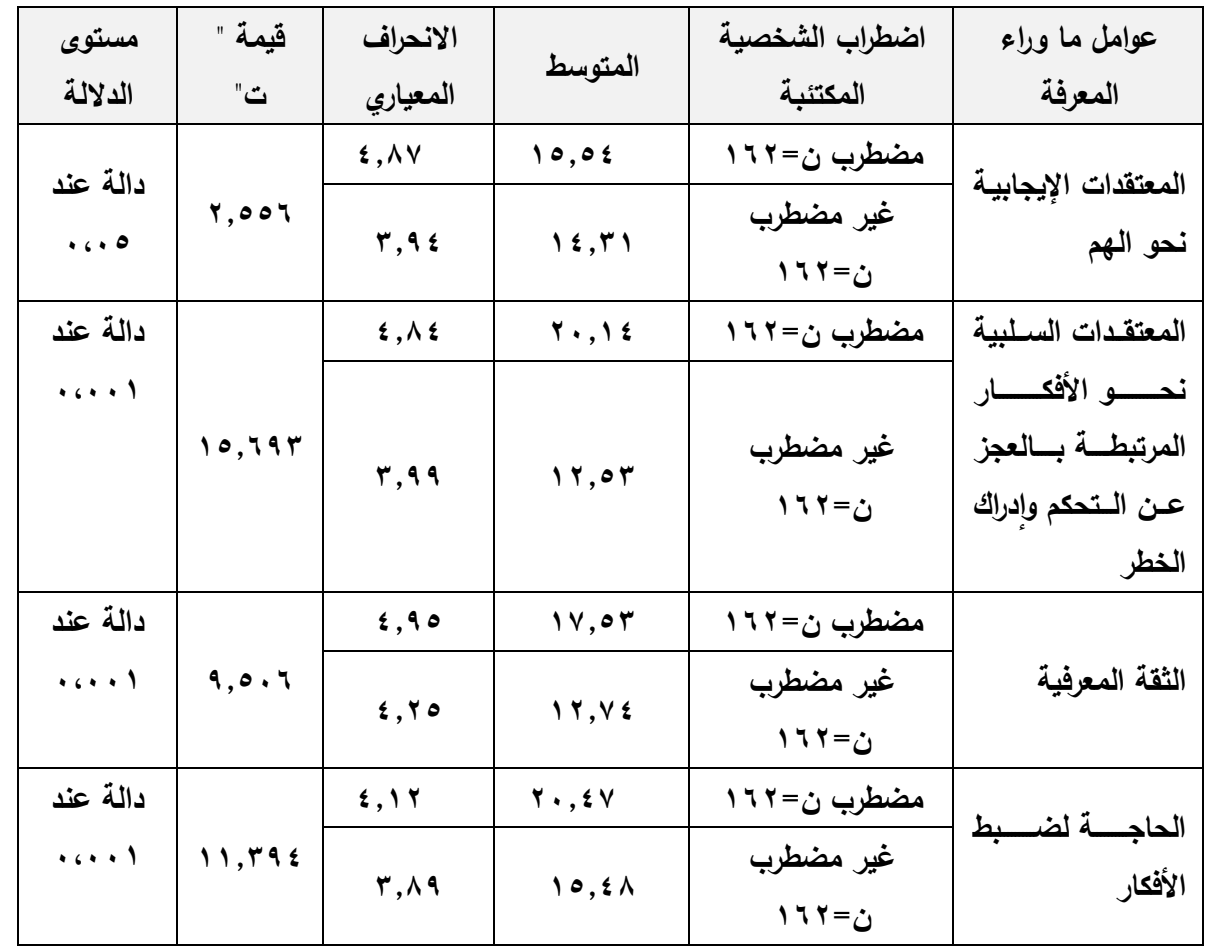

DOI: $\quad 10.12816 / 0051446$ 


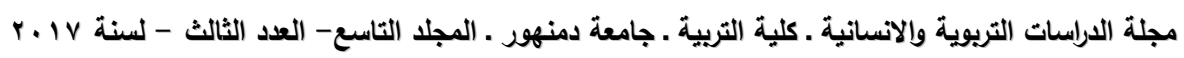

\begin{tabular}{|c|c|c|c|c|c|}
\hline \multirow{2}{*}{ دالة عند } & \multirow[b]{2}{*}{ r r r } & $\varepsilon, 9 r$ & $r \cdot, r t$ & مضطرب ن=r r 19 & \multirow{2}{*}{ بالذات الـوعي أو الثــور } \\
\hline & & $\leqslant, 0 \leqslant$ & Mr, I & غير مضطرب & \\
\hline \multirow{2}{*}{ دالة عند } & \multirow[b]{2}{*}{ Ir,oor } & $14, .7$ & $94,9 \leq$ & مضطرب ن=r I 1 r & \multirow[b]{2}{*}{ الدرجة الكلية } \\
\hline & & $11, r^{\prime}$ & $V V, Y$. & غير مضطرب & \\
\hline
\end{tabular}

\section{يتضح من الجدول السابق ما يلي:}

وجود فروق ذات دلالة إحصائية بين درجات(مضطربي الثخصية الدكتئبة - غير

المضطربين) علي عوامل ما وراء المعرفة (المعتقدات الايجابية نحو الهم - المعتقدات

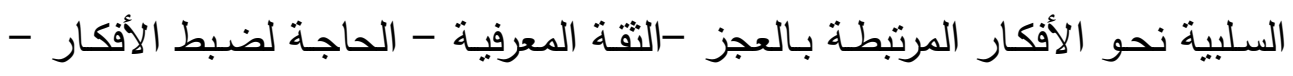

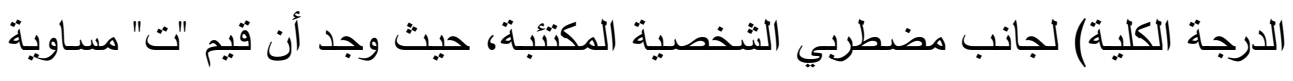

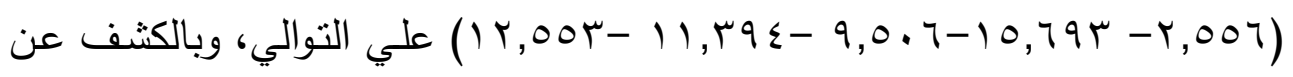

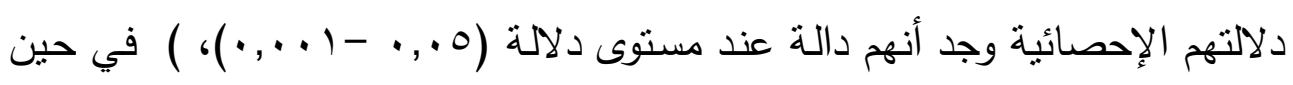

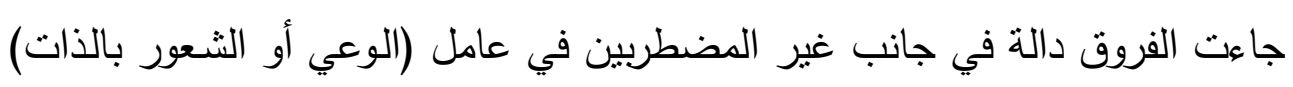

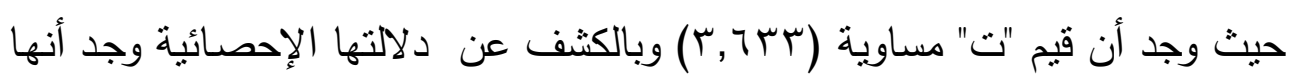

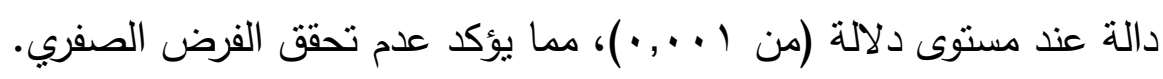

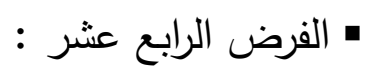

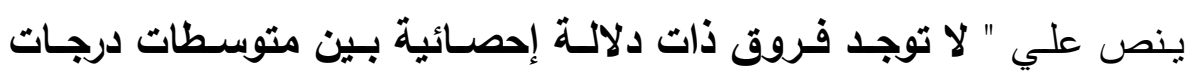

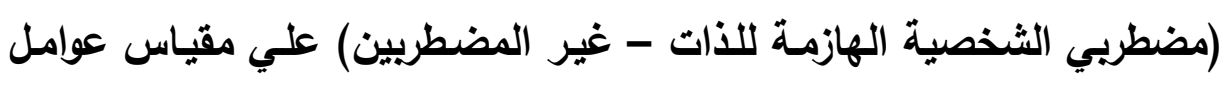

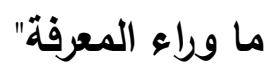

لاختبار صحة الفرض السابق استخدم اختبار "ت" لدلالة الفروق بين

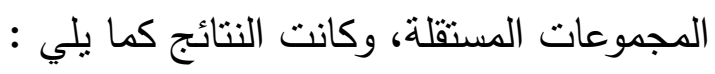


عوامل ما وراء المعرفة ودورها في اضطرابات الثخصية د. قطب عبده خليل حنور د. دحمود مغازي العطار

جدول (r) قيمـة "ت" ودلالتها الإحصـائية بين بين متوسطات درجات (مضطربي

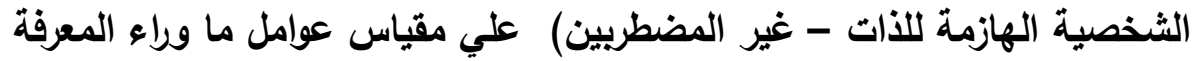

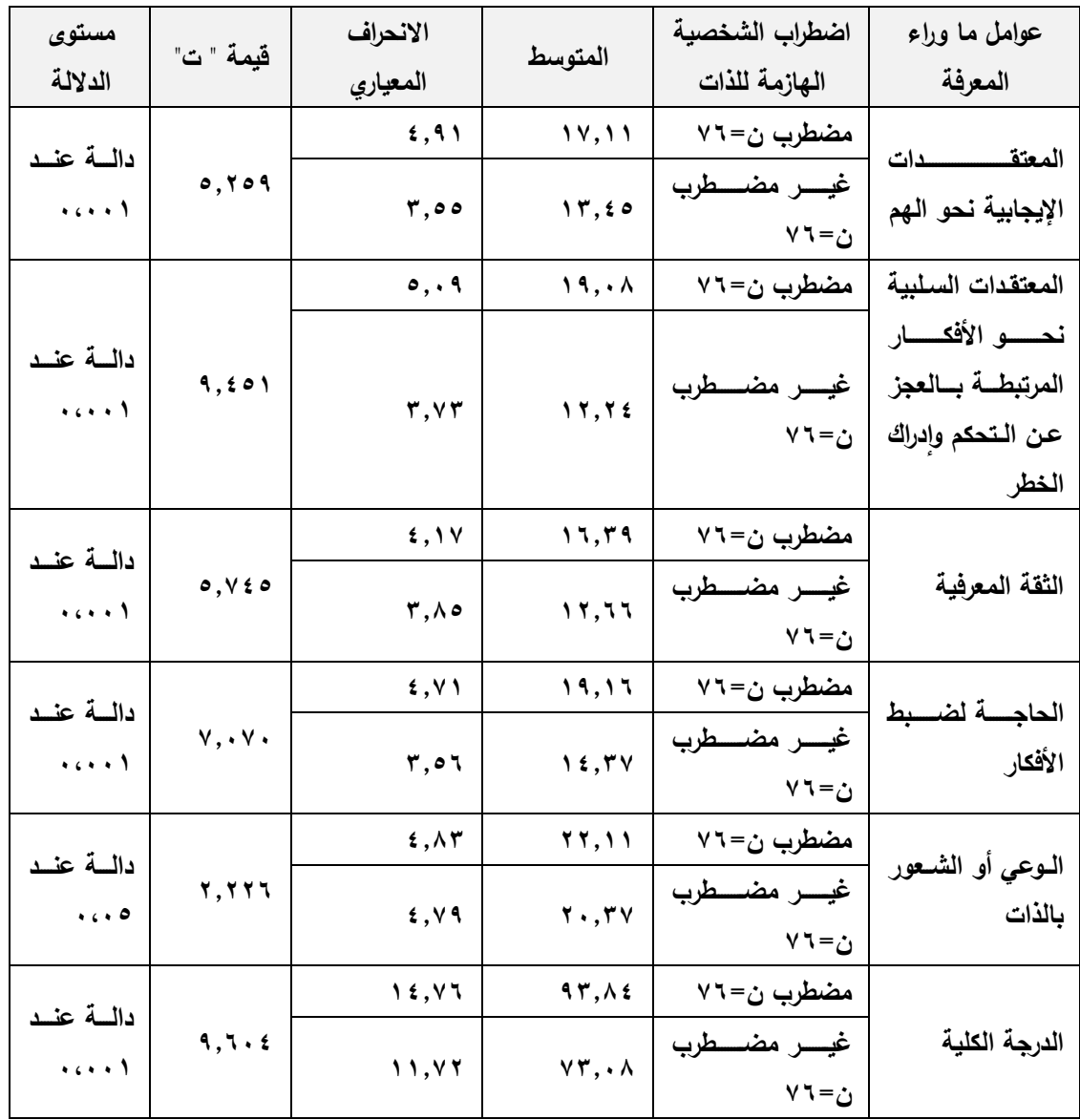

يتضح من الجدول السابق ما يلي:

وجود فروق ذات دلالة إحصائية بين درجات(مضطربي الثخصية الهازمة للذات غير المضطربين) علي عوامـل مـا وراء المعرفـة (المعتقدات الايجابيـة نحو الهمالمعتقدات السلبية نحو الأفكار المرتبطة بالعجز -التقة المعرفية - الحاجـة لضبط

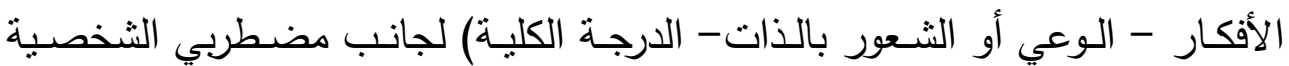

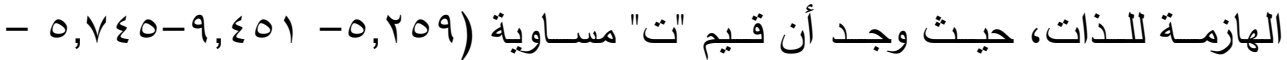

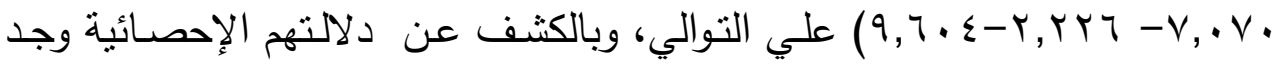




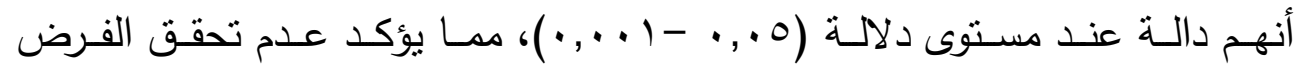
الصفري.

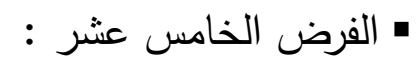

ينص علي " لا توجد فـروق ذات دلالــة إحصـائية بـين متوسـطات درجـات

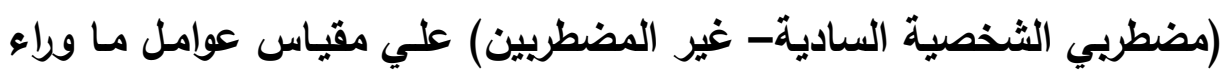

المعرفةة"

لاختبار صحة الفرض السابق استخدم اختبار "ت" للالآة الفروق بين

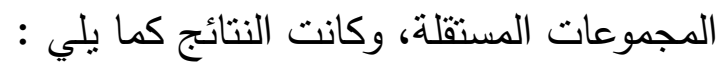

جدول (ץ) قيمة "ت" ودلالتها الإحصائية بين بين متوسطات درجات (مضطربي

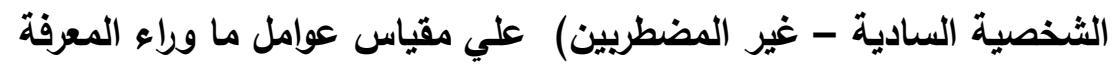

\begin{tabular}{|c|c|c|c|c|c|}
\hline ى الدلالة مستو & " قيمة & الانحراف & المتوسط & الشخصية السادية & عوامل ما وراء \\
\hline \multirow{2}{*}{ الـ، دالـة عنــ } & \multirow{2}{*}{$r, \ldots r$} & $r, \cdot r$ & $\mid 7, v 1$ & مضطرب ن=؛ 1 & \multirow{2}{*}{ نحو الهعت } \\
\hline & & $r, r \cdot$ & $|r, v|$ & غير مضطرب ن=؛ 1 & \\
\hline \multirow[b]{2}{*}{ غير دالة } & \multirow[b]{2}{*}{$r, \ldots r$} & $r, .9$ & $1 \leq, \ldots$ & مضطرب ن=؛ 1 & \multirow{2}{*}{ الأفكار المرتبطة بـالعجز السلبية نحو } \\
\hline & & $r, r r$ & $11,0 \mathrm{~V}$ & غير مضطرب ن=؛ 1 & \\
\hline \multirow{2}{*}{ غير دالة } & \multirow{2}{*}{$\cdot, 001$} & $r, r v$ & $1 r, \ldots$ & مضطرب ن=ء 1 & \multirow{2}{*}{ الثقة المعرفية } \\
\hline & & 1,91 & IT,OV & غير مضطرب ن=؛ 1 & \\
\hline \multirow{2}{*}{ غير دالة } & \multirow{2}{*}{$1, r \leq r$} & $\varepsilon, \diamond \mathrm{V}$ & $17, \ldots$ & مضطرب ن=ء 1 & \multirow{2}{*}{ الحاجة لضبط الأفكار } \\
\hline & & $r, q r$ & $1 \leqslant, \ldots$ & غير مضطرب ن=ع 1 & \\
\hline \multirow{2}{*}{ غير دالة } & \multirow{2}{*}{$\cdot, \leqslant \vee 0$} & $0, r$. & $r \cdot, v_{1}$ & مضطرب ن= \& 1 & \multirow{2}{*}{ بالذات الـــوعي أو الثــــور } \\
\hline & & $0,9 r$ & r I,V & غير مضطرب ن=\& | & \\
\hline \multirow{2}{*}{ غير دالة } & \multirow{2}{*}{ 1, АтV } & $v, r \leq$ & $\Lambda \cdot, \leqslant \Gamma$ & مضطرب ن=\& 1 & \multirow{2}{*}{ الارجة الكلية } \\
\hline & & 9,17 & $V \leqslant, \Delta V$ & غير مضطرب ن=؛ 1 & \\
\hline
\end{tabular}

يتضح من الجدول السابق ما يلي:

عدم وجود فروق ذات دلالة إحصائية بين درجات(مضطربي الثخصية السادية -

غير المضطربين) علي عوامـل مـا وراء المعرفـة (المعتقدات السلبية نحـو الأفكار 
المرتبطــة بـالعزز -التقـة المعرفيـة - الحاجـة لضـبط الأفكار - الـوعي أو الثـعور

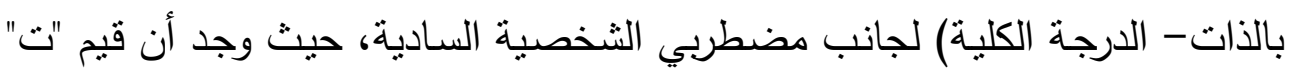
مسـاوية (r ., , ب-

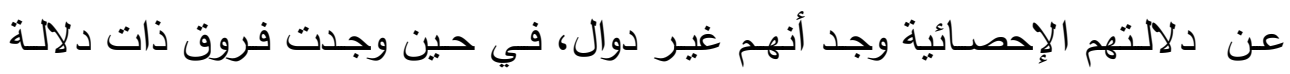
إحصائية في عامل (المعتقدات الايجابية نحو الهم) حيث وجد أن قيم "ت" مساوية

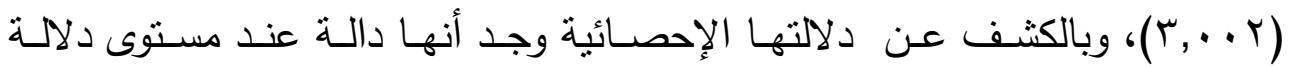

(0. (•) )، مما يؤكد عدم تحقق الفرض الصفري.

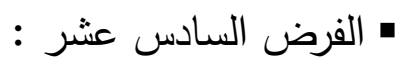

ينص علي " لا توجد فـروق ذات دلالــة إحصـائية بـين متوسـطات درجـات

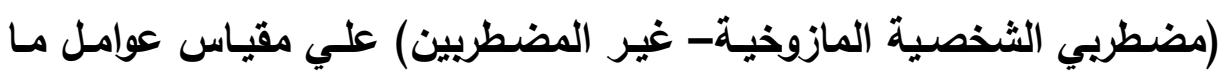

وراء المعرفة" - ومعطية

لاختبار صحة الفرض السابق استخدم اختبار "ت" لدلالة الفروق بين

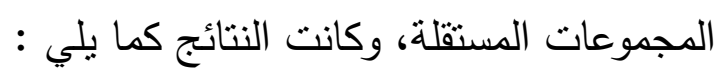

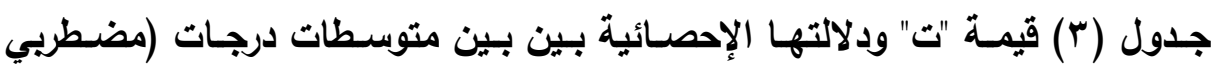

\begin{tabular}{|c|c|c|c|c|c|}
\hline مسـتوى & تيمـة " & 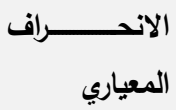 & المتوسط & 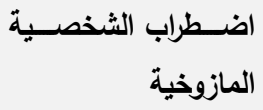 & عوامــــل مــــــا وراء \\
\hline \multirow{2}{*}{ دالـة عند } & \multirow{2}{*}{ r,rrq } & \&,Or & $1 \wedge, \cdot \varepsilon$ & مضطرب ن= r = & \multirow{2}{*}{ الهمت المتقدات الإيجابيـة نحـو } \\
\hline & & $r, \wedge 1$ & $|0, \mu|$ & غير مضطرب ن= = به & \\
\hline \multirow[b]{2}{*}{ غير دالة } & \multirow[b]{2}{*}{$\cdot, r \vee \wedge$} & 0,7 & $17, \cdot \varepsilon$ & مضطرب ن= & \multirow{2}{*}{ 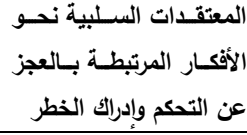 } \\
\hline & & $0, T V$ & 17,40 & غير مضطرب ن= = & \\
\hline \multirow{2}{*}{ غير دالة } & \multirow[b]{2}{*}{$1, .9 r$} & $0, Y \wedge$ & $1 \leq, \ldots$ & مضطرب ن = r P & \multirow{2}{*}{ الثقة المعرفية } \\
\hline & & 0,74 & $10,1 \mathrm{~V}$ & غير مضطرب ن= = & \\
\hline \multirow{2}{*}{ غير دالة } & \multirow[b]{2}{*}{., 704} & $0,0 Y$ & $1 \mathrm{~V}, \leqslant \mathrm{~T}$ & مضطرب ن = P O & \multirow{2}{*}{ لحاجة لضبط الأفكار } \\
\hline & & $\varepsilon, 9 Y$ & $1 \Lambda, 1 \mu$ & غير مضطرب ن= = & \\
\hline \multirow{2}{*}{ غير دالة } & \multirow{2}{*}{$\cdot, \leqslant 79$} & $\varepsilon, 9$ & $r 1, \ldots$ & مضطرب ن = r P & \multirow{2}{*}{ الوعي أو الثعور بالذات } \\
\hline & & $\varepsilon, r \varepsilon$ & $r 1, \leqslant r$ & غير مضطرب ن= = & \\
\hline \multirow{2}{*}{ غير دالة } & \multirow{2}{*}{$\cdot, \cdot 0}$. & 17,70 & $\wedge \uparrow, 0 \leqslant$ & مضطرب ن = r P & \multirow{2}{*}{ الارجة الكلية } \\
\hline & & $1 \leqslant, r 4$ & $\Lambda \uparrow, r \wedge$ & غير مضطرب ن = Y & \\
\hline
\end{tabular}
الثخصية المازوخية - غير المضطربين) علي مقياس عوامل ما وراء المعرفة

DOI: $\quad 10.12816 / 0051446$ 


\section{يتضح من الجدول السابق ما يلي:}

عدم وجود فروق ذات دلالة إحصائية بين درجات (مضطربي الثخصية المازوخية - غير المضطربين) علي عوامل مـا وراء المعرفة (المعتقدات السلبية نحو الأفكار المرتبطـة بـالعجز -اللقــة المعرفيـة - الحاجـة لضـبط الأفكار - الـوعي أو الثـعور بالذات- الدرجة الكليـة) لجانب مضطربي الثخصية المازوخيـة، حيث وجد أن قيم

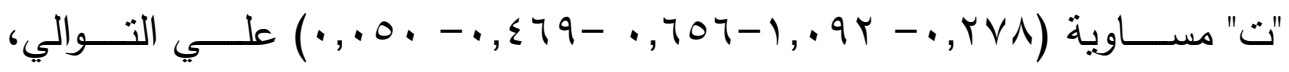
وبالكثف عن دلالتهم الإحصائية وجد أنهم غير دوال، في حين وجدت فروق ذات دلالـة إحصـائية في عامل (المعتقدات الايجابية نحو الهم) حيـث وجد أن قيم "ت" مساوية (q بr,r)، وبالكثف عن دلالتها الإحصائية وجد أنها دالة عند مستوى دلالة ( ( . , •). مما يؤكد عدم تحقق الفرض الصفري. مناقشة وتفسير نتائج الدراسة:-

\section{أولا: بالنسبة لعامل المعتقدات الايجابية نحو الهم:-}

جـاءت النتـائج لتؤكـد علـي أن ذوي اضـطرابات الثخصـية البارانوبديـة، شـبه الفصامية، النرجسية، الوسواسية القهريـة، السلبية العدوانية، المكتئبة، الهازمـة للذات، السـادية، المازوخيـة لديهه إعتقاد بـأن المثابرة علي التفكير المرتبط بـالهم والانزعاج يساعد علي حل المشكلات الخاصة بهم ويكون مفيد بالنسبة لهم. فبالنسبة للشخصية البارانويدية تتمنل هذه المعتقدات في أنه لابد ان يكون شخص مرفوض لأنه شخص متميز ولذلك يرفضه الآخرون وأنه بجب عليه ان لا بغفر أي إهانات أو جروح لأنه شخصية متميزة ولا يجب أن يحدث معها مثل هذه الإهانات أو الجروح. وبالنسبة للشخصسية شبه الفصسامية تتمثل هذه المعتقدات في أن البعد عن الناس وتجنبهم بسبب الراحة وان العزلة وعدم إقامة أي علاقات اجتماعية مع الآخرين سوف تجعلني أتجنب الكثير من المشكلات والخسائر • وبالنسبة للشخصية النرجسية تتشثل هذه المعتقدات في أنها يجب أن تحصل علي الإعجـاب الثـديد من كل المحيطين بها وأنها شخصية ناجحة بشكل غير محدود رغم قدراتها وإمكانياتها العادية في كثير من 
الأحيان. وبالنسبة للشخصية الوسواسية القهرية تتمثل هذه المعتقدات في أن التدقيق

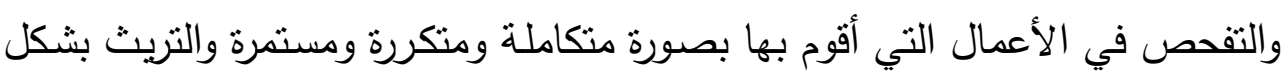

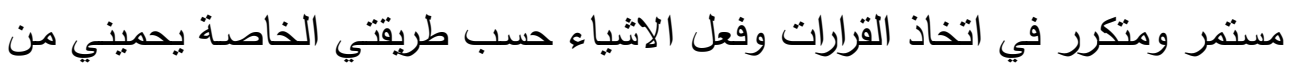

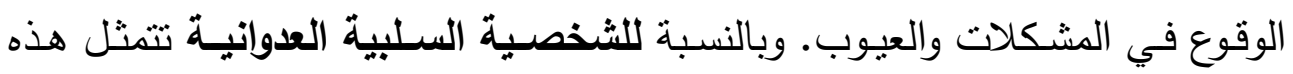

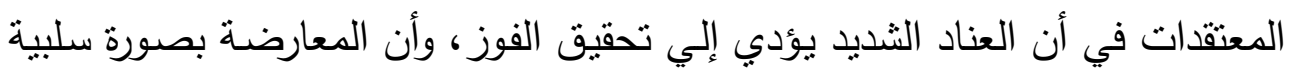

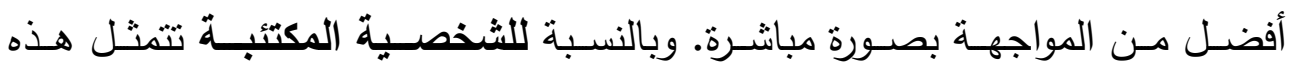
المتقدات في أن الحزن المستمر ونقد الذات بصورة هدامة ومتكررة والثعور بالذنب باستمرار يساعد في حل المشكلات. وبالنسبة للثخصية الهازمـة للذات تتمثل هذه ونه

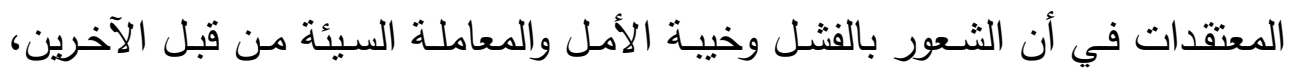
وكذلك التضـحية بنفسي يسـاعدني في مواجهة المشكلات بصسورة أفضل. وبالنسبة للشخصية السادية تتمنل هذه المعتقدات في أن تعذيب الآخرين سواء بصورة جسدية

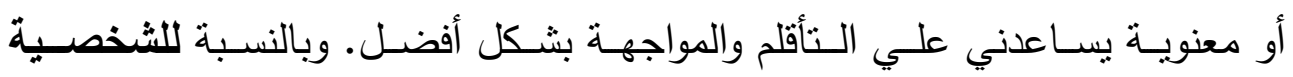
المازوخيـة تتمثل هذه المعتقدات في أن تعذيب الآخرين له سواء بصورة جسدية أو

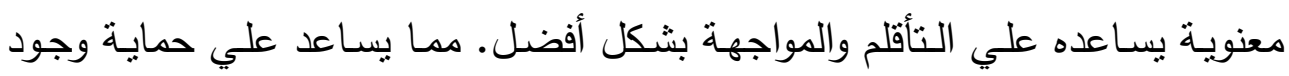
المعتقدات الخاصة بطبيعة كل نوع من أنواع اضطرابات الثخصية السابقة.

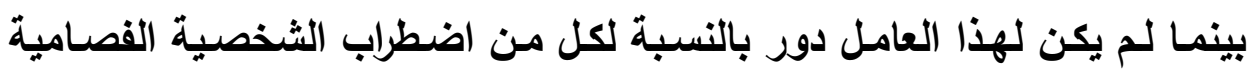

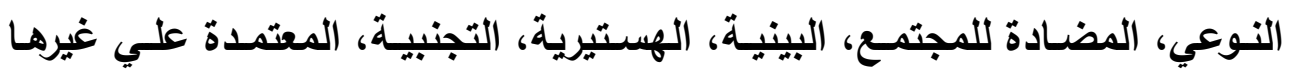
فبالنسبة للشخصية الفصامية النوعي فهي منعزلة بصورة كبيرة عن الواقع دون وعي منها بـذلك مما يؤكد علي عدم وجود معتقدات إيجابيـة نحو الهم لديها. وبالنسبة للشخصية المضـادة للمجتمـع فهي تري أن من حقها الحصـول ممتلكات الآخرين والاعتداء عليهم من أجل الاستمتاع بها. وبالنسبة للشخصية البينية فهي تعيش في نري

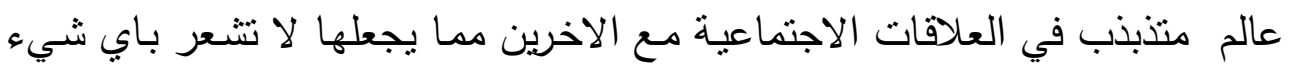

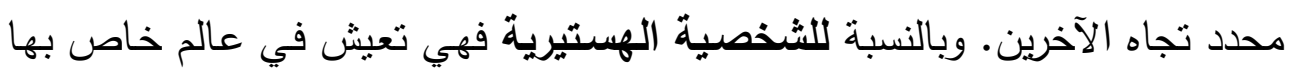
يمتاز بالأنانية المطلقة والحب المطلق للذات والسعي بكافة الطرق لتحقيق أهدافها.

DOI: $10.12816 / 0051446$ 
وبالنسبة للشخصية التجنبيـة فهي شخصية ذات علاقات تكاد تكون غير موجودة علي أرض الواقع نتيجة التوتز والتوجس باستمرار مما يجعلها شبه و وحيدة باستمرار .

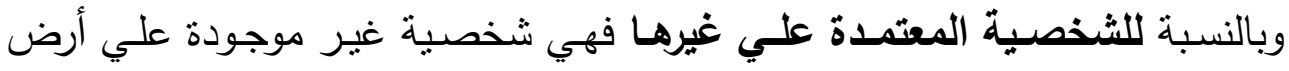

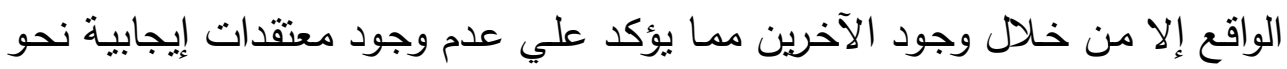
الهم لاي اضطرابات الثخصية السابقة. ثانياً: بالنسبة لعامل المعتقات السلبية نحو الأفكار المرتبطة بالعجز عن التحكم وإدراك الخطر :جاءت النتائج لتؤكد علي أن ذوي اضطرابات الثخصية الفصامية النوعي، شبه

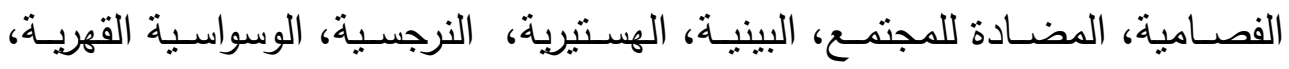

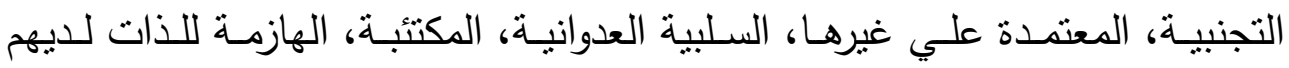

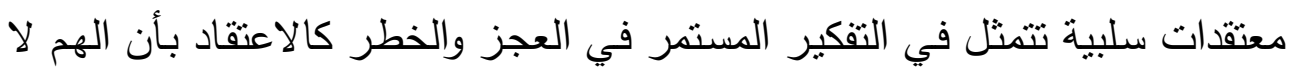
يمكن السيطرة عليه ـ فبالنسبة للشخصية الفصامية النوعي فهي تعتقد أن العلاقات الاجتماعية وإقامة علاقات وثثقة مع الآخرين تجعل الفرد يدخل في مشكلات وأخطار

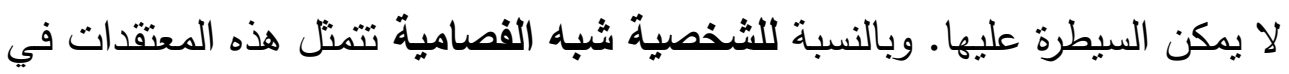

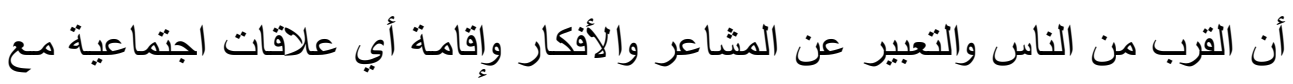
الآخرين سوف تجعلني أتعرض للكثير من المشكلات والخسائر التي لا بمكن السيطرة عليها. وبالنسبة للثخصية المضـادة للمجتمع تثمثل هذه المعتقدات في عدم قدرتها علي التخلص من الرغبة في الحصول علي ممتلكات الآخرين والاعتداء عليهم. وبالنسبة للشخصية البينية تتمثل هذه المعتقدات في عدم قدرتها وعجزها علي إقامة

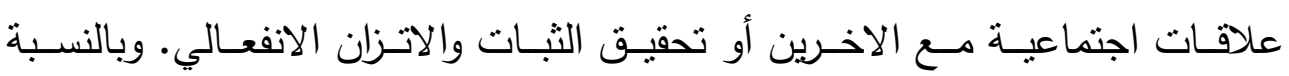
للشخصية الهستيرية تتمثل هذه المعتقدات في الثعور بالعجز حيال تكوين علاقات الات

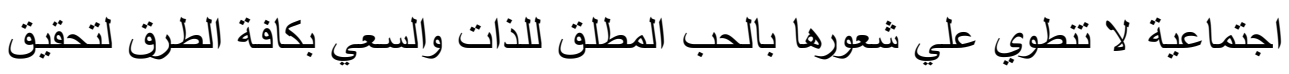

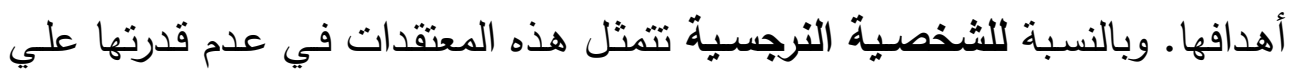
التخلص من الإعجاب الثديد من كل المحيطين بها وأنها شخصية ناجحة بشكل غير 
محدود رغم قدراتها وإمكانياتها العاديـة في كثير من الأحيان. وبالنسبة للشخصية الوسواسية القهريـة تتمثل هذه المعتقدات في عدم قدرتها علي تجاهل أفكارها بشأن التتقيق والتفحص في الأعمال التي تقوم بها بصورة متكاملة ومتكررة ومستمرة وفعل الاشياء حسب طريقتها الخاصة. وبالنسبة للشخصية التجنبية تتمثل هذه المعتقدات في عدم قدرتها وعجزها علي إقامة علاقات اجتماعية علي أرض الواقع نتيجة التوتر

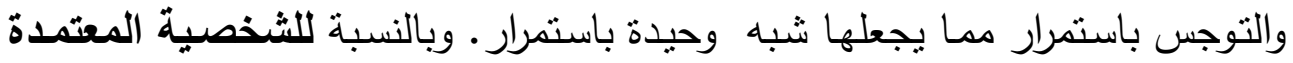
علي غيرها تتمنل هذه المعتقدات في الثعور بالخوف والفزع وعدم قدرتها علي القيام

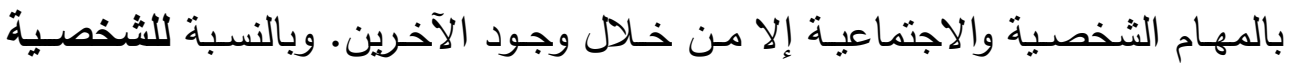
السلبية العدوانية تتمثل هذه المعتقدات في عدم القدرة علي التحكم في الرغبة القوية التئة

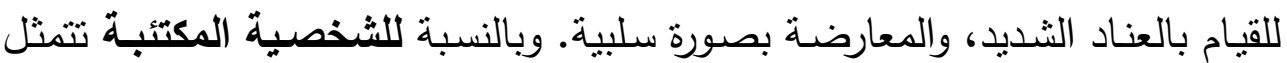
هذه المعتقدات في عدم القدرة علي تجاهل أفكار الحزن المستمر ونقد الذات بصورة هدامة ومتكررة والثعور بالذنب باستمرار • وبالنسبة للشخصية الهازمـة للذات تتمثل

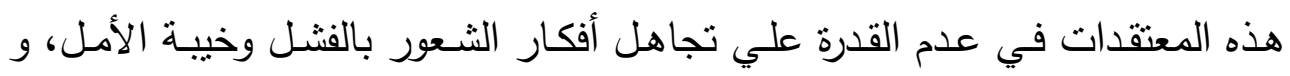
المبالغة في التضحية بالنفس مما يساعد علي حماية وجود المعتقدات الخاصة بطبيعة كل نوع من أنواع اضطرابات الشخصية السابقة. بينما لم يكن لهذا العامل دور بالنسبة لكل من اضطراب الثخصية البارية النويدية،

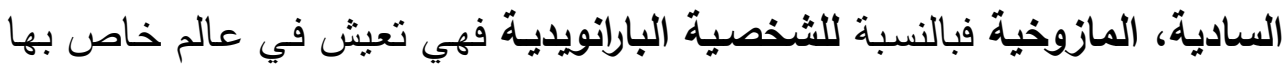
يمتاز بالأنانية المطلقة والحب المطلق للذات والسعي بكافة الطرق لتحقيق أهدافها. وبالنسبة للشخصية السادية فهي تعيش من خلال الاعتقاد بأن تعذيب الآخرين سواء

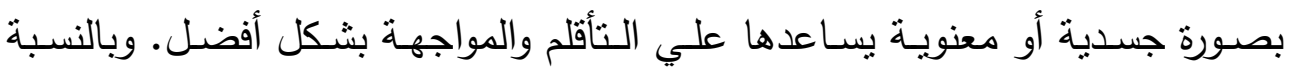
للثخصية المازوخية فهي تعيش من خلاد الاعتقاد بأن تعذيب الآخرين لها سواء

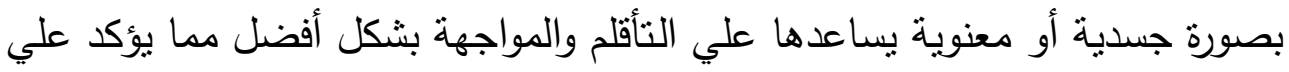
عدم وجود معتقدات سلبية نحو الأفكار المرتبطة بالعجز عن التحكم وإدراك الخطر لدي اضطرابات الثخصية السابقة. 
ثالثاً: بالنسبة لعامل الثقة المعرفية:-

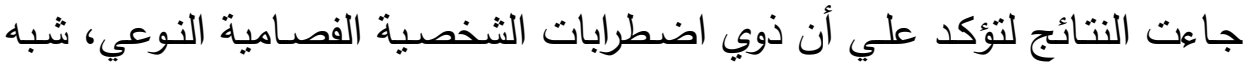
الفصامية، المضادة للمجتمع، البينية، الهستيرية، النرجسية، التجنبية، المعتمدة علي لئي غيرها، السلبية العدوانية، المكتئبة، الهازمة للذات لديهم افتقار في التقة المعرفية تتمثل في الاعتقاد في عدم الثقة في ذاكرته وانتباهه. فبالنسبة للشخصية الفصامية النوعي فهي تعتقد بعدم الثقة في الذاكرة والانتباه وهو ما يؤثر في العلاقات الاجتماعية وإقامة علاقات وثيقة مع الآخرين. وبالنسبة للشخصية شبه الفصامية فهي تعتقد بعدم الثقة في الذاكرة والانتباه وهو ما يؤثر في القرب من الناس والتعبير عن المشـاعر والأفكار

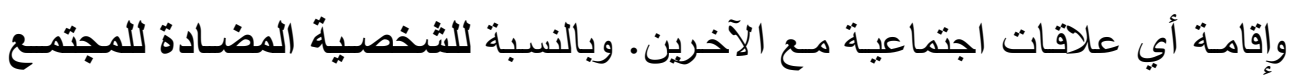
فهي تعتقد بعدم التقة في الذاكرة والانتباه وهو ما يؤثر في عدم قدرتها علي التخلص

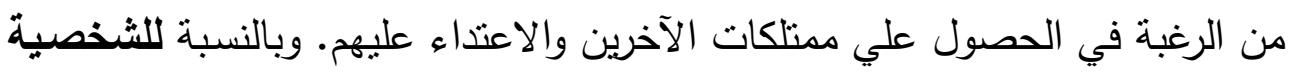
البينيـة فهي تعتقد بعدم التقة في الذاكرة والانتباه وهو مـا يؤثر في إقامـة علاقات

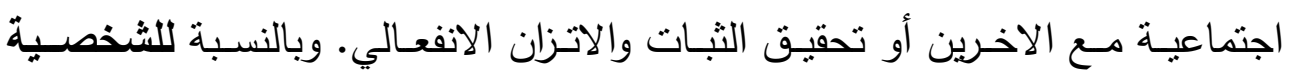

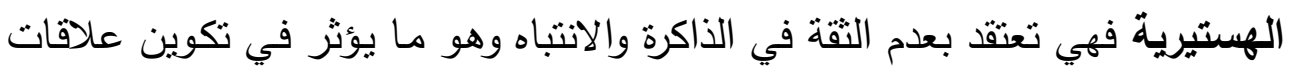
اجتماعية لا تتطوي علي شعورها بالحب المطلق للذات والسعي بكافة الطرق لتحقيق

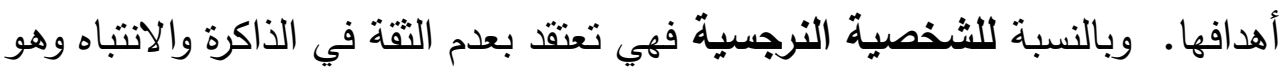
ما يؤثر في عدم قدرتها علي التخلص من الإعجاب الثديد من كل المحيطين بها وأنها شخصية ناجحة بشكل غير محدود رغم قدراتها وإمكانياتها العادية في كثير من هن الأحيان. وبالنسبة للشخصية التجنبية فهي تعتقد بعدم الثقة في الذاكرة والانتباه وهو

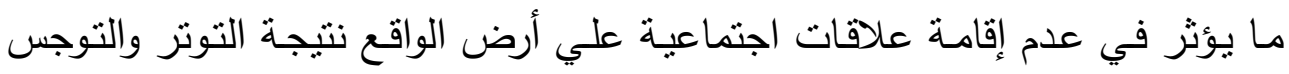
باستمرار مما يجعلها شبه وحيدة باستمرار • وبالنسبة للشخصية المعتمدة علي غيرها فهي تعتقد بعدم التقة في الذاكرة والانتباه وهو ما يؤثر في قدرتها علي القيام بالمهام

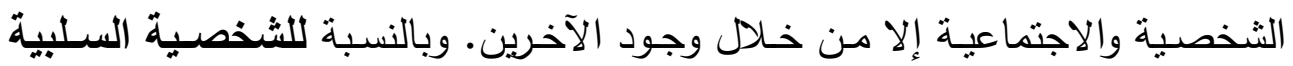
العدوانية فهي تعتقد بعدم التقة في الذاكرة والانتباه وهو ما يؤثر في استمرارية الرغبة ولية 
القويـة للقبام بالعناد الثنديد، والمعارضـة بصورة سلبية. وبالنسبة للشخصية المكتئبـة فهي تعتقد بعدم الثقة في الذاكرة والانتباه وهو ما يؤثر في استمرار أفكار الحزن ونقد

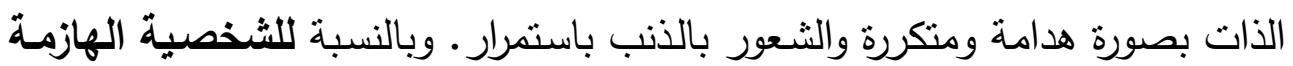

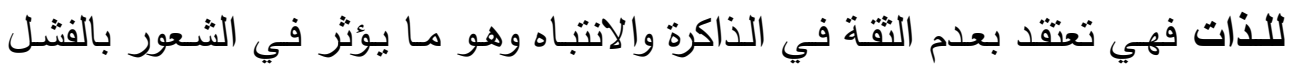
وخيبة الأمل، و المبالغة في التضحية بالنفس مما يساعد علي حماية وجود المعتقدات الخاصة بطبيعة كل نوع من أنواع اضطرابات الثخصية السابقة. بينما لم يكن لهزا العامل دور بالنسبة لكل من اضطراب الباراتويدية، الوسواسية أواسية

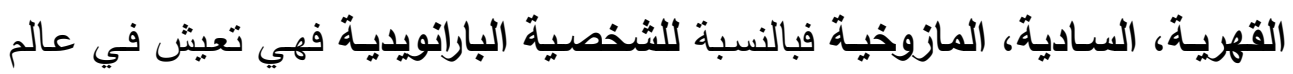
خاص بها يمتاز بالأنانية المطلقة والحب المطلق للذات والسعي بكافة الطرق لتحقيق أهدافها. وبالنسبة للثخصية الوسواسية القهرية فهي تعيش في عالم يمتاز بالتدقيق بالنه والتفحص في الأعمال التي ثقوم بها بصورة متكاملة ومتكررة ومستمرة وفعل الاشياء

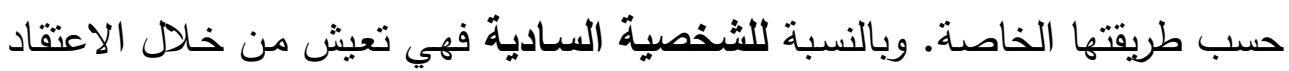
بأن تعذيب الآخرين سواء بصورة جسدية أو معنوية يساعدها علي التأقلم والمواجهة

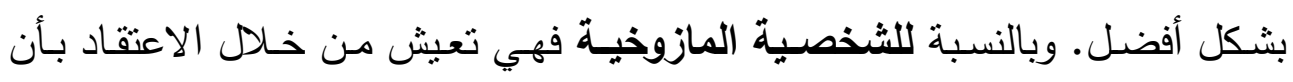
تعذيب الآخرين لها سواء بصورة جسدية أو معنوية بساعدها علي التأقلم والمواجهة

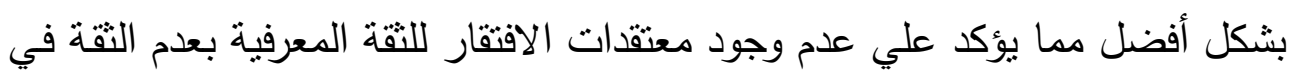
الذاكرة والانتباه لاي اضطرابات الثخصية السابقة. رابعاً: بالنسبة لعامل الحاجة لضبط الأفكار:جاءت النتائج لتؤكد علي أن ذوي اضطرابات الثخصية البارانويديـة، الفصـامية

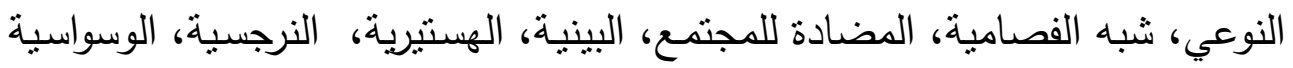

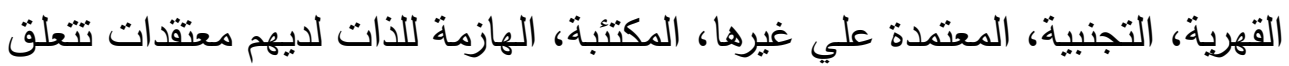
بضرورة قمع الأفكار أو تجنبها والسيطرة عليها. فبالنسبة للثخصية البارانويدية تتمثل هذه المعتقدات في أنها كثيراً مـا تفكر في أفكار مثل أنها شخصية مرفوضئة فئة لأنها

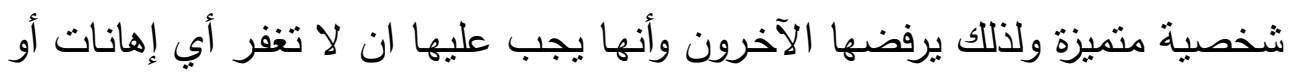

DOI: $10.12816 / 0051446$ 
جروح لأنها شخصية منميزة. وبالنسبة للشخصية الفصامية النوعي فهي تعتقد أنه

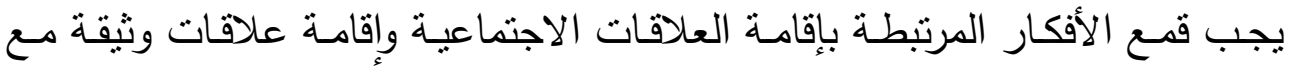
الآخرين. وبالنسبة للشخصية شبه الفصامية تتمثل هذه المعتقدات في ضرورة تجنب الأفكار المتعلقة بالقرب من الناس والتعبير عن المشاعر والأفكار وإقامة أي علاقاتهات فئه فئه

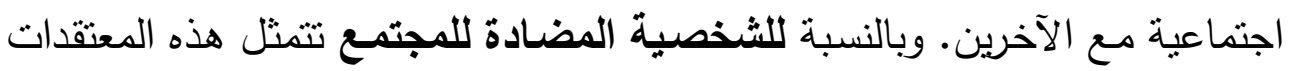
في ضرورة قمع الأفكار المرتبطة بعدم القدرة علي التخلص من الرغبة في الحصول

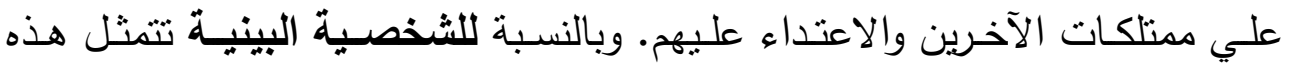
المعتقدات في ضرورة السيطرة علي الأفكار المرتبطة بعدم قدرتها وعجزها علي إقامة

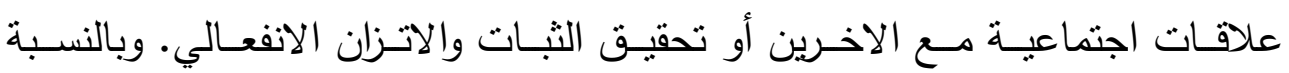
للشخصية الهستيرية تتمثل هذه المعتقدات في ضرورة قمع الأفكار المرتبطة بالثعور بالعجز حيال تكوين علاقات اجتماعية لا تتطوي علي شعورها بالحب المطلق للذات

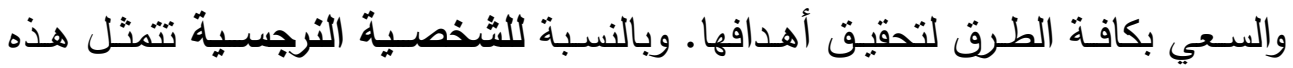
المعتقدات في ضرورة السيطرة علي الأفكار المرتبطة بعدم قدرتها علي التخلص من التهابه

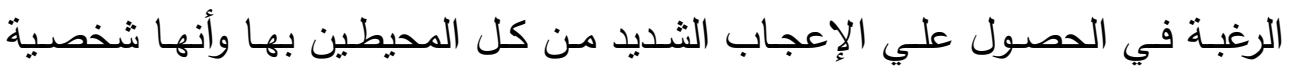
ناجحة بشكل غير محدود رغم قدراتها وإمكانياتها العاديـة في كثير من الأحيـان.

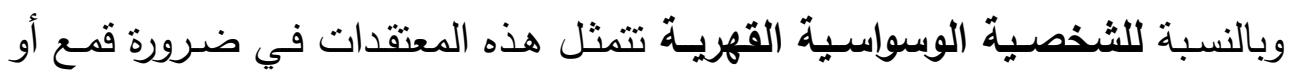
تجنب الأفكار المرتبطة بعدم قدرتها علي تجاهل أفكارها بشأن التدقيق والتفحص في الأعمال التي تقوم بها بصورة متكاملة ومتكررة ومستمرة وفعل الاشياء حسب طريقتها

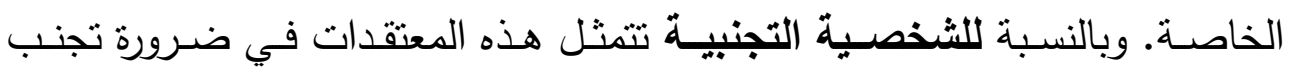
الأفكار المرتبطة بعدم قدرتها وعجزها علي إقامة علاقات اجتماعية علي أرض الواقع

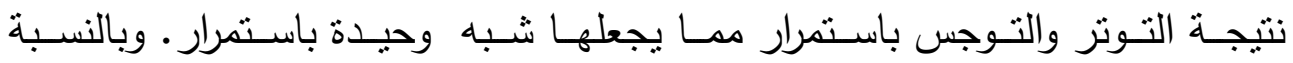

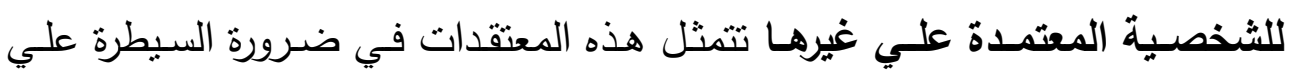
الأفكار المرتبطة بالثعور بالخوف والفزع وعدم قدرتها علي القيام بالمهام الثخصية

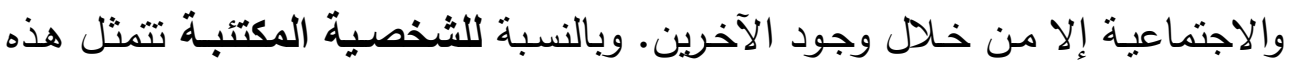


المعتقدات في ضرورة السيطرة علي الأفكار المرتبطة بعدم القدرة علي تجاهل أفكار الحزن المستمر ونقد الذات بصورة هدامة ومتكررة والثعور بالذنب باستمرار • وبالنسبة للشخصية الهازمـة للذات تتمثل هذه المعتقدات في ضرورة تجنب الأفكار المرتبطة بعدم القدرة علي تجاهل أفكار الثعور بالفشل وخيبة الأمل، و المبالغة في التضحية بالنفس مما بساعد علي حمايـة وجود المعتقدات الخاصـة بطبيعة كل نوع من أنواع اضطرابات الثخصية السابقة.

بينمـا لـم يكن لهذا العامل دور بالنسبة لكل مـن اضطراب الثخصية السلبية

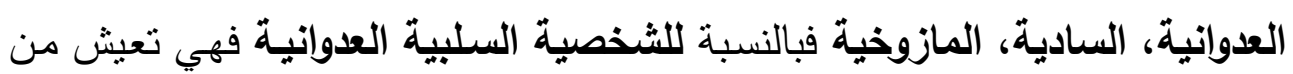

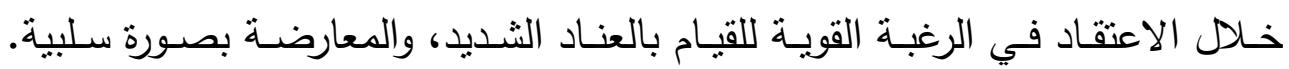

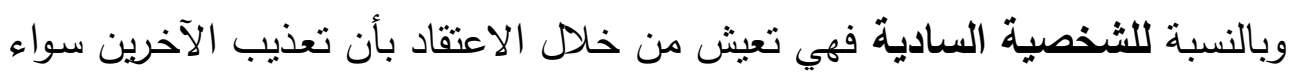

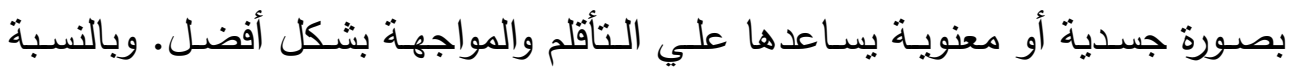
للثخصية المازوخية فهي تعيش من خلاد الاعتقاد بأن تعذيب الآخرين لها سواء

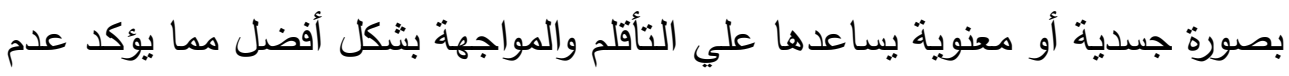
وجود معتقدات مرتبطة بالحاجة لضبط الأفكار لدي اضطرابات الثخصية السابقة.

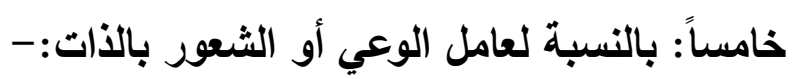

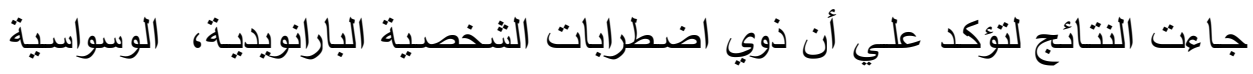

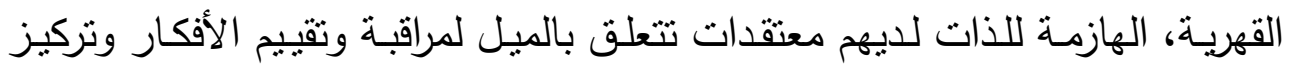

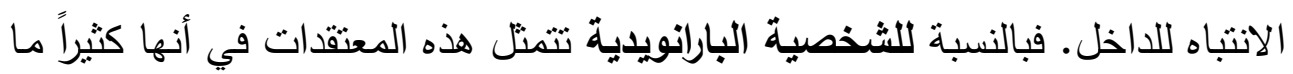
تقوم بنركيز انتباهها علي أفكار مثل أنها شخصية متميزة ولذلك برفضها الآخرون

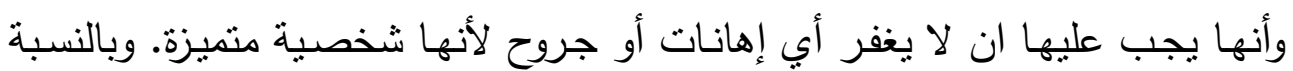
للثخصية الوسواسية القهرية تتمثل هذه المعتقات في تركيز انتباهها علي أفكارها بشأن التدقيق والتقحص في الأعمال التي تقوم بها بصورة متكاملة ومتكررة ومستمرة وفعل الاثباء حسب طريقتها الخاصة. وبالنسبة للثخصية الهازمـة للذات تتمثل هذه ونه

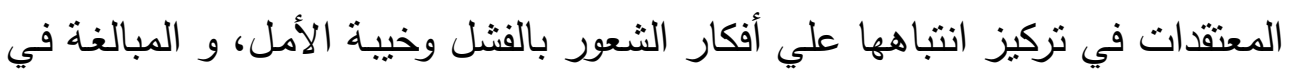

DOI: $10.12816 / 0051446$ 
التضحية بالنفس مما يساعد علي حماية وجود المعتقدات الخاصة بطبيعة كل نوع من أنواع اضطرابات الثخصية السابقة. بينما جاءت النتائج بدور معاكس لهذا العامل لكل من اضطراب الثخصية شبه الثهابه

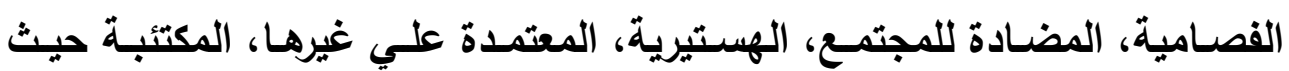
جاءت درجات غير المضطربين أعلي من درجات المضطربين بفروق ذات دلالة

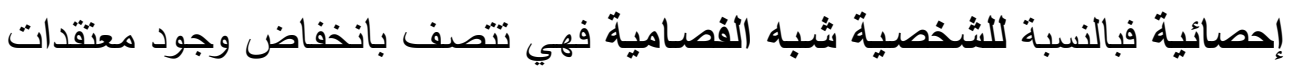
الوعي أو الثعور بالذات لايها بدرجة أقل من غير المضطربين نتيجة انفصالها عن فئه

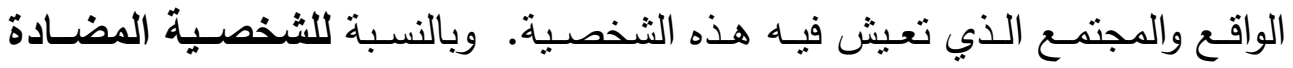
للمجتمع فهي تتصف بانخفاض وجود معتقدات الوعي أو الشعور بالذات لديها بدرجة

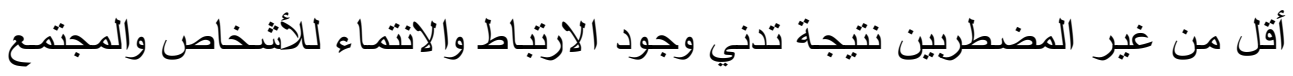

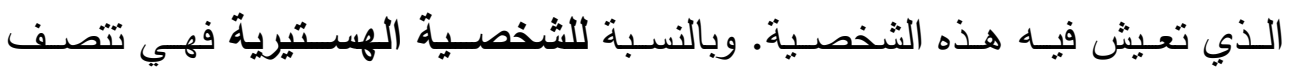

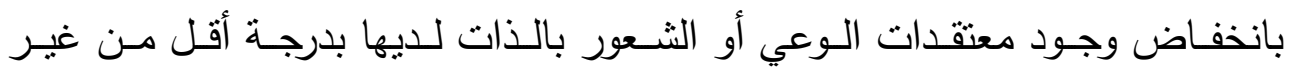

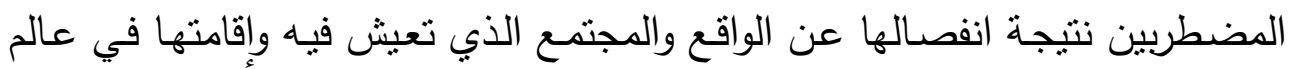

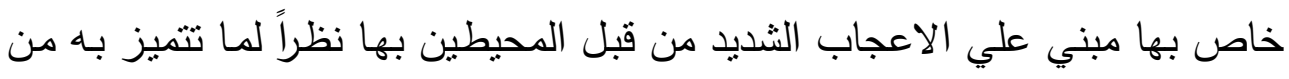
صفات وخصائص فريدة من وجهة نظرها هي فقط. وبالنسبة للشخصية المعتمدة علي غيرها فهي تتصف بانخفاض وجود معتقدات الوعي أو الثعور بالذات لديها

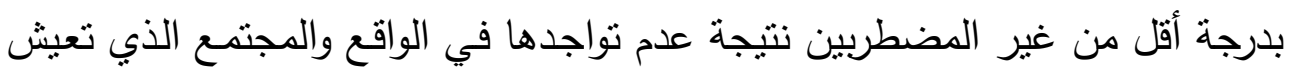

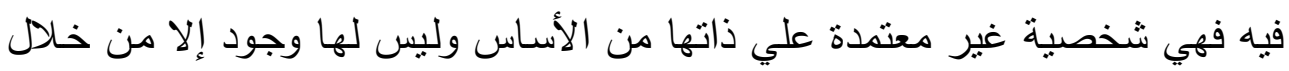

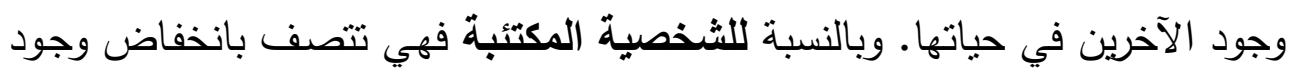

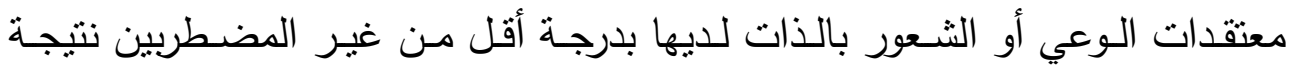
احتقارها لذاتها مما يجعلها ترفض حتي مجرد التفكير في الذات.

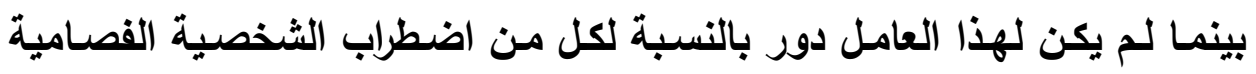

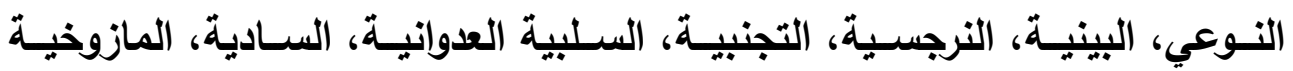
فبالنسبة للشخصية الفصامية النوعي فهي منعزلة بصورة كبيرة عن الواقع دون وعي 
منها بذللك. وبالنسبة للشخصية البينية فهي تعيش في عالم متذبذب في العلاقات الاجتماعية مع الاخرين مما يجعلها لا تشعر باي شيء محدد تجاه الآخرين. وبالنسبة

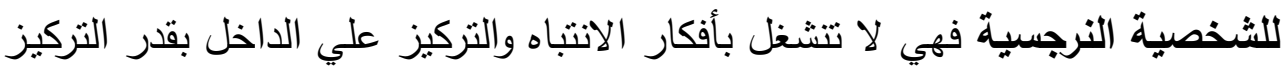
علي جذب الاهتمام والإعجاب الثديد من قبل المحيطين بها. وبالنسبة للشخصية لإنية التجنبية فهي شخصية ذات علاقات تكاد تكون غير موجودة علي أرض الواقع نتيجة

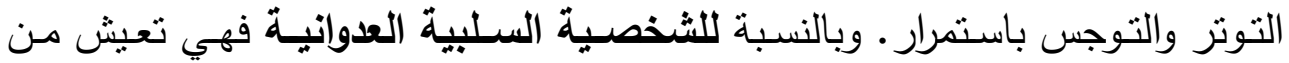
خـلال الاعتقاد في الرغبـة القويـة للقيـام بالعنـاد الثـديد، والمعارضــة بصـورة سلبية.

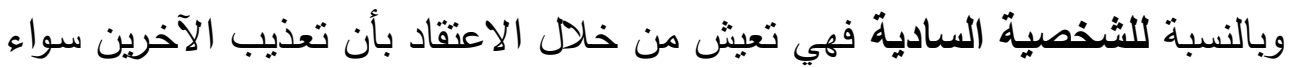

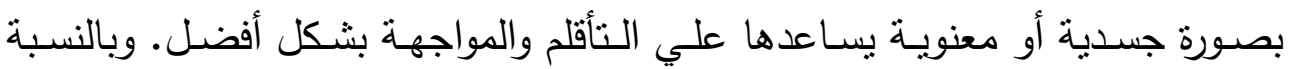
للشخصية المازوخية فهي تعيش من خلا الاعتقاد بأن تعذيب الآخرين لها سواء

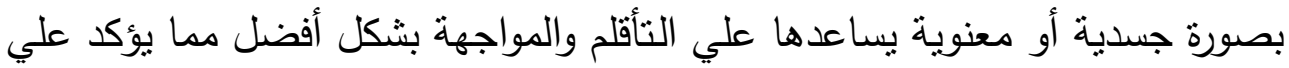
عدم وجود معتقدات الوعي أو الثعور بالذات لدي اضطرابات الثخصية السابقة. 


\section{المراجع}

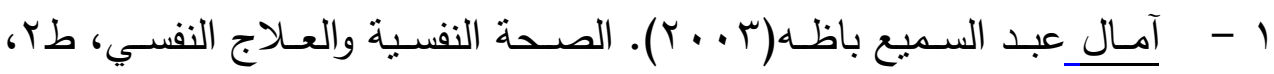
القاهرة، مكتبة الأنجلو المصرية.

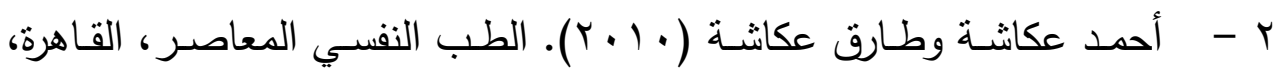
مكتبة الأنجلو المصرية.

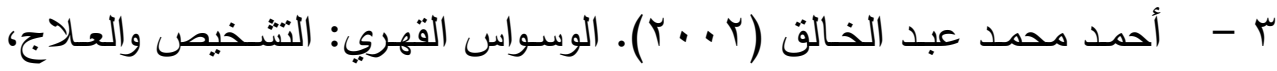
مطبوعات جامعة الكويت، مجلس النشر العلمي، لجنة التأليف والتعريب

$$
\text { والنشر م }
$$

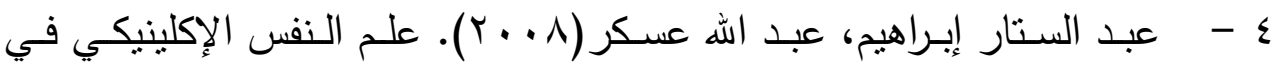
ميدان الطب النفسي، طء، القاهرة، مكتبة الأنجلو المصرية.

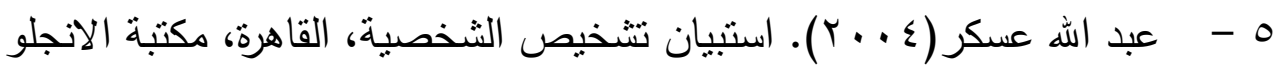

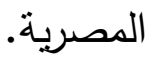

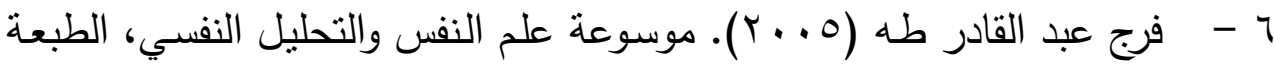
الثانية، القاهرة ، دار غريب.

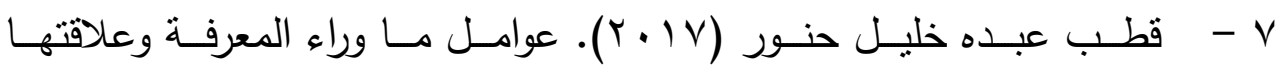
باضطرابي فقدان الثـهية العصبي والثره العصبي لدي طالبات الجامعة،

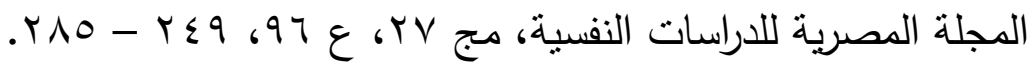

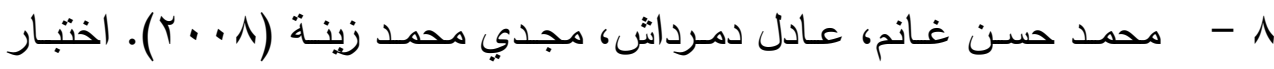
اضطرابات الثخصية، دار غريب، القاهرة.

9 - A.P.A "American psychiatric association" (2013). Diagnostic and statistical manual of mental disorders, (5thedTR), Washington, DC, London, England.

10 - Callesen, P., Jensen, A. B., \& Wells, A. (2014). Metacognitive therapy in recurrent depression: a case replication series in Denmark. Scandinavian journal of psychology, 55(1), 60-64.

11 - Dimaggio G, Procacci M, Nicol G, Popolo R, Semerari A, Carcione A, Lysaker H;(2007). Poor Metacognition in Narcissistic and 
Avoidant Personality Disorders: Four Psychotherapy Patients Analysed using the Metacognition Assessment Scale. Clinical Psychology \& Psychotherapy, 14(5), 386-401.

12 - Hjemdal, O., Hagen, R., Nordahl, H. M., \& Wells, A. (2013).

Metacognitive therapy for generalized anxiety disorder: nature, evidence and an individual case illustration. Cognitive and Behavioral Practice, 20(3), 301-313.

13 - Hjemdal, O., Stiles, T., \& Wells, A. (2013). Automatic thoughts and meta-cognition as predictors of depressive or anxious symptoms: a prospective study of two trajectories. Scandinavian journal of psychology, 54(2), 59-65.

14 - Huntley, C. D. \& Fisher, P. L. (2016). Examining the role of positive and negative metacognitive beliefs in depression. Scandinavian Journal of Psychology, 57, 446 - 452.

15 - Maher-Edwards, L., Fernie, B. A., Murphy, G., Wells, A., \& Spada, M. M. (2011). Metacognitions and negative emotions as predictors of symptom severity in chronic fatigue syndrome. Journal of Psychosomatic Research, 70(4), 311-317.

16 - Matthews,G.(2015). Advancing the theory and practice of metacognitive therapy: a commentary on the special issue. Cogn. Ther. Res. 39, 81-87.

17 - Moghadam, N. S., Abolmaali, K., \& Mojtabaie, M. (2014). Comparison of Meta-Cognitive Beliefs with Regard to Depressed, Obsessive-Compulsive and Normal Individuals. Health, 6(13), 1662-1668.

18 - Outcalt J, Dimaggio G, Popolo R, Buck K, Chaudoin K, Kukla M, Olesek K, Lysaker P;(2016). Metacognition moderates the relationship of disturbances in attachment with severity of borderline personality disorder among persons in treatment of substance use disorders, Comprehensive Psychiatry, 64, 22-28.

19 - Palmier J, Dunn G, Morrison A. P, Lewis S.W;(2011). The Role Of Metacognitive Beliefs In Stress Sensitisation, Self-Esteem Variability, And The Generation Of Paranoia, Cognitive Neuropsychiatry, 16 (6), 530-546.

20 - Semerari A, Pellecchia G, Carcione A, Nicol G, Pedone A,(2014). Metacognitive Dysfunctions In Personality Disorders: Correlations With Disorder Severity And Personality Styles, Journal of Personality Disorders, 28(6), 751-766. 


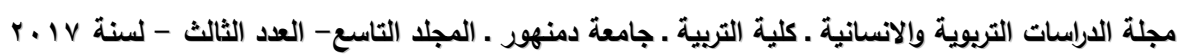

21 - Valiente C, Prados J.M, Diego G, Filiberto F;(2012). Metacognitive Beliefs And Psychological Well-Being In Paranoia And Depression, Cognitive Neuropsychiatry, 17 (6), 527-543.

22 - Valizade, M., Hasanvandi, S., Honarmand, M. M., \& Afkar, A. (2013). Effectiveness of Group Metacognitive Therapy for Student's Metacognitive Beliefs and Anxiety. Procedia-Social and Behavioral Sciences, 84, 1555-1558.

23 - Vann, A., Strodl, E., \& Anderson, E. (2013). Thinking about internal states, a qualitative investigation into metacognitions in women with eating disorders. Journal of eating disorders, 1( 22), 1-11.

24 - Wells, A. (2009). Metacognitive Therapy for Anxiety and Depression, Guilford Publications, New York, U.S.A.

25 - Wells, A., Fisher, P., Myers, S., Wheatley, J., Patel, T., \& Brewin, C. R. (2012). Metacognitive therapy in treatment-resistant depression: A platform trial. Behaviour research and therapy, 50(6), 367-373.

26 - Wenn, J., O'Connor, M., Breen, L. J., Kane, R. T., \& Rees, C. S. (2015). Efficacy of metacognitive therapy for prolonged grief disorder: protocol for a randomised controlled trial. BMJ open, 5(12), 1-10. 
عوامل ما وراء المعرفة ودورها في اضطرابات الشخصية د. قطب عبده خليل حنور د. محمود مغازي العطار 